OPEN ACCESS

Edited by: Markus Stoffel,

Université de Genève, Switzerland

Reviewed by:

Marta Domínguez Delmás, University of Amsterdam, Netherlands Katarina Cufar,

University of Ljubljana, Slovenia

*Correspondence:

Willy Tegel

tege/@dendro.de

Specialty section:

This article was submitted to

Paleoecology,

a section of the journal

Frontiers in Ecology and Evolution

Received: 27 November 2021

Accepted: 04 January 2022

Published: 16 February 2022

Citation:

Tegel W, Muigg B, Skiadaresis G, Vanmoerkerke J and Seim A (2022)

Dendroarchaeology in Europe.

Front. Ecol. Evol. 10:823622.

doi: 10.3389/fevo.2022.823622

\section{Dendroarchaeology in Europe}

\author{
Willy Tegel ${ }^{1,2 *}$, Bernhard Muigg ${ }^{1,3}$, Georgios Skiadaresis ${ }^{4}$, Jan Vanmoerkerke ${ }^{5}$ and \\ Andrea Seim ${ }^{2,6}$
}

${ }^{1}$ Amt für Archäologie, Kanton Thurgau, Frauenfeld, Switzerland, ${ }^{2}$ Chair of Forest Growth and Dendroecology, Institute of Forest Sciences, Albert Ludwig University of Freiburg, Freiburg, Germany, ${ }^{3}$ Chair of Forest History, Institute of Forest Sciences, Albert Ludwig University of Freiburg, Freiburg, Germany, ${ }^{4}$ Chair of Silviculture, Faculty of Environment and Natural Resources, University of Freiburg, Freiburg, Germany, ${ }^{5}$ Regional Archaeological Service, Directions Régionales des Affaires Culturelles, Châlons-en-Champagne, France, ${ }^{6}$ Department of Botany, University of Innsbruck, Innsbruck, Austria

Human evolution was strongly related to environmental factors. Woodlands and their products played a key role in the production of tools and weapons, and provided unique resources for constructions and fuel. Therefore wooden finds are essential in gaining insights into climatic and land use changes but also societal development during the Holocene. Dendroarchaeological investigations, based on tree rings, wood anatomy and techno-morphological characteristics are of great importance for a better understanding of past chronological processes as well as human-environment-interactions. Here we present an overview of the sources, methods, and concepts of this interdisciplinary field of dendroarchaeology focusing on Europe, where several tree-ring chronologies span most of the Holocene. We describe research examples from different periods of human history and discuss the current state of field. The long settlement history in Europe provides a myriad of wooden archeological samples not only for dating but also offer exciting new findings at the interface of natural and social sciences and the humanities.

Keywords: tree rings, dendrochronology, land use, paleoecology, wood anatomy, wood technology

\section{INTRODUCTION}

\section{Importance of Wood}

Since the beginning of mankind people have extracted and processed plant resources. Human cultural development has relied on wood, in particular, for producing tools, building constructions but also as the primary source of energy. Archaeological research, however, has a strong focus on non-biodegradable sources. This is reflected in the so-called three-age system for the rough classification of humans' pre-history into three main time-periods: the Stone Age, the Bronze Age and the Iron Age, which was established by Thomsen (1836) and is still widely used in modern archeology (Kipfer, 2000). This prevailing focus can be explained by the better preservation conditions of inorganic material. Nevertheless, wood has played an equally, if not the most important role as a raw material in all epochs up to our present time. The key role of wood as an energy source only started to diminish in the latest phase of human history, when fossil fuels became widely accessible as alternative sources of energy (Freese, 2003). The increasing use of coal, petroleum and natural gas during the modern period created the preconditions for the industrial development during the 19th century and accelerated considerably with modern chemistry at the beginning of the 20th century. As a result, forest utilization lost much of its importance since 
modern societies of the 19th and 20th century allegedly have been relieved from depending on renewable forest resources (Ritchie and Roser, 2017). For a great part of human history, however, the development of societies was dominated by their interaction with woodlands, since they relied on forest products for most aspects of their everyday life (Willerding, 1996).

Sophisticated supply strategies for woodland resources have been developed over time and have substantially contributed to the shaping and advance of societies and cultures. In particular, trees had numerous functions as a valuable and diverse source for construction material, fuelwood, raw material (e.g., for tools, weapons, furniture, jewelry), food (fruits, seed, fodder), tanning and coloring agent, fiber production (e.g., clothing, ropes, nets), and for resin and pitch production (Andraschko, 1996).

\section{Dendroarchaeology}

Dendroarchaeology is the study of historical and archaeological wood from various contexts and functions (Figure 1). These investigations are based on tree rings, wood anatomy and techno-morphological characteristics. With the application of dendrochronology [from ancient Greek: dendron (tree), khronos (time), -logia (the study of)], each tree ring can be precisely dated to a calendar year since annual variations in ring widths are strongly linked to annual variations in weather conditions, which allows for the alignment of ring-width patterns of different trees within a region (Douglass, 1909) (see section "Crossdating" for details on the method).

Comprehensive dendroarchaeological studies combining archeological and dendrochronological methods and data allow valuable insights into the chronological development of cultural processes, the history of ancient woodworking and construction techniques as well as into former forest utilizations and environmental conditions.

Dendroarchaeology, as a relatively young branch of research in archaeology, found its first application in Europe during the 1940s in an interdisciplinary effort to systematically investigate wooden finds from archaeologically excavated pre-historic wetland settlements of the northern pre-Alpine lakes (Rump, 2011). The combination of methods from botany, forestry, timber industry and archaeology helped to optimally process the delicate organic wooden finds (Bräker et al., 1979; Broda and Hill, 2021). For the first time, it was possible to record features and structures as well as the settlement dynamics of prehistoric lakeside settlements with chronological precision (Huber, 1941). As a consequence of the ground-breaking results, wooden remains gained greater attention in archaeological research.

\section{History of Dendrochronological Research}

The first description that trees form tree rings was done by Theophrastus (c. 371 - c. 287 BCE), a Greek philosopher and naturalist. Leonardo da Vinci (1452 - 1519 CE), followed by Montaigne (1533 - $1592 \mathrm{CE})$, were likely the first to recognize that these patterns occur in an annual sequence. The fact that tree rings are suitable for determining the life span of a tree became more generally known in the course of the 17 th and 18th centuries, but it was not until the end of the 19th century that Arthur Freiherr von Seckendorff-Gudent began to "overlap" tree-ring sequences of different trees (Wimmer, 2001). Other applications of tree-ring analysis included the evaluation of how tree growth is affected by pollution (Stoeckhardt, 1871). The first attempt to examine the association between tree growth and climate was made by the Dutch astronomer Jacobus C. Kapteyn who matched tree-ring sequences from regions in the Netherlands and Germany (Kapteyn, 1914; Stallings and Schulman, 1937). However, Andrew E. Douglass, an American astronomer defined the science of dendrochronology, as he aimed at using tree rings to demonstrate a connection between the earth's climate and the 11-year cycle of sunspots (Douglass, 1920). By using the method of crossdating (Figure 2 and see also section "Crossdating"), Douglass was also able to determine the age of dead and decayed tree samples and in 1929, he established a continuous 1229-year long tree-ring chronology extending back to $700 \mathrm{CE}$. For the first time in history it was possible to date timber from archaeologically excavated cliff dwellings from the 13th century at Tsegi Canyon, Mesa Verde, and Canyon de Chelly with annual precision (Douglass, 1935). Inspired by Douglass' success, several researchers from Russia, Scandinavia and Germany independently studied European tree species. The further development of dendrochronology in Europe is strongly connected with the pioneering work of the Austrian botanist Bruno Huber, who initiated research on tree rings at the former Royal Saxon Academy of Forestry in Tharandt, Germany, in the 1930s (Eckstein and Wrobel, 1983; Rump, 2011). While Douglass used extreme wide and narrow rings to cross date, Huber adjusted Douglass' method by measuring and plotting each ring of the tree, owing to the fact that trees from temperate zones show less pronounced year-to-year variability than trees from semiarid zones (Eckstein and Pilcher, 1990). As early as 1941, Huber used this method to date several archaeological sites in eastern, northwestern, and southern Germany (Huber, 1941; Rump, 2011). Huber's successful dating of the Bronze Age palisades at Wasserburg Buchau, southwestern Germany, marked the beginning of modern dendroarchaeology in Europe (Huber and Holdheide, 1942).

The increasing amount of dendrochronologically dated wood samples enabled further studies including the establishment of the radiocarbon calibration curve (Huber and Jazewitsch, 1958). By successfully dating three Neolithic settlements in eastern Switzerland (Thayngen Weier, Burgäschisee Süd, and Burgäschisee Südwest), Huber established their chronological parallelism and proved for the first time that the so-called Pfyn and Cortaillod cultures (ca. 3900-3500 BCE) had coexisted at the same time (Huber et al., 1963). Furthermore, Huber and his team worked on the development of reference tree-ring width chronologies for central Europe, for example, the first and well-replicated 1000-year long oak chronology for Hesse (central Germany) (Huber, 1963; Huber and Giertz-Siebenlist, 1969). This pioneering work was accompanied by further initial dendroarchaeological investigations mainly in northern parts of Europe (e.g., Kolchin, 1962; Bauch, 1968). The German dendrochronologist Ernst Hollstein played a pivotal role in further implementing dendrochronology in Europe. Since 1960, 

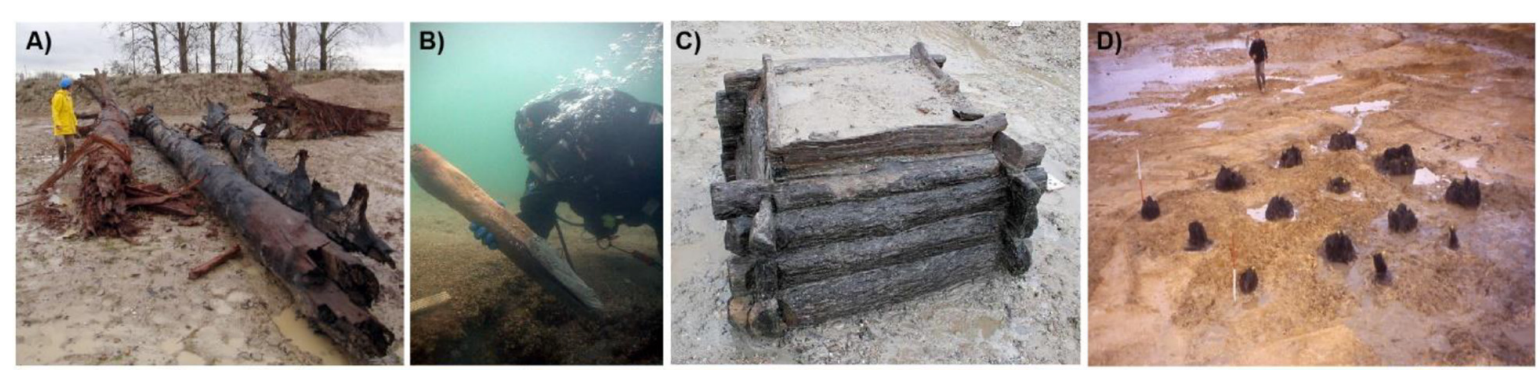
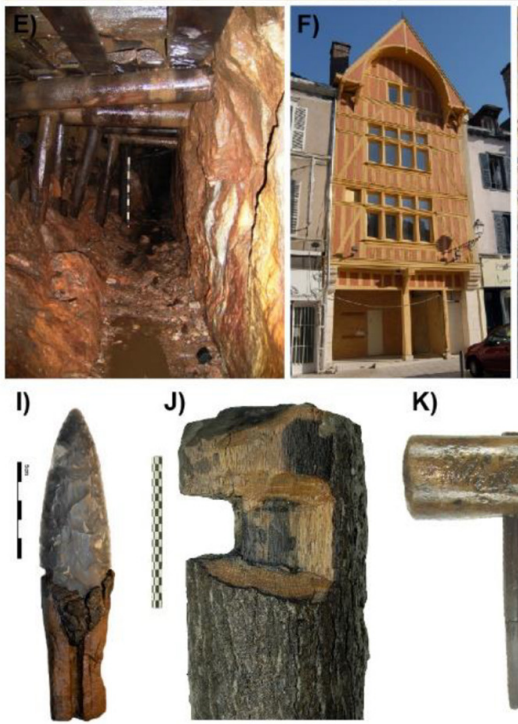

K)

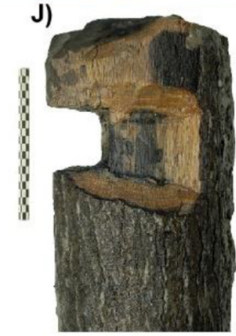

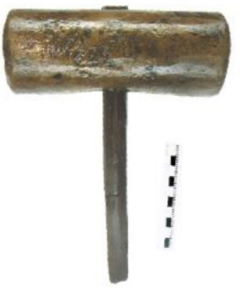

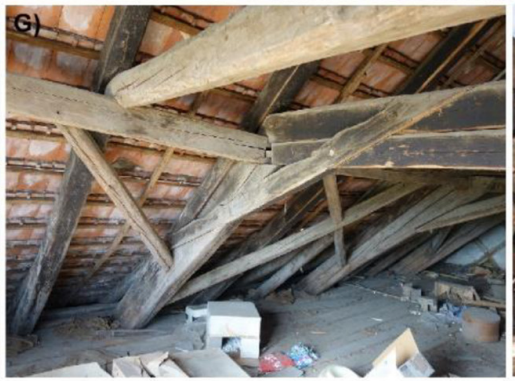

L)

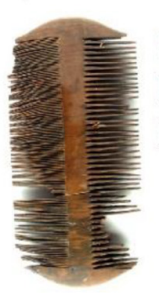

M)

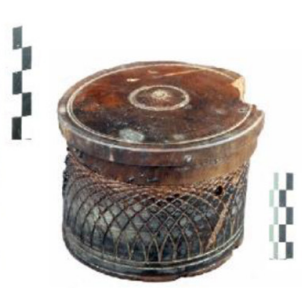

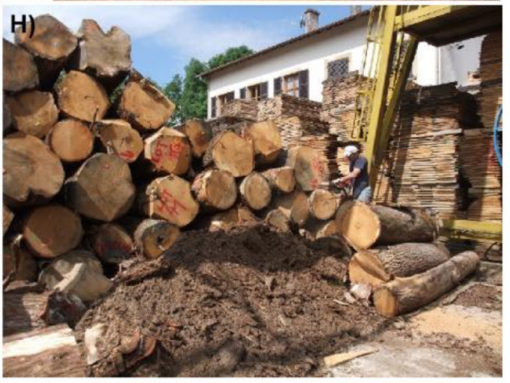
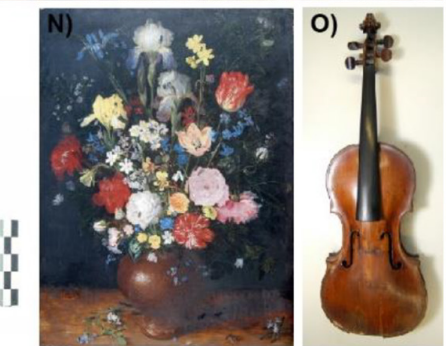

FIGURE 1 | Wood sources for dendroarchaeological research: (A) Subfossil trees from a gravel pit in the Upper Rhine Valley (Leutenheim, France). (B) Neolithic pile excavated underwater in Oehningen-Orkopf, Lake Constance, Switzerland. (C) Water well lining from the Late Bronze Age, excavated in Erstein, France. (D) Post foundation of a Roman building in Vendresse, France. (E) Medieval silver mining gallery in the Black Forest (Schauinsland, Germany). (F) Half-timbered house in Troyes, France. (G) Late medieval roof truss in Langenrickenbach, Switzerland. (H) Modern sawmill in Many, France. (I) Neolithic knife with flint blade and wooden handle from Allensbach, Germany. (J) Late Bronze Age construction timber from Erstein, France. (K) Late Iron Age wooden hammer from Saverne, France. (L) Roman comb and (M) box from Troyes, France. (N) Modern painting and (O) violin.

he sampled living and historical material in western Germany, France and Switzerland and established a 2500-year long oak treering width chronology (Hollstein, 1967, 1980; Rzepecki et al., 2019). Moreover, Hollstein not only introduced wood physical and technological characteristics to determine the time of tree felling, he also investigated the relationship of heartwood and sapwood rings in oaks and thus, established the commonly applied sapwood statistics, enabling more precise estimations of oak felling dates (Hollstein, 1965).

After the death of Bruno Huber, his former research associate Bernd Becker continued his work at the University of Stuttgart-Hohenheim (Germany). He further extended the existing chronologies with a strong focus on subfossil trees, deposited in fluvial gravel, and developed millennia-long treering chronologies for southern Germany that covered most of the Holocene (Becker, 1982). His tree-ring chronologies still provide a crucial basis for dendroarchaeological and paleo-environmental studies in central Europe (Friedrich et al., 2004). Other millennia-long tree-ring width chronologies have also been developed since the late 1970s and 1980s, for example by Pilcher (1976), Baillie (1977), Pilcher et al.
(1984), Leuschner and Delorme (1988), and Kuniholm (1994, 1996) which has led to a growing interest of archaeologists in this novel and high-precision dating method (Bannister and Robinson, 1975).

While Hollstein also worked with wood anatomical features, it was the Swiss dendrochronologist Fritz $\mathrm{H}$. Schweingruber who provided the first wood anatomical atlas in three languages, a standard reference for wood identification of central European tree species (Schweingruber, 1978). Moreover, he published a first perspective on the significance of prehistoric wood samples for both archaeological and vegetation scientific studies (Schweingruber, 1976). Fundamental conceptual works for the application of dendrochronology in archaeological and (paleo)ecological research were published in the early 1980s, e.g., by Baillie (1982) and Schweingruber (1983), creating the basis for the practical implementation of tree-ring studies on archaeological wooden finds. Dendrochronology became a standard method applied in archaeological studies during the 1980s, constituting the onset of modern dendroarchaeology in various European countries (Eckstein and Wrobel, 1983). 


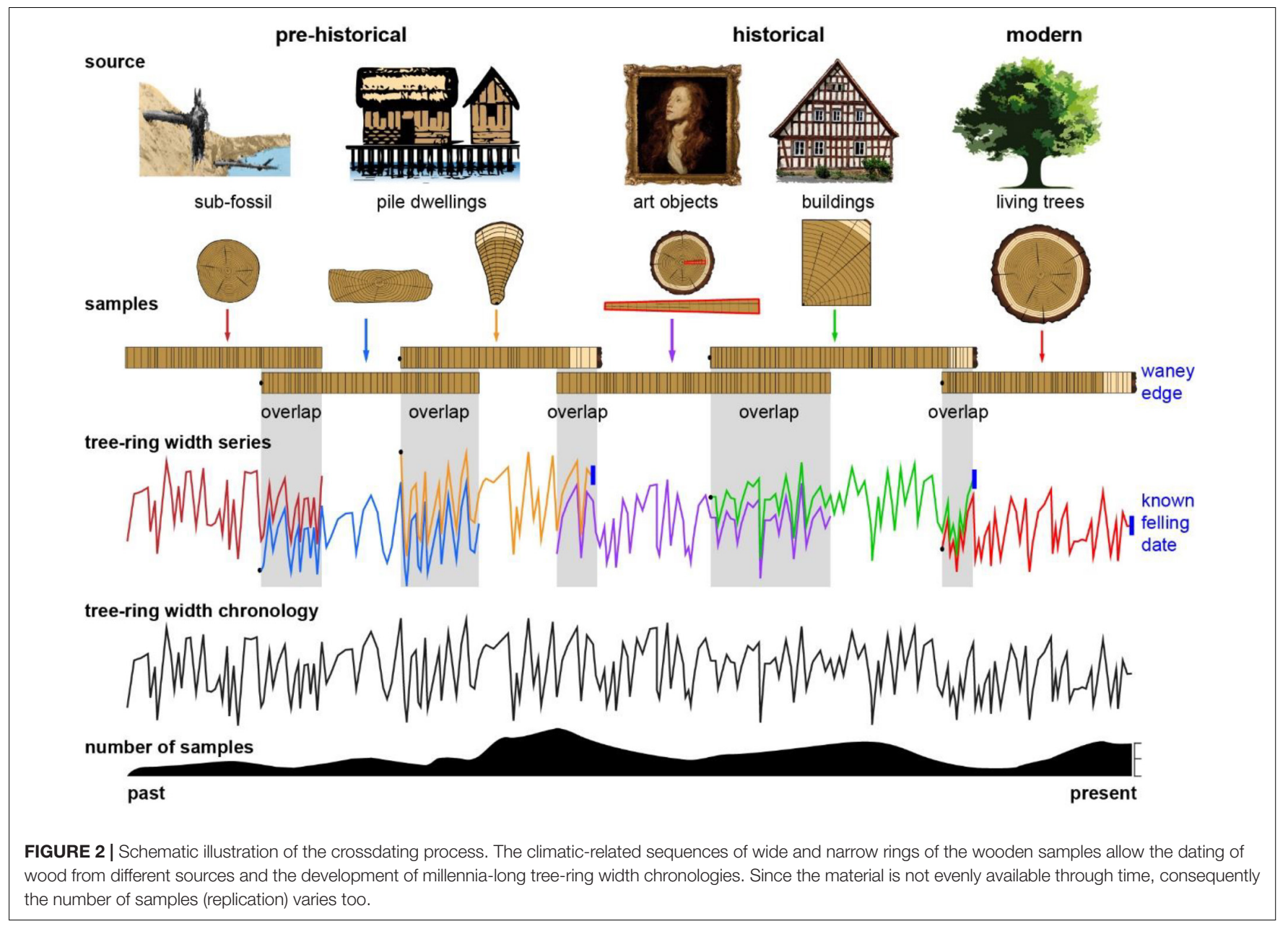

This development led to the establishment of more dendroarchaeological laboratories across Europe. During this time, first large-scale archaeological projects for different periods implemented the newly established discipline. To mention only a few examples for pre-historic times, on circum-alpine lakes in France, Germany, Italy, Switzerland and Slovenia ${ }^{1}$, for Iron Age Biskupin, Poland (Reynolds, 1985), and for medieval times in Dorestadt, The Netherlands (van Es and Verwers, 1980), Mikulčice, Czechia (Dvorská et al., 1999), Hedeby and Lübeck, Germany (Eckstein, 1978). In the context of these projects, numerous new laboratories have been founded, frequently by archaeologists who started using dendrochronology (Bernard, 1998). As a consequence, the focus on archaeological research questions intensified toward wood utilization, species selection, resource management and the technical and architectural development of settlements (e.g., Billamboz, 1988). The advances of dendrochronology provoked further interest from the fields of historical building research, however, with a stronger focus on dating and provenancing, and mainly performed by numerous newly founded laboratories all over Europe (e.g., Kuniholm and Striker, 1990; Eißing, 2005; Épaud, 2007; Hoffsummer, 2009;

${ }^{1}$ https://whc.unesco.org/en/list/1363/
Kyncl, 2016; Domínguez-Delmás et al., 2018). Over the last decades, vast amounts of dendroarchaeological data have been collected from countless archaeological sites and historical constructions as well as from natural depositions in paleochannels and from living trees all over Europe. The great number of laboratories and their interaction accelerated the development of well-replicated centennial to millennia-long tree-ring chronologies for various European regions, placing Europe in a unique position compared to the rest of the globe (Becker et al., 1985).

However, the state of dendroarchaeological research varies greatly among different countries and regions due to different research foci, political settings and administrative structures.

\section{MATERIAL}

\section{Conditions and Forms of Preservation}

Wood is an organic matter, easily biodegradable by bacteria and fungi and their enzymes (Blanchette et al., 1990; Pedersen et al., 2020), but under special conditions wooden structures and objects can be preserved for a long time (Figure 3). One such case of wood preservation is the lack of moisture in 

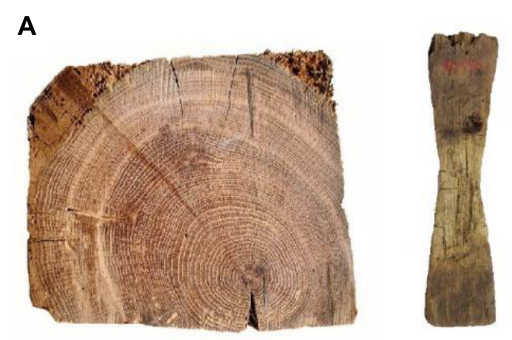

C

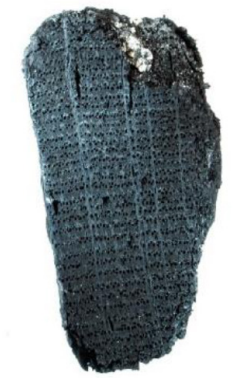

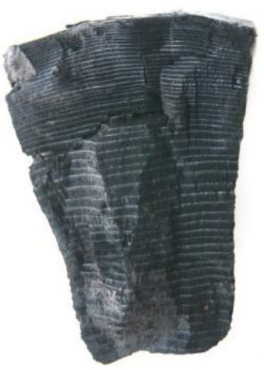
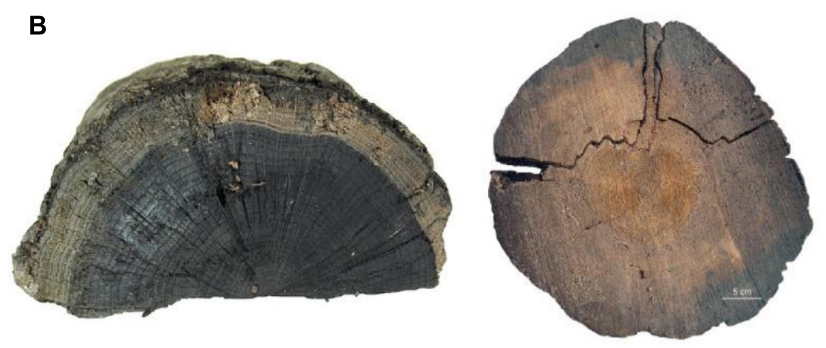

D
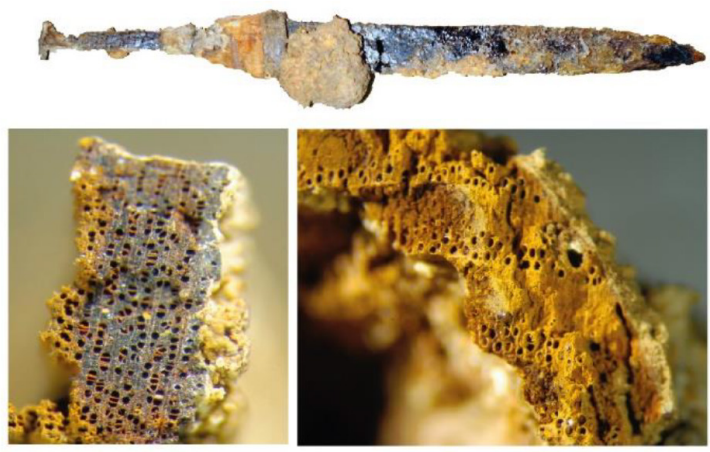

FIGURE 3 | Different types of wood preservation. (A) Dry preserved wood from scaffolding timber from the cathedral Notre-Dame de Reims, France (1211 CE, Tegel and Brun, 2008) and the "pagan wall" on Mont Sainte-Odile, Ottrott, France (7th century CE, Tegel and Muigg, 2015). (B) Wood preserved under wet conditions from a late bronze age well made of oak in Erstein, France (1208 BCE) and from a preboreal pine from gravel quarry at Pont-sur-Seine, France $\left({ }^{14} \mathrm{C}\right.$ $11000 \pm 60$ BP). (C) Charcoal from oak (Cuperly, France, 133 BCE) and silver fir (Schauinsland, Germany, 1545). (D) Wood (alder (Alnus sp.; left) and ash (Fraxinus excelsior; right) preserved through mineralization processes on early medieval weapons, found as grave goods in burials (Tegel et al., $2016 a)$.

constantly dry environments. Such conditions prevail mostly in arid regions, e.g., at the Syrian site of Dura Europos, but are occasionally also found in central Europe (Tegel and Muigg, 2015; Tegel and Croutsch, 2016; Baird, 2018). Another form of wood preservation is achieved when constantly low temperatures prevent biodegradation. These preservation conditions are mainly found in permafrost soils, e.g., the Kurgan graves of Pazyryk (Russia), but also in alpine glaciers (Polosmak and Seifert, 1996; Parzinger, 2006; Nicolussi, 2009). Other forms of preservation are associated with the deposition in a biotoxic environment, for example, in the famous Hallstatt saltmines, Austria (Herzig, 2009; Reschreiter and Kowarik, 2019; Haneca and Deforce, 2020; Grabner et al., 2021), and the chemical alterations of the wood tissue through carbonization and mineralization (Chabal, 1997; Tegel et al., 2016a; Haneca and Deforce, 2020). However, the most important form of wood preservation is provided by waterlogged conditions, frequently discovered at archaeological excavations, for example in water wells and other features below the groundwater level (Kretschmer et al., 2016; Croutsch et al., 2020), from pile dwellings in lakes and bogs (e.g., Bleicher, 2009; Tarrús, 2018; Benguerel et al., 2020; Hafner et al., 2021; Pranckënaitë et al., 2021), shipwrecks at the bottom of seas, lakes and rivers (e.g., Domínguez-Delmás et al., 2013; Nayling and Susperregi, 2014; Daly et al., 2021) and paleo-channels (Pilcher et al., 1977; Becker et al., 1985; Leuschner and Sass-Klaassen, 2003; Edvardsson et al., 2016b; Figure 1). Waterlogged wooden objects can be preserved for millennia (Thieme, 1997; Tegel et al., 2012; Rybníček et al.,
2020). As wood cells and inter-cellular spaces are filled with water, freshly excavated waterlogged wooden objects display the original shape and surface. However, despite the intact surface, the cell walls are degraded, the percentage of cellulose and hemicelluloses is decreased and the proportion of lignin is increased. In this way the mechanical properties of the wood are reduced (Schweingruber, 1976; Cufar et al., 2008c; Björdal, 2012).

\section{Wood Sources}

The wooden material for dendroarchaeological analysis originates from different sources, including archaeological excavations, historic buildings, museums and private collections, natural deposits, and modern forests (Figure 1).

A great amount of samples is obtained from archaeological excavations and historical buildings. Archaeological excavations regularly unearth well-preserved wooden structures and everyday objects of past societies. Ever since the 19th century, various small to large-scale excavations have unearthed wooden objects. The quality of archaeological documentation and the treatment of these delicate finds varied greatly, depending on the timing of the excavation and the experience of the excavating personal. Improved technical standards for the treatment of archaeological sites and historical buildings were set in the second half of the 20th century, when most European countries passed legislations for heritage protection (Martin and Krautzberger, 2010). By the turn of the millennium, most European countries furthermore ratified international laws for the treatment of archaeological sites, defined by the International Committee for 
the Management of Archaeological Heritage in the Charta of Lausanne and the Charta of La Valetta (Malta) in 1989 and 1992, respectively (Hönes, 2005).

Since the beginning of modern dendroarchaeology in the 1980s, European laboratories have produced dendroarchaeological data for various regions, different species and with different chronological emphases. Within the last decades, it has become evident that areas with active and well organized departments for preventive archaeology generally show larger quantities of wooden finds than others (Laurelut et al., 2014). The same applies for other forms of physical heritage, e.g., historical buildings. The number of historical constructions and monuments studied, dated and therefore accessible for further dendroarchaeological studies strongly depends on the statutory framework and on how well-equipped and organized regional departments of heritage conservation are. Aside from historical timber, other sources of wood from historical buildings are concealed within cavities in the construction, e.g., between ceilings and floors, and occasionally studied by medieval and post-medieval archaeologists (Lohwasser, 2011; Atzbach, 2012). A special case of historical wood material is found in art objects, e.g., panel paintings, and instruments which are in most cases well-studied and safely stored in museums or private collections (Fraiture and Dubois, 2011).

Modern reference material is available from living trees in forests or recently harvested trees and is used for the development of reference chronologies and calibration with instrumental climate data to study past climate variations (e.g., Büntgen et al., 2011c; Cook et al., 2015; Tegel et al., 2020).

\section{METHODS AND CONCEPTS OF DENDROARCHAEOLOGICAL RESEARCH}

\section{Sampling and Documentation}

Dendroarchaeology combines typological analyses of surface treatments with internal features of tree growth. Size, crosssectional shape and tool marks provide information on woodworking techniques and woodland use, whereas annual growth rates allow, besides the chronological classification of wooden objects, the study of the woodland's history. Knowledge of the utilized wood species further enables syntheses on the development of construction techniques, building history and settlement dynamics. Comprehensive and consistent sampling is a necessary precondition for conclusive results of dendroarchaeological studies. The individual sampling strategy depends mostly on the different research questions that address technological as well as ecological issues and are established in close collaboration with the excavating archaeologists or conservators. Note that any valid scientific statement regarding past forest composition, resource management or wood utilization requires extensive quantities of samples (Büntgen et al., 2012). Ideally, every excavated wooden object should be entirely removed from the soil or sampled and investigated immediately after and before any conservation treatment. Therefore, waterlogged wooden objects should be generally kept in plastic wrap to prevent that cell walls break and the wood collapses due to desiccation. In situ documentation of archaeological artifacts is provided by field archaeologists. Prior to the extraction of a sample, the wooden object is cleaned, if necessary, and documented (e.g., photographed and/or by creating drawings or scans) for the study of tool marks, as distinct techno-morphological features are partially only visible after the excavation (Figure 4). Following the careful investigation of the artifact's surface, a cross-sectional sample is extracted for tree-ring analyses. Simple preparation techniques are applied to improve the visibility of annual ring boundaries. In most cases, surface treatment with razor blades or cutters is sufficient. Powdered chalk can be used to enhance the contrast of the different cell types and therefore improve visibility of tree-ring boundaries, especially for narrow rings.

Documentation of the cross-sectional shape provides important information about the size and diameter of the trees used for timber and the woodworking process, e.g., the longitudinal splitting of trunks (Figure 5). To secure this information, standardized sketch drawings are prepared. The scale used depends on the size of the wooden object, a scale of 1-5 has been proven effective in most cases (Figure 5). It must be emphasized that the point of sample extraction on the object should be selected by the dendroarchaeologist to prevent sampling in areas of disturbed tree-ring patterns such as branches, cracks, wounds, reaction wood, etc. (Schweingruber, 1976). To maximize the obtained information, samples should ideally include the full tree-ring sequence from the pith to the bark (waney edge).

In historical buildings, documenting the location of the sample on photos or architectural plans is necessary to record the context within the construction and to combine chronological and technological information (Figure 6). By experience, a minimum of 6-10 samples per structural unit are needed. With the exception of art objects (i.e., paintings and sculptures), sample collection for dendroarchaeological research is performed by sawing cross-sections or by coring samples with increment borers (Figure 6). Dendroarchaeological analyses on art objects, instruments and furniture is conducted using either invasive non-destructive methods (i.e., cleaning with a scalpel; Edvardsson et al., 2021) to non-invasive methods (e.g., X-ray computed tomography; Daly and Streeton, 2017; Domínguez-Delmás et al., 2021).

\section{Wood Anatomy}

The study of wood anatomical features is a crucial step in dendroarchaeological studies for several reasons. Firstly, the taxonomical identification based on these features, holds information of intentional species selection of past societies (Tegel and Croutsch, 2016; Tegel et al., 2016a). Secondly, it is necessary to develop species-specific master chronologies for dendrochronological dating. Thirdly, microscopic examinations of wood anatomical anomalies (e.g., frost rings, light rings or traumatic tissue) can provide important information for paleo-ecological research (Wimmer, 2002; Schweingruber, 2007). 
A
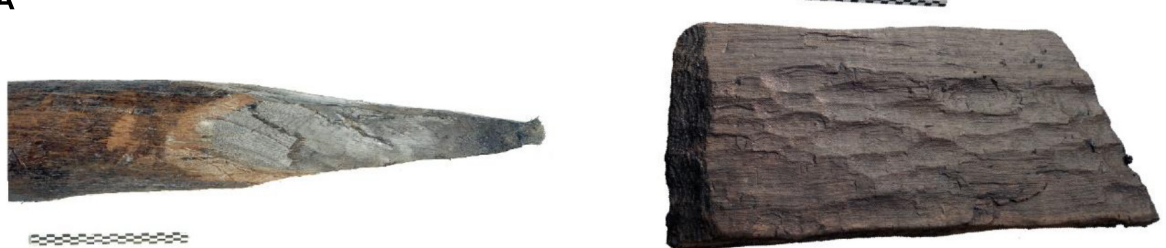

$s=z=z=z=z=z=z=z=0$

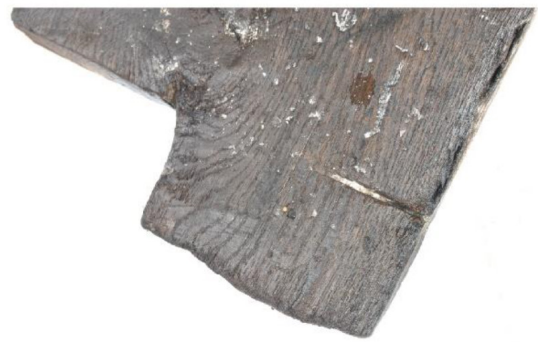

B
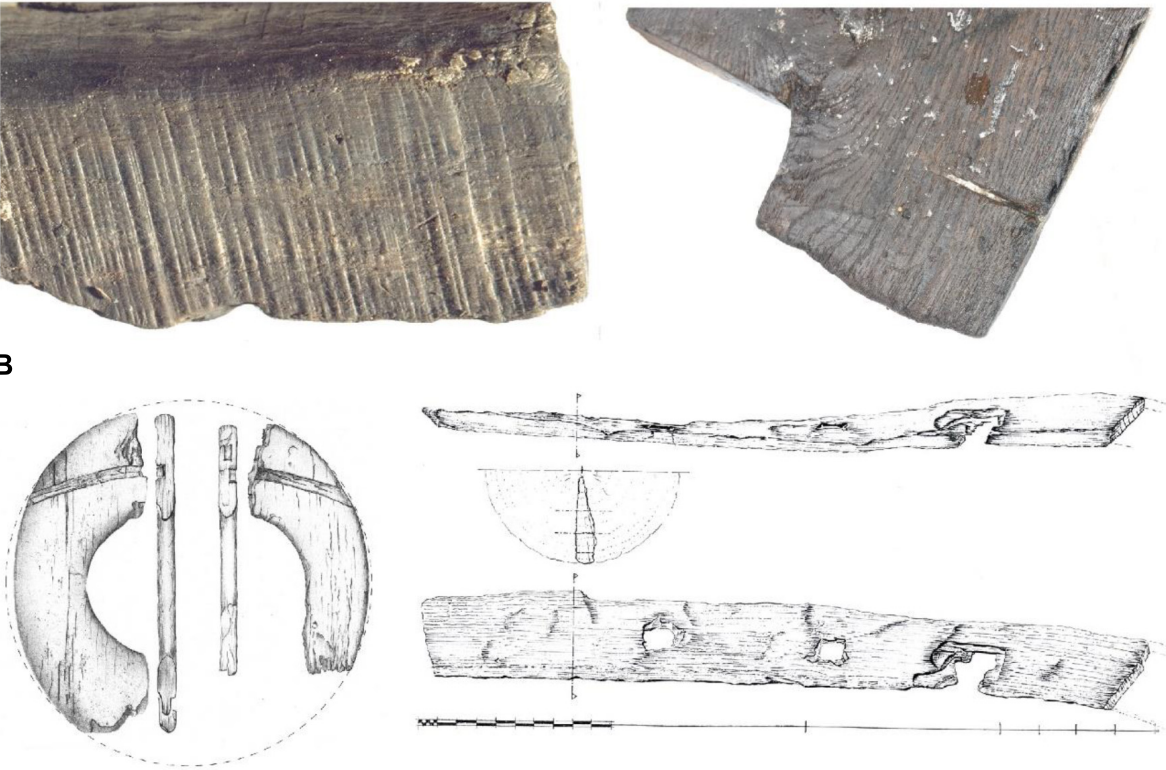

C

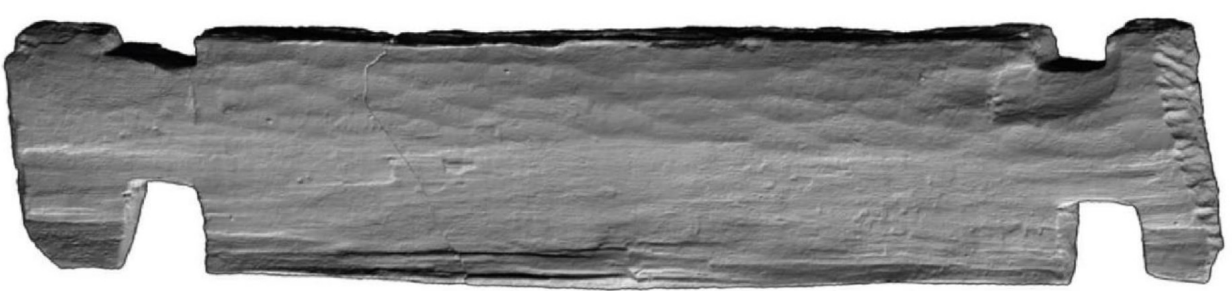

FIGURE 4 | Examples of the documentation of archaeological waterlogged wood (Rybníček et al., 2018) by (A) photos of tool marks from slashing tools (axes, adzes) and saws, (B) drawings (Tegel and Croutsch, 2016), and (C) laser scan (Tegel et al., 2012).

Wood anatomical features are studied on transverse, radial and tangential thin-sections under microscopes for taxonomical identification and to determine growth anomalies. Modern and waterlogged wood is usually investigated under a transmitted light microscope after producing thin-sections. Charcoals and mineralized wood are treated in a different way since it is usually not possible to produce thin-sections. Here, samples are broken to provide "clean" surfaces that are studied under a reflected-light microscope. Taxonomical identification can be performed using standard identification keys based on wood anatomical features (Wagenführ, 1966; Grosser, 1977; Schweingruber, 1990; Schoch et al., 2004). Distinctive features are, for example, presence of resin canals, type of rays, crossfield pits for coniferous wood and distribution and size of vessels, type of perforation plates, type of rays, type of axial parenchyma for broad-leaf wood (Schoch et al., 2004; Schweingruber, 2011). Modern equipment like digital microscopes, confocal laser scanning microscopes, improved techniques of scanning electron microscopy, multi-resolution X-ray tomography etc. (e.g., Haneca et al., 2012; Balzano et al., 2019) have significantly facilitated the identification of all categories of wood. This method enables the analyses of tiny and highly degraded samples, which are often difficult to determine by conventional microscope techniques and further provides the advantage of simultaneous photographic documentation. Non-invasive imaging techniques have been developed in recent years and offer new perspectives for the visualization of wood anatomical structures and their analysis. 
A

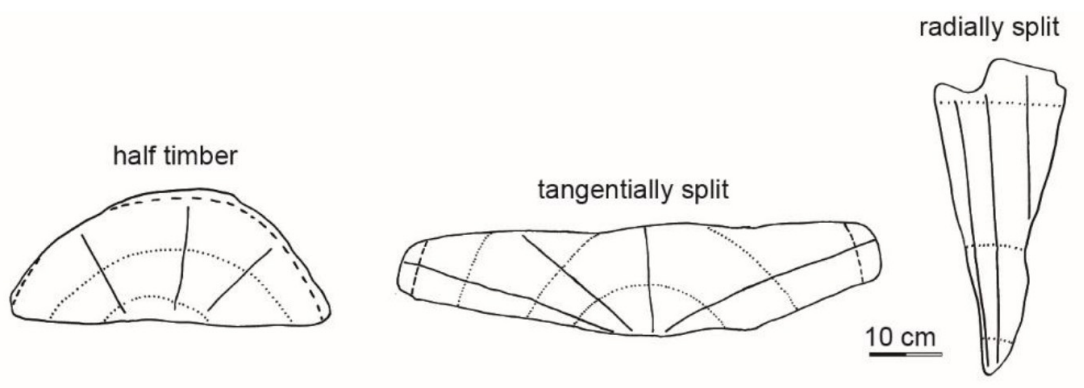

tree rings ..... rays $\longrightarrow$ sapwood --- pith $\bullet$

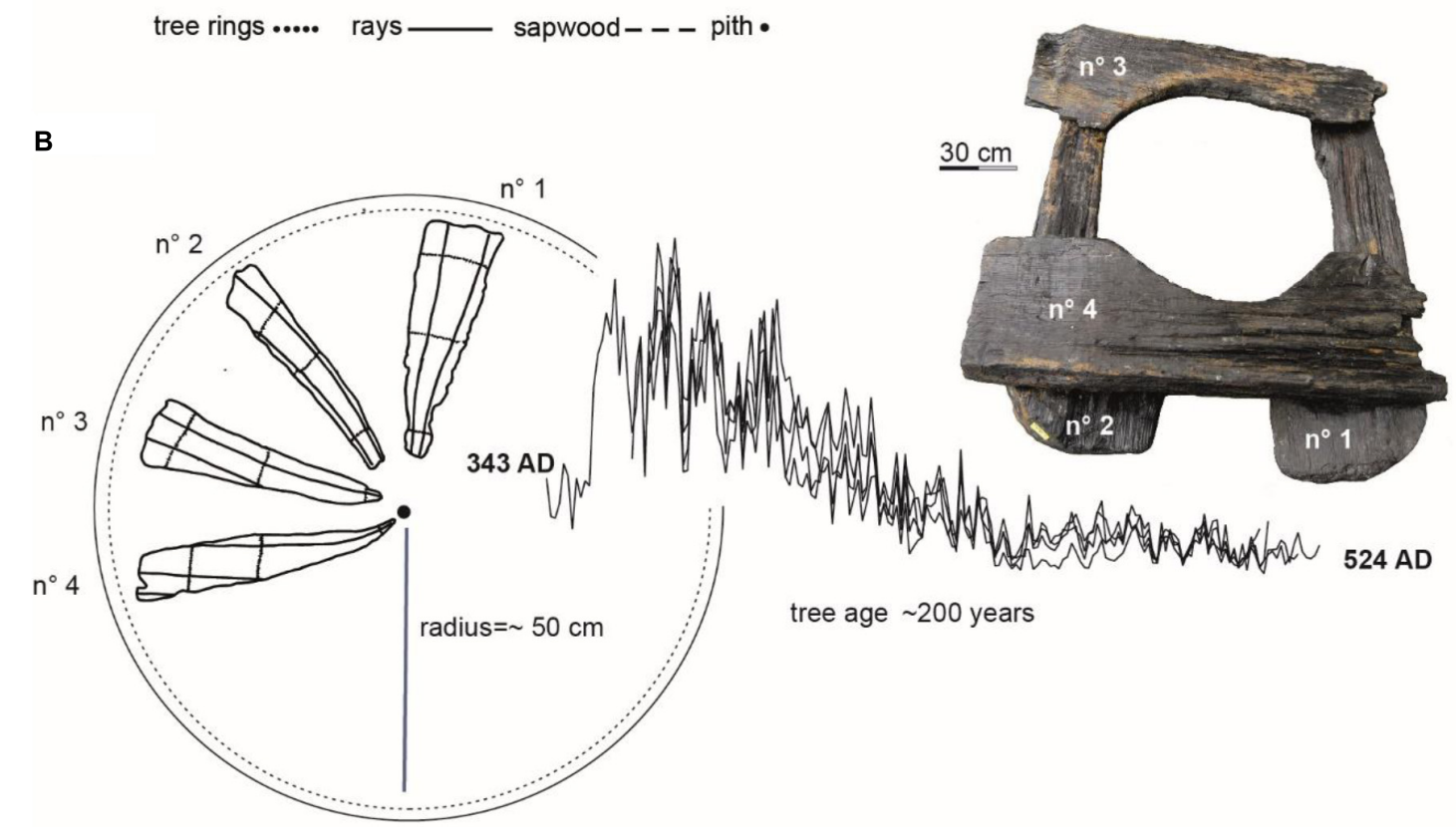

FIGURE $\mathbf{5}$ | Documentation of the used trees by (A) drawing the cross-sectional shape on a scale of 1:5 and (B) reconstruction of the origin and attribution to one individual tree trunk by using cross-sectional shapes and highly synchronous tree-ring growth patterns of the individual tree-ring curves.

\section{Crossdating}

Growth rings reflect the seasonal to annual radial growth of a tree. Such tree rings are clearly visible on the cross-section of a tree sample. By counting the annual rings, the cambial age of a tree is known. Ring widths vary due to environmental conditions, especially weather conditions, that affect the tree during wood formation but ring-width variations are also influenced by the wood species, location and position of the tree within a forest, stand dynamics, forest management practices and individual factors such as forest pests. By measuring the width of individual tree rings, a chronological sequence (treering series) is obtained that is potentially characteristic for all conspecific trees within a site or even region. This is comparable to a spatio-temporal fingerprint. The method of crossdating enables the chronological placement of a tree-ring sequence, allowing the precise identification of the year in which each tree ring was formed (Douglass, 1941). Therefore, it provides the basis for all further chronological analyses such as the precise dendrochronological dating of wooden objects. Moreover, tree rings provide a valuable archive for past environmental conditions, readable from the variation in tree-ring width and wood anatomical features, such as density fluctuations, vessel sizes, and growth anomalies (Schweingruber, 1996).

Tree-ring widths are usually measured with a precision of 0.01 or $0.001 \mathrm{~mm}$ using semi-automatic measuring tables, e.g., LINTAB $^{2}$ or VIAS ${ }^{3}$. Programs like for instance Coo Recorder ${ }^{4}$ which enable tree-ring measurement on images (manual or by automatic recognition of tree rings) are frequently used as well. The tree-ring width measurements are transformed into curves of tree-ring series showing the variation of treering widths over time allowing for their visual and statistical crossdating by using statistical parameters calculated by special programs, e.g., TSAP (Rinn, 2003) or PAST (Knibbe, 2008). Gleichläufigkeit expresses the year-to-year agreement between tree-ring series, i.e., the percentage of synchronous growth changes (Eckstein and Bauch, 1969; Buras and Wilmking, 2015). The quality of a correlation is calculated with $t$-tests transformed after Baillie and Pilcher (1973) (TBP) and Hollstein (1980)

\footnotetext{
${ }^{2}$ rinntech.de

${ }^{3}$ sciem.com

${ }^{4}$ cybis.se
} 

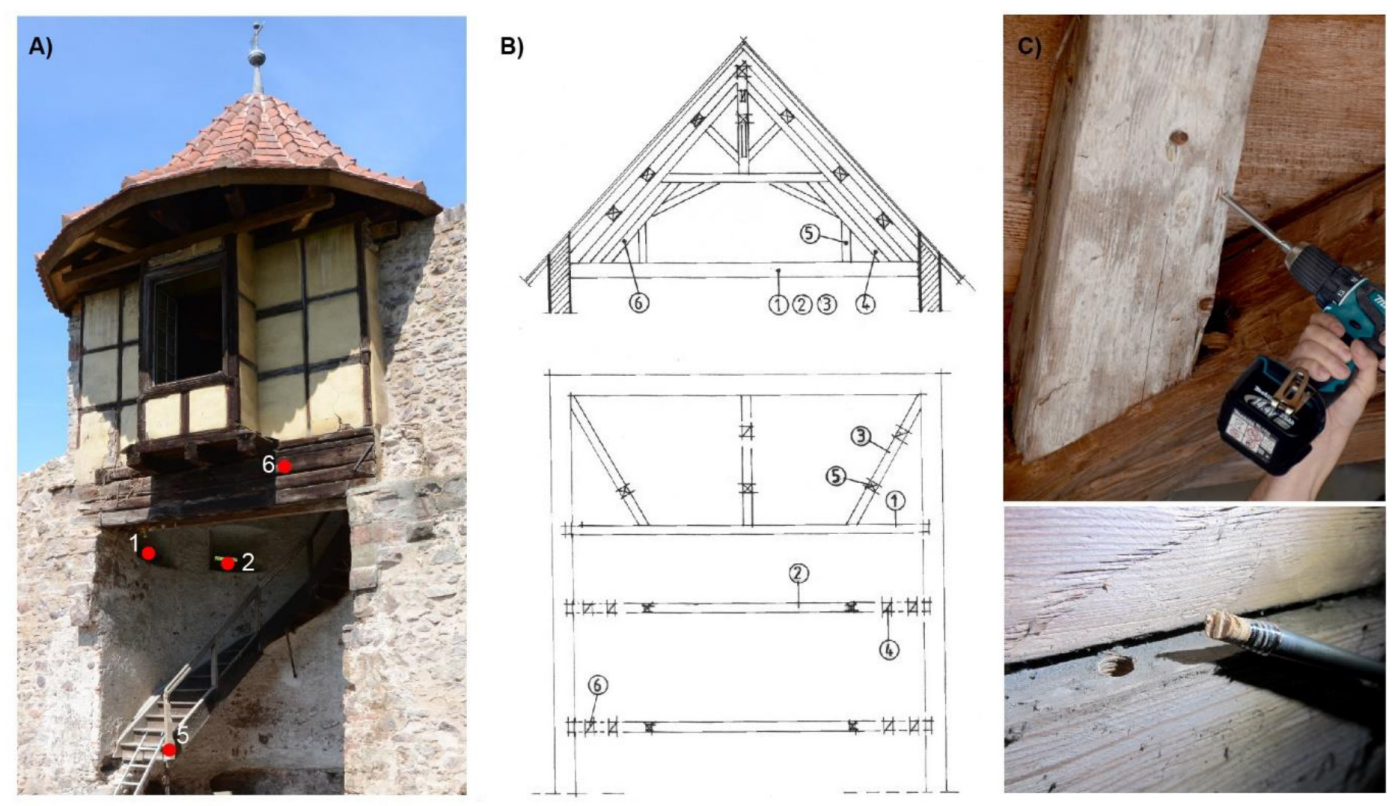

D)
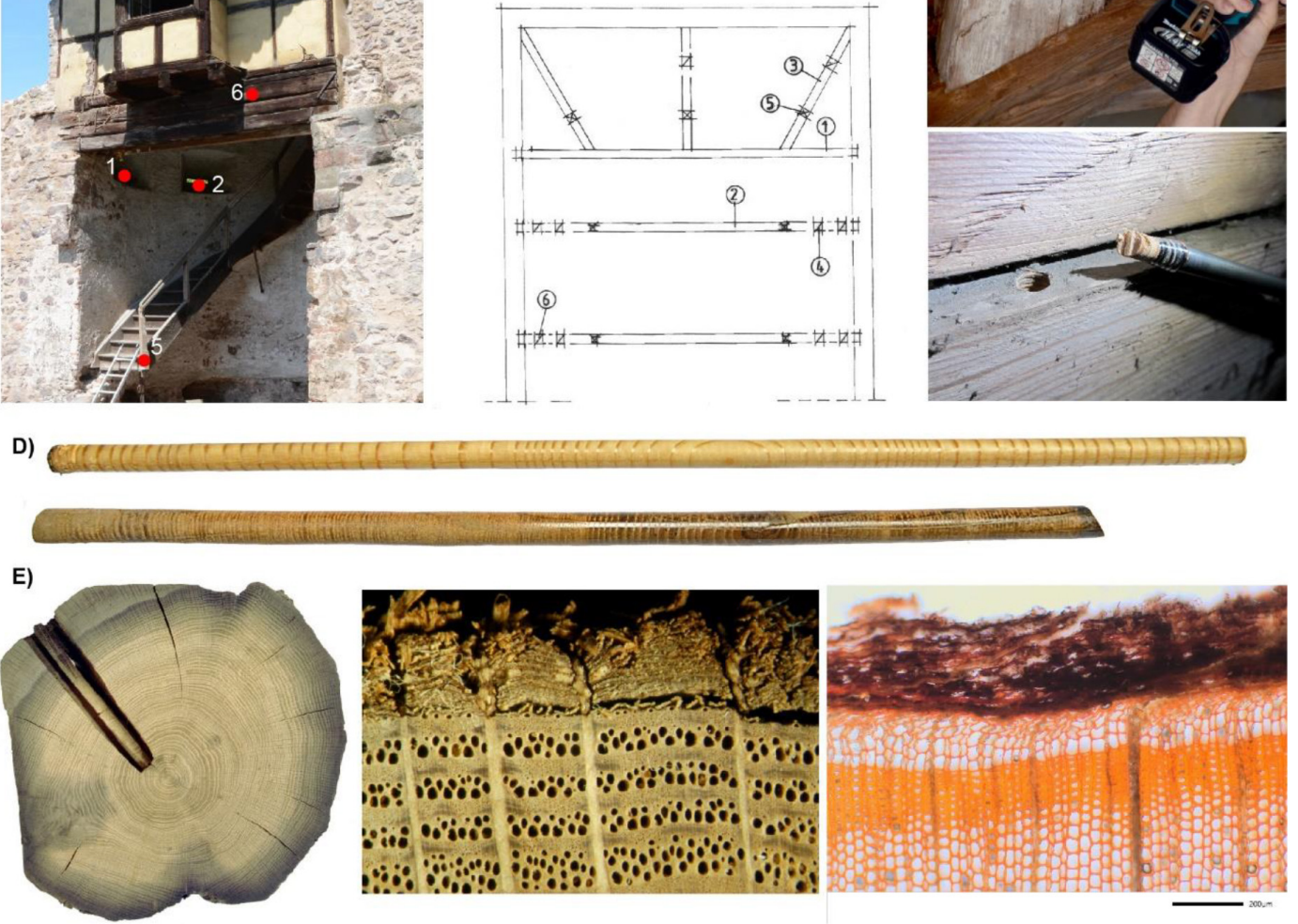

FIGURE 6 | Documentation of the location of historical timber on (A) photograph or (B) construction plans sampled with (C) increment borers and cordless drill. (D) The retrieved cores with (E) sapwood and heartwood (drilled oak disk; left) and waney edge (center and right) with parts of the bark, earlywood vessels (oak; center) and earlywood cells (pine; right) are distinguishable.

(THO) (Figure 7). The Pearson Product-Moment Correlation ( $r$ ) (Pearson, 1895), frequently used for linear correlation between two sets of data, requires additional elimination of individual growth trends (Speer, 2010). This so-called detrending method is already implied in the $t$-test calculation (TBP, THO) to highlight year-to-year variations. However, it is crucial to store the raw tree-ring width data for further investigations. For this purpose, a simple ASCII text code is the best solution, as these are readable, regardless of operating systems, and data can be easily exchanged. The most frequently used file formats are Tucson (.rwl or.tuc) and Heidelberg (.fh). We recommend the use of Heidelberg-format, as this allows to include a wide range of metadata such as the information on pith, sapwood rings, waney edge etc.

Crossdating must include all statistical approaches and the visual comparison of the measured tree-ring width sequences.
The comparison of the tree-ring pattern, i.e., the sequence of wide and narrow rings, between trees allows for the assignment of each tree ring to a precise calendar year. In this way, it is possible to build annual tree-ring width chronologies consisting of numerous tree-ring series from different sources with overlapping lifetimes of the trees (Figures 2, 7). These chronologies cover several centuries to millennia (e.g., Becker and Giertz-Siebenlist, 1970; Hollstein, 1980; Becker, 1993; Grudd et al., 2002; Friedrich et al., 2004; Baillie, 2009; Nicolussi et al., 2009; Seim et al., 2012) and serve as reference chronologies for dendrochronological dating. The quality of a reference chronology strongly depends on high sample replication, which should ideally be equally welldistributed over time. This is necessary to generate robust estimates of past growth rates and significantly improves the dating success (Büntgen et al., 2012). The spatial extent of 


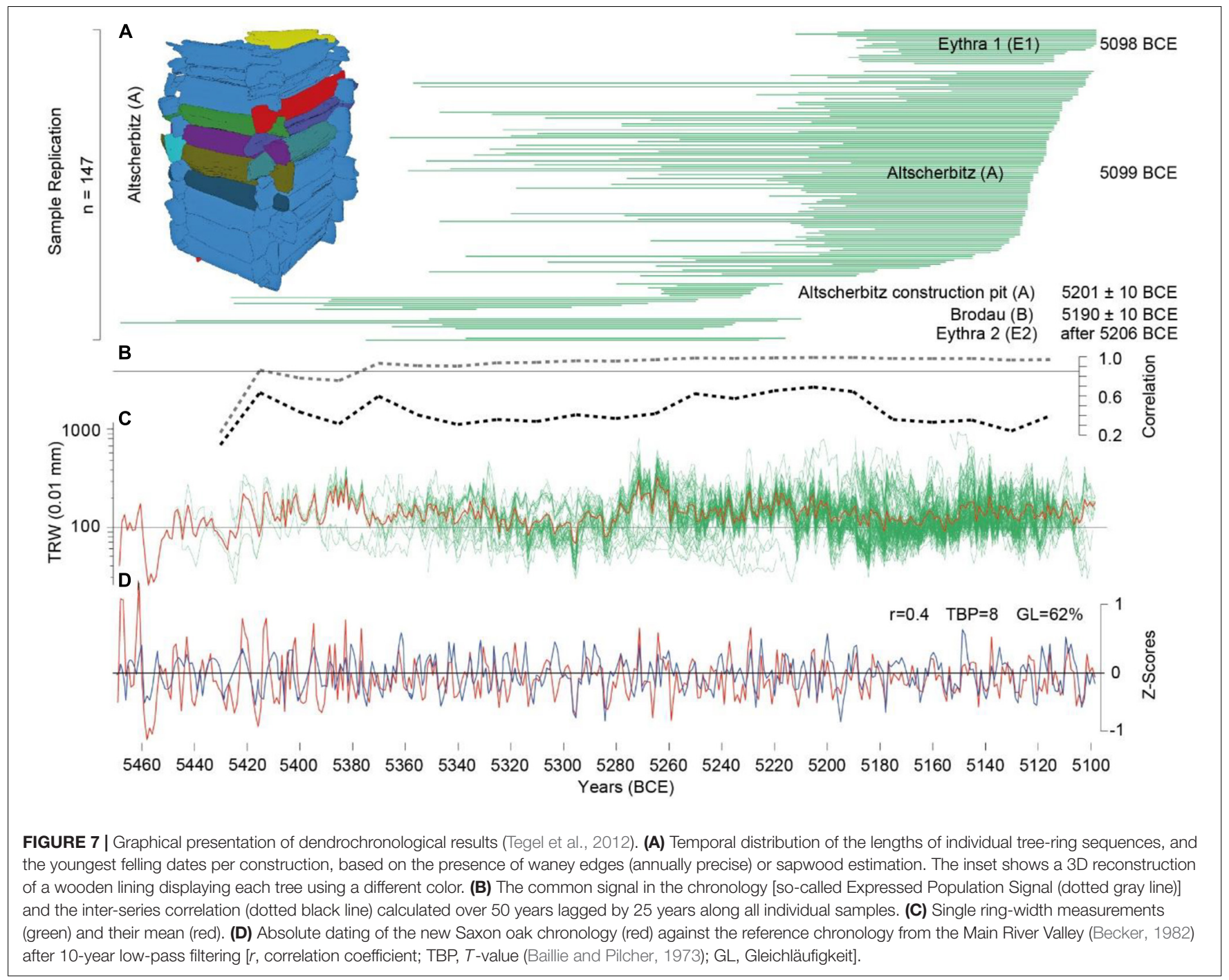

coherent growth patterns covered by a reference chronology depends on the species and their discrete physiogeographical area and thus, cannot be clearly delimited. For this reason, it has been proven useful to produce local and regional chronologies and further combine them to supra-regional chronologies especially when working on dendroarchaeological material. The use of various dendrochronological databases assists the compilation of individual chronologies which can be (re)assembled for specific research questions. Successful dating of archaeological and historical wood is usually confirmed by several independent reference chronologies. Constant improvement of the replication allows periodic updates and improvement of reference chronologies.

\section{The Accuracy of Dendrochronological Dating}

After a successful synchronization with a reference chronology, every tree ring can be attributed to a calendar year. For information on the felling date of a tree and the construction date of a wooden building, respectively, more aspects need to be considered. (1) The state of preservation of the material, (2) the tree species (e.g., for sapwood estimation), and (3) whether the outermost ring (waney edge), i.e., the last ring formed before felling, is present on the specimen.

If the waney edge is present and the stage of its development (e.g., early- or latewood formation) is observable, the exact year and season of the felling of the tree can be determined with the so-called "waney edge dating."

If the waney edge is missing but sapwood rings are present, the felling date can be estimated for species with distinct sapwood such as oak (Quercus spp.) or larch (Larix decidua) by adding an empirically obtained number of sapwood rings to the last measured sapwood ring. In this "sapwood dating", the felling date of the tree can be estimated with a precision of approximately 10 years for oaks, for example.

In the case of absent sapwood rings and waney edge (i.e., only heartwood is present), only a terminus post quem (i.e., the earliest possible felling date) can be provided. In the case of oak, a certain number of sapwood rings are added to the last measured 

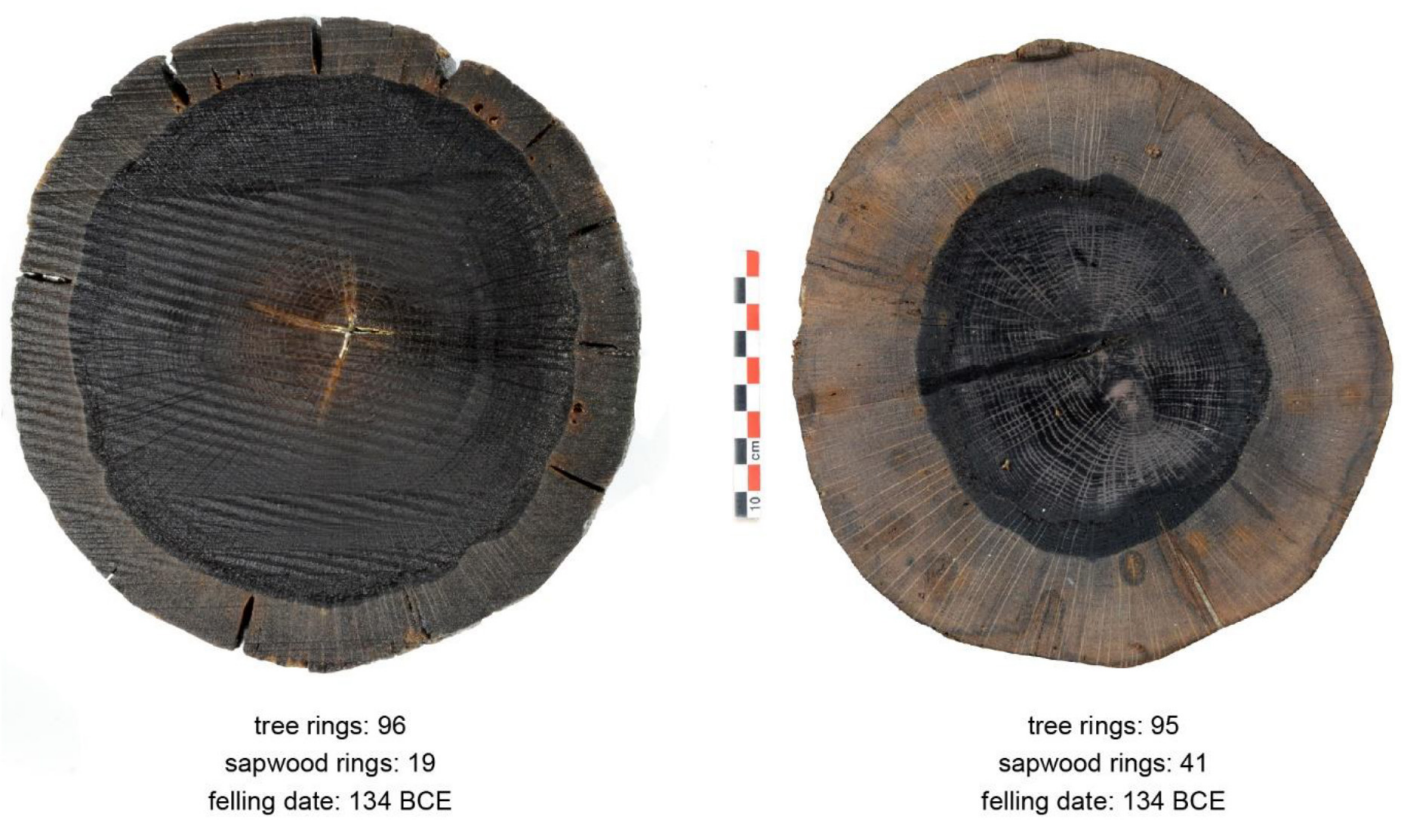

FIGURE 8 | Stem disks of two oak piles from a late Iron Age bridge (Pont-sur-Seine, France) with heart wood, sapwood and waney edge (Leroux et al., 2018).

heartwood ring, based on the empirically obtained minimum number of sapwood rings.

Regarding the number of missing sapwood rings, different statistically based estimates exist for various regions (Eißing, 2005). For example, British oaks show 10-55 sapwood rings (Hillam and Tyers, 1995), in Western Germany oaks develop 933 sapwood rings (Hollstein, 1980) and in Northern Germany 10-30 (Wrobel et al., 1993). The number of sapwood rings for Poland ranges between 9 and 23 (Wazny and Eckstein, 1991), for Southern Pannonia (SI, HR, RS) 5-32 (Jevšenak et al., 2019), for Moravia (CZ) 5-21 (Rybníček et al., 2006), and for the Baltic and Southern Finland 6-19 (Sohar et al., 2012). All of these values are estimates, based on statistical averages. Hence, the exact number of sapwood rings of an individual tree remains unknown and might differ considerably (Figure 8). Apart from the geographical region where a tree grew, its age and growing conditions can also affect the total amount of developed sapwood rings. For example, old and slow growing oak trees generally have more sapwood rings compared to fast growing or younger oak trees (Haneca et al., 2009).

\section{Contributions to Past Climate Estimation, Wood Utilization, Land Use, Settlement and Building History}

Dendrochronological dating of historical and archaeological wood has developed into a standard method in modern archaeology and other disciplines. Nevertheless, tree rings also present a valuable proxy archive for past climate and for the estimation of past wood utilization, land use changes, settlement, and building history. In recent decades, cooperation between dendroarchaeologists and paleoclimatologists have produced various climate reconstructions (e.g., Büntgen et al., 2011c; Cook et al., 2015; Tegel et al., 2020).

Trends in the growth pattern of trees can be caused by various factors and are not attributable to a single reason. To detect or enhance certain climate signals and exclude noise several statistical methods have been introduced (Fritts, 1976; Cook and Kairiukstis, 2013). They all aim for the preservation of short-term (i.e., high frequency) and long-term (low frequency) climate information. This is essential, as low to mid-frequency trends in the tree-ring chronologies allow for the investigation of decadal to multi-centennial climate variability (e.g., Medieval Climate Anomaly, Little Ice Age), whereas high-frequency signals enhance year-to-year variability and are used for extreme year analyses (Büntgen et al., 2011b). However, it remains uncertain to which extend the climate signal is superimposed by age, siteecological and anthropogenic factors. Since stand conditions of archaeological wood remain unknown, a high annual replication with trees from different sites eliminates non-climate-induced noise from dendroarchaeological tree-ring series (Tegel et al., 2010; Büntgen et al., 2012; Skiadaresis et al., 2021). Moreover, to improve the climate signal of tree-ring chronologies from archaeological wood, several approaches can be applied. First, high spatio-temporal replication and equal age distribution (Esper et al., 2009) of both archaeological and modern reference material can be achieved by applying a "random sampling" approach (Tegel et al., 2010). Secondly, each tree-ring series can be examined for cyclic growth patterns in the high to mid frequency domain that might be associated with insect calamities, e.g., cockchafer outbreaks (Kolár et al., 2013), or past forest management, e.g., coppice-with-standards (Muigg et al., 2020).

To statistically preserve and detect climatic information at different frequencies in tree-ring chronologies, an array of 
standardization methods is available that can remove nonclimate-induced noise such as biological age trends from each individual tree-ring series. Such standardization methods include different statistical models, e.g., smoothing splines, negative exponential curves or regional curve standardization (RCS) (Briffa et al., 1996).

The resulting detrended (i.e., age-trend free) tree-ring chronologies can be correlated with instrumental climate data (in most cases starting from the 20th century), demonstrating the direct relationship between climate conditions and tree growth in a region. Several methods for tree-ring based climate reconstructions have been applied within the last decades including reverse modeling, scaling and regression models (Esper et al., 2005; Büntgen et al., 2021a). Every climate reconstruction is based on the assumption that the climate-growth relationship is stable over time (Fritts, 1976).

Dendroarchaeological material with its species composition, tree age and size as well as abrupt growth changes, vessel size and formation also provides valuable insights into processes of human-woodland-interaction. For example, models of fire clearance, slash-and-burn farming, woodland degradation and forest management concepts, e.g., coppice and coppice-withstandards, have been established in spatio-temporal dimensions (Tinner et al., 2005; Bernard et al., 2006; Conedera et al., 2009; Billamboz, 2014b; Bleicher, 2014; Muigg et al., 2020). The technical evolution of tools and woodworking practices can be studied on artifacts and species selection for their development over time (e.g., Épaud, 2007; Hoffsummer, 2009; Tegel et al., 2016a). Detailed investigations of individual wooden structures allow to develop chaînes opératoires for their construction (e.g., Tegel et al., 2012).

Chronological classification and the identification of felling date clusters are crucial prerequisites for regional to supraregional studies of settlement dynamics, building activities and demographic development that can be associated with general economic developments and crises (e.g., Thun and Svarva, 2017; Ljungqvist et al., 2018; Seifert, 2018). The combination of quantitative dendroarchaeological research and Geographic Information Systems (GIS) enables spatio-temporal syntheses from local settlement dynamics to large-scale demographic developments (Nicolussi et al., 2013; van Lanen et al., 2016).

\section{SOURCES AND CURRENT STATE OF DENDROARCHAEOLOGY IN EUROPE}

\section{Chronologies}

Annually resolved and absolutely dated millennia-long treering width chronologies from living and relict wood have been developed in Europe for the Austrian Alps (9111 years; Nicolussi et al., 2009), northern Germany (8000 years; Leuschner et al., 2002), Ireland (6939 years; Baillie, 2009), northern Sweden (7400 years; Grudd et al., 2002), and Finish Lapland (7519 years; Eronen et al., 2002). The initial "Holocene Oak Chronology" by Becker (1993), has been revised and extended by the "Preboreal Pine Chronology” (Spurk et al., 1998; Friedrich et al., 1999, 2004). This composite dataset covers 12.460 years and reaches back to the Late Glacial Period with a continuous coverage, which is unique globally.

Despite the continuous temporal coverage of European chronologies, it has to be noted that there are significant differences regarding regionality, tree species and sample replication. For most regions, at least millennium-long chronologies are available for economically relevant species, but a large number of chronologies have not been comprehensively published so far. In northern and central Europe long chronologies are available for oak (Quercus spp.), silver fir (Abies alba), beech (Fagus sylvatica), spruce (Picea abies), pine (Pinus sylvestris), larch (Larix decidua), and stone pine (Pinus cembra) (e.g., Hollstein, 1980; Jansma, 1995; Neyses-Eiden, 1998; Grabner et al., 2001; Čufar et al., 2008b; Nicolussi et al., 2009; Tegel et al., 2010; Büntgen et al., 2011c, 2013, 2014; Kolář et al., 2012; Edvardsson et al., 2016a; Prokop et al., 2016; Sochová et al., 2021).

For southern Europe, multi-centennial long chronologies exist for oak (Quercus spp.), beech (Fagus sylvatica), fir (Abies spp.), juniper (Juniperus spp.), larch (Larix decidua), black pine (Pinus nigra), bosnian pine (Pinus heldreichii), and mountain pine (Pinus uncinata) (e.g., Panayotov et al., 2010; Seim et al., 2012; Szymczak et al., 2014; Tegel et al., 2014; Shindo et al., 2017; Nechita et al., 2018; Sangüesa-Barreda et al., 2018; Belingard et al., 2019; Esper et al., 2021; Roibu et al., 2021).

Many of these chronologies have been developed using living trees from old-growth forests or in combination with samples from historical timbers (Figure 2). Preserved buildings from modern and medieval periods can provide data for the last millennium. Preserved dry wood from older timber structures is extremely rare. To go further back in time, waterlogged wooden finds from archaeological excavations and subfossil trees from gravel pits and paleo-channels are of fundamental importance to extend tree-ring width chronologies. Several periods with low sample replication exist during the Holocene. Some can be linked to regional research gaps, while others are related to supra-regional phenomena, caused by changes in demography, changes in settlement systems during cultural transition periods (e.g., 5th century BCE, i.e., the onset of the Late Iron Age, and 5 th century CE, i.e., the transition from Late Antiquity to Early Middle Ages). Such phases can often be linked to crises, whereas times of socio-economic prosperity are associated with increasing amounts of wooden finds (Ljungqvist et al., 2018). In phases of low replication, subfossil trees from natural deposits provide important additional specimens. In some regions, subfossil material even provide the most important source of tree rings (Brown et al., 1986; Eronen et al., 2002; Baillie, 2009).

\section{Subfossil Wood}

Trees from past forests can be preserved in natural deposits and can be found in gravel pits, peats and bogs as well as in glacier forefields. The deposition occurs as a result of natural processes, most importantly, erosion. Such trunks allow the establishment of long tree-ring chronologies and provide important information for the history of fluvial and glacial dynamics, the evolution of treelines, peats and riparian forests as well as possible anthropogenic impacts (e.g., Becker, 1982; 
Krąpiec, 2001; Leuschner et al., 2002; Leuschner and SassKlaassen, 2003; Baillie, 2009; Edvardsson et al., 2016b). Due to the generally better preservation of subfossil trees compared to archaeological wood, they have been used for developing the radiocarbon calibration curve and are frequently used for its enhancement (Reimer et al., 2020).

Combined dendrochronological and radiocarbon evidence provide on the one hand, high resolution proxy archives for the investigation of climate variability during the Late Glacial Period and on the other hand, high-precision dating of environmental events such as earthquakes and volcanic eruptions (e.g., Nicolussi et al., 2015; Büntgen et al., 2017), particularly during periods of high climate variability but low data availability, for instance the Younger Dryas cold spell ( $\sim 1700$ and $12900 \mathrm{cal} \mathrm{BP}$ ) (Reinig et al., 2018, 2021).

Early to late Holocene glacial and tree line dynamics in high alpine areas have been investigated on regional to global scales (Nicolussi and Patzelt, 2000; Holzhauser et al., 2005; Nicolussi et al., 2005; Le Roy et al., 2015; Solomina et al., 2016).

Subfossil tree trunks preserved in alluvial infills of European rivers are of great interest to document the formation, evolution and destruction of riparian forest vegetation (Pukiene, 2003; Carozza et al., 2014; Vitas, 2017). Significant temporal accumulations of post-glacial trees deposited in river sediments indicate repeated phases of substantial floods and changes of river courses and provide insights into anthropogenic influences and destructions (Becker, 1982).

Subfossil trees from peatlands are important proxies for Holocene palaeohydrology and palaeoclimate, essential to our understanding of long-term changes in hydroclimate and the terrestrial carbon cycle (Edvardsson et al., 2016b). Even though the anthropogenic impact on subfossil trees is limited in most cases, they are substantial data sources that need to be considered for dendroarchaeological studies.

\section{Archaeological Wood}

Wooden remains from past human societies are unearthed during archaeological excavations. The oldest man-made artifacts discovered in Europe are ca. 300.000 years old hunting spears from Schöningen, Germany (Thieme, 1997; Conard et al., 2020). Substantial amounts of wooden finds, however, only appear in periods of sedentary cultures, starting from the mid-6th millennium BCE, when first farming societies settled in the fertile loess regions of Europe and systematically used large amounts of timber. Their settlements consisted of longhouses, sometimes over $40 \mathrm{~m}$ in length, for year-round habitation that required large timber sizes and technical innovations in carpentry (Tegel et al., 2012). First intensive anthropogenic influence on the natural environment happened during this time when forests were cleared to create agricultural areas. Within the last decades, several water wells from settlements of the 6th millennium BCE have been excavated in Europe. Technological studies revealed the impressive woodworking skills of Europe's first farmers. Hundreds of timbers from these water wells enabled the development of different tree-ring chronologies and are the oldest dendrochronologically dated archaeological features in Europe so far (Tegel et al., 2012; Rybníček et al., 2018, 2020).
Extraordinary preservation conditions in pile dwellings lead to the excavation of vast amounts of archaeological wood. Early examples from the 6th millennium BCE are restricted to southern Europe (e.g., López-Bultó and Piqué Huerta, 2018; Naumov, 2020; Fermé et al., 2021). In central Europe, pile dwellings appeared in the circumalpine lakes during the 5th millennium BCE and are listed as a UNESCO world heritage "Prehistoric Pile Dwellings around the Alps" since 2011, protecting a total of 111 archaeological sites in six countries. Here, absolutely dendrochronologically dated structures exist from around $4200 \mathrm{BCE}$ onward providing large amounts of waterlogged woods for dendroarchaeological studies (Billamboz and Schlichtherle, 1982; Lambert and Lavier, 1997; Billamboz and Unz, 2006; Cichocki and Dworsky, 2006; Billamboz, 2014b; Martinelli, 2014; Čufar et al., 2015; Bleicher and Harb, 2017). The combination of archaeological, archaeobotanical and dendroarchaeological data provide detailed insights into pre-historic socio-economies including their social networks, husbandry and forest management (e.g., Billamboz, 2014b; Menotti, 2015; Bleicher and Harb, 2017; Hafner et al., 2020). Pre-historic pile dwellings occurred in several waves, most likely in periods of favorable climate conditions, from the Late Neolithic until the Iron Age period at around 500 BCE (Billamboz, 2003). The documentation and dendrochronological dating of piles enables detailed investigations of settlement structures and development with high temporal precision (Bleicher and Harb, 2018). Many wetland sites are characterized by multiphase occupations with thousands of piles. Therefore, ground plans of single structures are often only recognizable after dendrochronological dating, the identification of wood species and typological studies of cross-sections (e.g., Benguerel et al., 2020). Moreover, wetland sites yield various kinds of wooden objects for every-day purposes, e.g., vessels, tools, weapons, and provide detailed insights into the material culture and technology (e.g., Müller-Beck and Boessneck, 1965; Capitani et al., 2002; Fermé et al., 2021). Outside of wetland areas, such finds are only preserved in single structures with waterlogged conditions like water wells (Croutsch et al., 2019, 2020). In recent years, largescale excavations of preventive archaeology have also discovered extensive settlement areas with waterlogged conditions in large river valleys with high groundwater levels (Donnart et al., 2019). In particular, for the Roman period the number and quality of archaeological sites increased significantly. Political and administrative efficiency led to high building activities and consequently to large amounts of archaeological wood for the 1st to 3rd century CE for many central European laboratories (Hollstein, 1980; Nicolussi, 1998a,b; Herzig and Berg-Hobohm, 2010; Benguerel et al., 2012; Herzig et al., 2013; Bernard et al., 2014; Čufar et al., 2014; Jansma et al., 2014; Tegel et al., 2016b; Jansma, 2020). The highly developed trade networks and the rising urban development triggered new dimensions of forest resource exploitation (Bernabei et al., 2019). Socio-economic decline at the end of the Roman Empire is reflected by a decrease in building activity and therefore, a limited number of

\footnotetext{
${ }^{5}$ https://whc.unesco.org/en/list/1363
} 
dendroarchaeological evidence in the late 4th and 5th centuries CE (Rzepecki et al., 2019).

In the majority of archaeological sites in Europe, no organic tissue is preserved. Here, dendroarchaeological studies are limited to chemically modified wood, e.g., charcoal or mineralized wood. These highly fragmented finds rarely show traces of the original object surface and hardly provide a sufficient number of tree rings. In most cases, they are not suitable for technological or dendrochronological analyses. However, taxonomical identification is still possible and often the minimum diameter of the used trunk can be estimated. With large charcoal datasets it is possible to answer research questions of local vegetation cover, anthropogenic land use and forest exploitation as well as dendrochronological dating (Cichocki, 2007; Nelle et al., 2010; Deforce, 2017; Blondel et al., 2018; Dufraisse et al., 2018; Moser et al., 2018; Oberhänsli et al., 2019). Mineralized wood provides distinct information regarding wood utilization and selection due to mechanical properties for specific purposes, e.g., weapon production (Tegel et al., 2016a; Haneca and Deforce, 2020).

\section{Wood From Historical Buildings}

Large amounts of historical timber, e.g., roof trusses, ceilings joists, buttresses and basement pillars, have survived under dry conditions in buildings that are in many cases still intact, enabling insights into the building history of the last millennium (e.g., Hollstein, 1980; Kuniholm and Striker, 1987; Crone and Fawcett, 1998; Büntgen et al., 2006b; Seiller et al., 2014; Bernabei et al., 2016). In particular, sacral buildings (e.g., churches), but also public and private secular architecture from medieval to modern periods are valuable data sources for dendroarchaeological studies (e.g., Hoffsummer, 2009; Seim et al., 2015; DomínguezDelmás et al., 2017; Haneca and van Daalen, 2017; Christopoulou et al., 2020b).

The dating of historical constructions is primarily initiated by departments of heritage conservation or heritage inventorization for the protection of architectural monuments or for their documentation in the context of renovation, restoration, re-use or demolition (Gomolka, 1992; Marshall et al., 2004; Harzenetter et al., 2016; Withalm, 2018). It is important for research on building history as well as for studies on urban and rural development (Schmidt et al., 2001; Eißing, 2015; Werlé, 2017; Vitas, 2020).

The position of timbers within their larger constructive context allows to investigate the evolution of new types of constructions and innovative technical solutions. Vernacular architecture shows distinct construction details (e.g., floor plans, room division), often typical for certain periods and regions and therefore, reveals local technological developments and regional differences in building traditions (e.g., Schmidt et al., 1990; Épaud, 2007; Houbrechts, 2007; Susperregi et al., 2017).

The tree species used for historical timbers vary among different regions and within each construction according to their functional purpose. For structural elements with soil (i.e., moist) contact, oak (Quercus spp.) was used almost exclusively. Other species regularly used for timber framework and roof constructions are silver fir (Abies alba), spruce (Picea abies), pine (Pinus sylvestris) and larch (Larix decidua). Sophisticated knowledge of mechanical properties and other characteristics of various tree species by historical craftsmen can be expected (Blau, 1917). The regional preference of a species is strongly affected by its natural distribution (Kolár et al., 2021; Shindo and Giraud, 2021; Sochová et al., 2021; Solomina and Matskovsky, 2021). For example, in the lowlands of western Europe oak was regularly used for all components of vernacular buildings due to the rare occurrence of conifers (Haneca et al., 2009; San-Miguel-Ayanz et al., 2016). Northern Europe's vernacular architecture was dominated by pine, whereas fir and spruce are more frequently found in central European constructions (Becker and Giertz-Siebenlist, 1970; Eißing and Dittmar, 2011; Seim et al., 2015; Thun and Svarva, 2017; Kolár et al., 2021). Larch is restricted to high elevation areas in the Alps and parts of the Tatra Mountains, where it was also preferentially used (Büntgen et al., 2006a, 2013). Larch (from the Alps) was massively used also in the areas dominated by the Venetian Republic Serenissima (e.g., Levanič et al., 2001). The most frequently used species in the Mediterranean region are oak (Quercus spp.), chestnut (Castanea sativa), pine (Pinus spp.), fir (Abies spp.), juniper (Juniperus spp.), and cedar (Cedrus spp.) (Bernabei et al., 2016; Christopoulou et al., 2020a). In the sparsely wooded regions of the Mediterranean, timber import played a particularly significant role (Domínguez-Delmás et al., 2018; Bernabei et al., 2020; Christopoulou et al., 2020a).

There are chronological and regional differences regarding the data basis of historical timber constructions in Europe. Many modern towns and rural villages were just established during the consolidation of high medieval political structures in the 12th-13th century and those urban settlements that had existed before ca. 1200 CE have been affected largely by structural changes during the 13th century and later extensive reorganizations (e.g., Bartlett, 1994; Westphal, 2002; Mitchell, 2013). Therefore, the early centuries of the last millennium are generally underrepresented. The vast majority of all studied timbers are from towns, typically small ones in rural settings that in many cases have lost their importance in modern times. Because of that, old buildings were more likely to survive the destruction caused by later wars and urban renewal in the 19th and 20th centuries than buildings in major cities. Rural farm buildings pre-dating the 17th century are rarely preserved and are therefore only represented to a limited extent. For large parts of central Europe, the Thirty Years' War (1618-1648) might have greatly decimated older buildings in rural areas (Ljungqvist et al., 2018).

\section{Wood From Objects of Art History, Instruments, and Furniture}

Dendroarchaeological analyses can also be applied on wooden art objects like panel paintings, sculptures, furnishing items and musical instruments. The most important research questions for these high-quality objects are precise dating and provenance of the wood and is mainly initiated by art historians in museums or art dealers. As the actual origin of the wood for the highly specialized art sector is unclear in many cases, these sources are 
not included in paleoclimatological studies. However, wooden art objects provide information on historical species selection and woodworking techniques.

The first dendrochronological analyses of panel paintings in Europe were conducted on works by German medieval painters in the 1960s and ' 1970 s by the German biologist Josef Bauch (1968). In the mid-1970s, J. M. Fletcher followed and dated panel paintings done by 15th- to 17th-century English and Flemish artists (Fletcher, 1975). From this point on, dendrochronology has been commonly applied to art objects (Bauch and Eckstein, 1970, 1981; Bauch, 1978; Bauch et al., 1978; Klein, 1986, 1998; Klein and Wazny, 1991; Hillam and Tyers, 1995) and musical instruments (Klein, 1985, 1996; Topham and McCormick, 1998; Beuting and Klein, 2003; Topham, 2003; Beuting, 2009; Bernabei et al., 2010, 2017; Čufar et al., 2017). For musical string instruments, the material is carefully selected, such as spruce trees with hazel growth, an uniformly finely striped texture, which were found to produce the best sounds (Buksnowitz et al., 2007; Brandstätter, 2016; Bucur, 2016).

Non-invasive methods are applied and the tree-ring widths of the planks are measured either directly on the planks of the panel or instrument or on macro-photos (of ca. $5 \mathrm{~cm}$ segments) which are taken from the cross section of the panels (Myhr et al., 2007). Even more modern technologies using an industrial CT scanner or X-ray technology allow the analysis of tree rings noninvasively (van den Bulcke et al., 2014; Stelzner and Million, 2015; Daly and Streeton, 2017; Domínguez-Delmás et al., 2021a). Dendrochronological analyses on furniture are less common but similarly important as they highlight woodworking and stylistic changes in the society (Pickvance, 2012, 2015; Klein et al., 2014; Allen, 2015; Domínguez-Delmás et al., 2021b).

\section{APPLICATION AND MULTIDISCIPLINARY FIELDS IN DENDROARCHAEOLOGY}

\section{Evolution of Woodworking Technology}

Since the Paleolithic, wood has been an important raw material for various purposes, e.g. hunting weapons (Thieme, 1997; Lozovski et al., 2016; Conard et al., 2020). Mobile huntergatherer communities of the Upper Paleolithic (50-12 ka BP) and Mesolithic (ca. 15-5 ka BP) periods used wood for the production of tools, weapons and short-lived housing. First important innovations in woodworking technology are recognizable during the Neolithic period (ca. 6000-2200 BCE) when the establishment of a sedentary lifestyle required the processing of larger timber for permanent buildings, which are suitable for year-round habitation. Water wells from this period provide evidence for the utilization of large oak trees, frequently split for the use in block constructions, and sophisticated carpentry techniques for surface treatment and corner joints (Tegel et al., 2012; Rybníček et al., 2018, 2020). Analyses of toolmarks on the preserved timber provide evidence for the use of different tools for specific working steps (Elburg et al., 2015). Different types of construction produced by Neolithic carpenters illustrate the impressive woodworking skills of Europe's first farmers (Rybníček et al., 2020). In the further course of the Neolithic period, large-scale constructions consisting of hundreds of mature oaks suggest the collaboration of larger communities and provide evidence for socio-economic developments (Donnart et al., 2019). Oak remained the preferred species for construction timber throughout the pre-historic and proto-historic periods in Europe.

New impulses for carpentry techniques were provided with the occurrence of new materials for the production of tools. Bronze first occurred in large parts of Europe during the late 3rd millennium BCE and the technology of iron production spread in the early 1st millennium BCE. The use of metal tools enabled the development of new woodworking techniques and novel types of constructions. Important innovations are the development of new tools, e.g., wood borers and saws that together with other inventions further accelerated the civilization of Europe. Improvements in iron technology in late Iron Age and Roman Europe allowed the development of large saws suitable for longitudinal cutting of trunks, which facilitated the production of planks and boards (Figure 9). This, together with the invention of the carpenter's plane in Roman times, revolutionized furniture making (Goodman, 1963; Schadwinkel et al., 1986). The use of hydro-power as a mechanical labor force for grain mills was first applied in European Antiquity and further developed in different regions of early medieval Europe (Wikander, 1984; Spain, 2008; Rynne, 2015; Muigg et al., 2018). The mechanics of watermills are entirely made of wood and require extensive mechanical knowledge and high-precision carpentry. These first complex mechanical machines were also adapted for cutting wood, with first sawmills appearing in central Europe around 1200 CE (Finsterbusch and Thiele, 1987; Berthold, 2009). The milling technology spread throughout medieval Europe in the 12th and 13th century and was a main driver for changing economic structures (Jeute, 2015). During the late medieval and early modern periods, the development of craft guilds and the diversification of woodworking professions lead to a great variety of specialized tools (Goodman, 1963; Schadwinkel et al., 1986; Finsterbusch and Thiele, 1987; Greber, 1987).

\section{Trade of Woods and Goods}

As a consequence of the sedentary lifestyle, developed in large parts of Europe during the Neolithic period, forest areas in the vicinity of settlements were intensively exploited, which successively led to a shortage of timber. Therefore, wood had to be harvested from further away and transported to the settlements. Prehistoric settlement patterns are frequently found on lakeshores and riversides, which enabled effortless transport on water by towing or rafting of construction material. Timber from the same forest stand that was found in different dwellings on the northern and southern shore of Lake Constance provides indirect evidence for timber transport (Benguerel et al., 2020).

First proof for local timber transport on water is provided by a Neolithic palisade from La Villeneuve-au-Châtelot (Aube), dated to $3232 \mathrm{BCE}$, where characteristic recesses in various timbers suggest the assemblage of rafts (Donnart et al., 2019; Figure 10). In contrast to transportation on water, overland transport was a much more tedious process. Since the Neolithic, large amounts of wood were used for road building to enable 

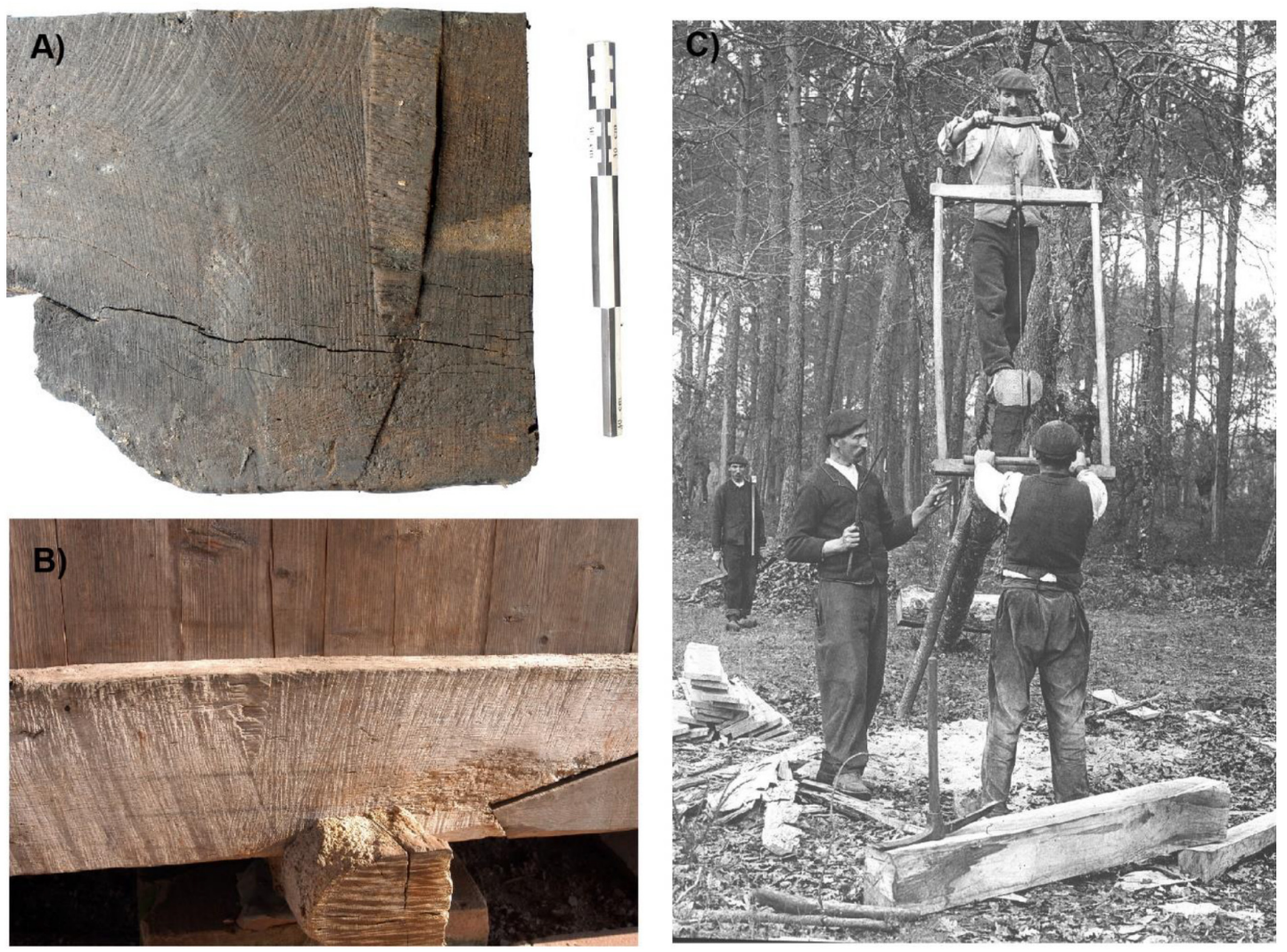

FIGURE 9 | Longitudinal sawing of planks and boards. (A) Oak board with a characteristic "V" saw mark from the Roman harbor in Reims, France (1st century CE) and (B) sawing marks with a characteristic "V" mark on a beam from a historical building in Le Val-d'Ajol, France (18th century CE). (C) Historical postcard from La Baconničre, France, depicting the sawing process.

land transportation in marshy areas (Hayen, 1990; Fansa, 1992; Endlich and Lässig, 2007). First evidence for chariot wheels from Europe date to the late 4th and early 3rd millennium BCE (Höneisen et al., 1989; Velušček and Čufar, 2009; Schlichtherle, 2010). Around 2000 BCE the domesticated horse spread throughout Europe, providing a new type of working animals suitable for faster transportation (Anthony, 1995), which led to the development of new chariot and wheel types during the early Bronze Age (Heussner, 1985; Tegel and Croutsch, 2016). The bronze-age invention of steerable front axles had an impact on the size of wooden roads, which were built narrower than in Neolithic times (Fansa, 1992). During the Bronze Age, chariots were not exclusively used for transportation but also became objects of prestige. The prestigious image of wheel chariots continues through the Iron Age and is visible in elite graves furnished with chariots (Biel, 1995; Laurent et al., 2002).

Besides chariots, ships were the most important means of transport for timber. These vehicles themselves were entirely or predominantly made from wood and played a pivotal role for the transportation of various other goods.

Simple monoxyle log boats are known in Europe as early as the Mesolithic period and were in use until post-medieval times for fishing and short distance transport in certain regions
(Arnold et al., 1995; Lanting, 1997; Kröger, 2014). The oldest archaeological evidence of a raft of combined logs was found in 1922 at the "Wilden Ried" in Upper-Swabia, Germany, dating to the Bronze Age (Ellmers, 1972). However, it can be assumed that such rafts were already used in earlier periods (cf. Donnart et al., 2019). Larger vessels both for inland and maritime navigation required more complex constructions. The oldest examples for such ships found in Europe date to the Iron Age, e.g., from Hjortspring, Denmark (CrumlinPedersen and Trakadas, 2003). Archaeological evidence of ships with laced planking for the 6th century BCE in Massalia (Marseille), France, and for the 3rd century BCE in Ljubljana, Slovenia, illustrate the influence of the Mediterranean maritime ship building traditions on European inland navigation vessels (Pomey, 1996; Teigelake, 1998). Different types of ships have developed since the Roman era (Arnold, 1992; Bockius, 2002, 2006) and further technological innovations can be recognized for medieval and post-medieval times (Bridge and Dobbs, 1996; Hakelberg, 1996; Crumlin-Pedersen et al., 1997; Hoffmann and Schnall, 2005; Lemée, 2006; Jansma et al., 2014; Englert and Crumlin-Pedersen, 2015). For all these mobile wooden vessels, their excavation site might differ considerably from their site of construction (Bonde, 1998; Domínguez-Delmás et al., 2019), making them important objects of research 
A
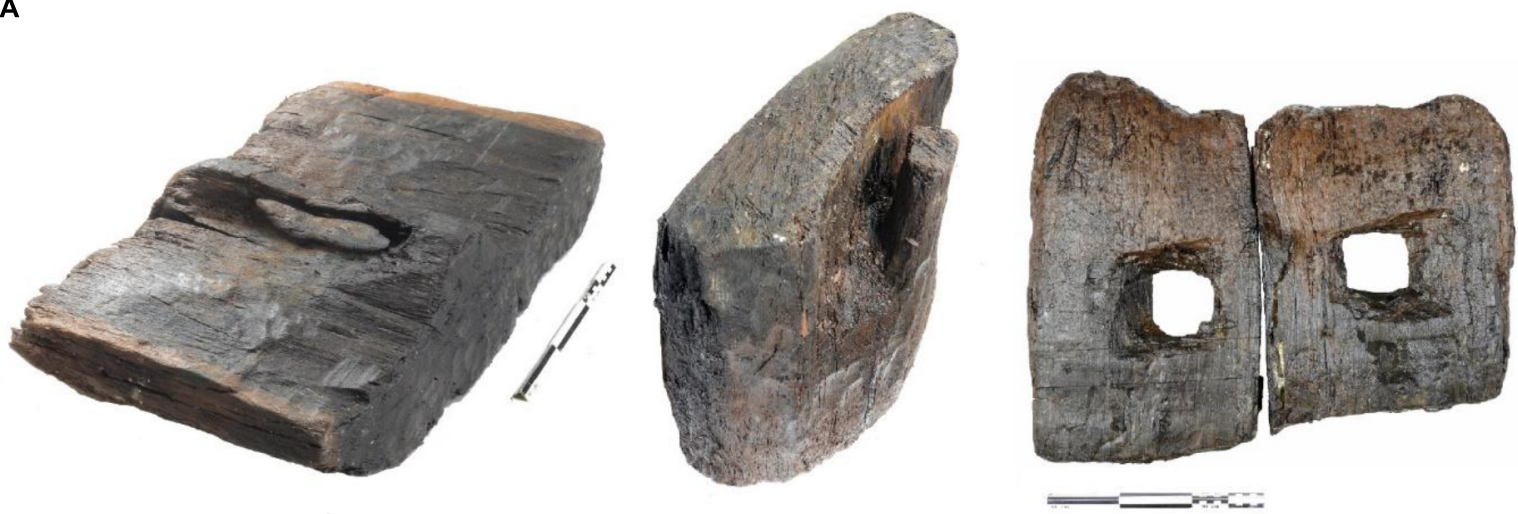

B
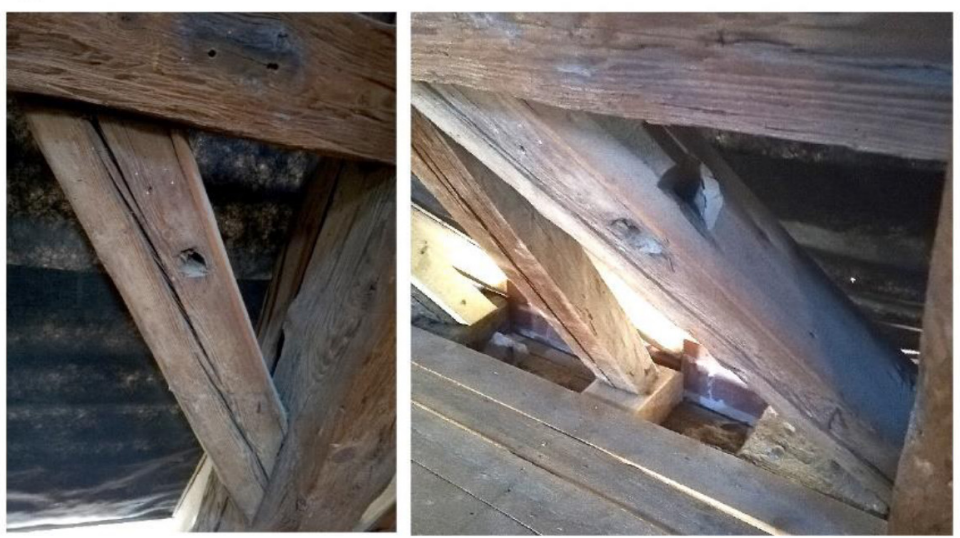

C

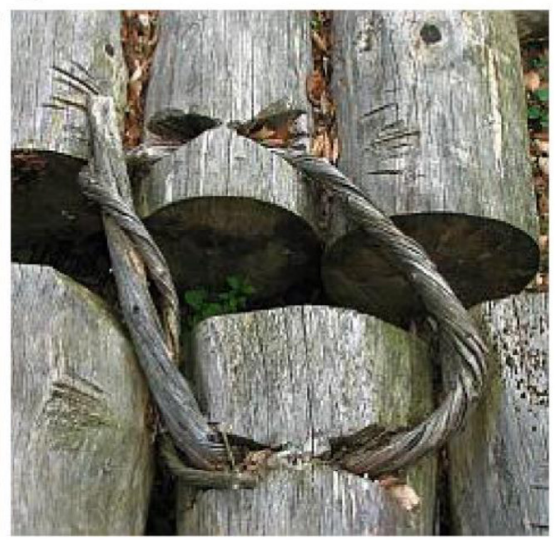

FIGURE 10 | (A) Oak posts from a Neolithic palisade (3231 BCE) with recesses on the basis used for timber floating or over land transport (Donnart et al., 2019). (B) Recesses on construction wood frequently found in roof trusses (Colmar, Alsace, France, 18th century CE) typical for timber rafting. (C) Detail view on the raft assemblage of a modern reconstructed raft.

for dendroprovenancing (Daly, 2007; Daly and Nymoen, 2008; Bridge, 2012; Domínguez-Delmás et al., 2013).

The same applies for wooden barrels, used as containers for various trading goods and frequently re-used in well linings or latrines at their final destinations in Roman and postRoman settlements (Ulbert, 1959; van Es, 1972; Greig, 1981; Clerici, 1983; Marličre, 2002; Falk, 2003; Hagendorn and Bouchet, 2003; Bauer, 2009; Robben, 2009; Čufar et al., 2019; Mille and Rollet, 2020). Barrels are elaborately crafted objects that reveal detailed information about the precise wood technology and manufacturing as well as trade systems (Marličre, 2002; Tamerl, 2010). Moreover, brand marks and graffiti found on barrels provide information for epigraphic and other studies (Frei-Stolba, 2017).

Wood itself was an important trading good. First indication for long-distance timber transport was found during the Antiquity for silver fir (Abies alba) for the construction of Roman harbors and bridges in regions outside the natural habitat of the species, e.g., in Mainz and Cologne (Bauer, 2001; Tegtmeier, 2016). Further evidence for Roman long-distance timber transport was found in Voorburg-Arentsburg, Netherlands (Domínguez-Delmás et al., 2014). New dendroarchaeological research shows a combined river and sea transportation of oak planks from regions north of the Alps for a construction in the city of Rome, further illustrating the necessary advanced logistic infrastructure (Bernabei et al., 2019). In post-roman Europe (after the first Millennium CE), growing population and fast urban development accelerated the decline of regional forests (Kaplan et al., 2009; Deforce, 2017) and led to the development of intense timber trade on the continental waterways through sea trade and river systems (Ellmers, 1985; Eißing and Dittmar, 2011). First historical evidence for medieval timber rafting on various large and smaller rivers date from the 12th and 13th centuries (Neweklowsky, 1952; Irsigler, 1992; Henne, 2005; Eißing and Dittmar, 2011), demonstrating the rising importance of timber transport on rivers (Delfs, 1985; Heussner, 2015). The development of extensive rafting infrastructures in mountain regions led to progressive exploitation of new forest areas for both, fuelwood and timber (Neweklowsky, 1959). Protoindustrial glass and salt production emerged to major consumers for fuelwood (Lamschus, 1993; Goldammer, 1998; Grabner et al., 2018). The prevalence of coniferous species in the timber material from historical buildings in large parts of central Europe, noticeable from the 14th century onward, provides 
strong evidence for extensive timber transport on a continental scale. Occasionally, traces of rafting can be found on timber elements in historical buildings (e.g., Eißing and Dittmar, 2011; Zunde, 2011; Shindo and Claude, 2019; Figure 10B). Regional differences of technical solutions for combining logs, varying for different river systems, hold information on the origin of timber (Eißing et al., 2012).

Selected, high quality timber, especially from oak, for art objects was in high demand also after local old forests were depleted in some regions in western and central Europe already by the 10th century (Deforce, 2017). Consequently, from the mid14th century, increasing amounts of long-lived, straight-grained oak trees were imported from Poland and the other states around the Baltic Sea (Wazny, 1992, 2002; Bonde et al., 1997; Haneca et al., 2005; Fraiture, 2009). The Baltic timber trade was actively practiced by the Kingdom of Sweden and the Polish-Lithuanian Commonwealth with England and the Low Countries in the 14th to 18 th century (Kirby, 2014). The transport was done on ships and mainly with prepared planks, boards, deals etc. (Johansen, 1983; Belasus, 2017).

\section{Forest History}

Comprehensive dendroarchaeological datasets established by European laboratories provide information on the anthropogenic impact on forest environments. The natural composition of species in European forests depends on various factors, including soil properties, environmental and climate conditions, the ecological amplitude of different tree species, the timing of species occurrence as well as the inter-species competition within a forest ecosystem (Ellenberg, 1996). However, human societies have influenced the natural forest composition in large parts of Europe throughout the Holocene. First indirect human impact on post-glacial forests might have already happened in the Mesolithic period through hunting pressure on large herbivores as well as facilitating the distribution of species through gathering, e.g., hazelnuts (Küster, 1996). Distinct human impact on forest compositions started at least with the emerge of sedentary societies during the Neolithic period that extracted construction timber and cleared forest areas for agriculture and settlements. Growing populations and successive colonization of suitable areas throughout the pre-historic and historical periods were accompanied by increasing forest exploitation. Hence, there are hardly any natural forests left in the western parts of Eurasia (Malzahn, 2011).

For millennia, people have been using forest resources for various purposes of their everyday life. To cover a constant demand of wood, e.g., for fuel and timber from the same forest areas, local communities had to develop strategies for sustainable resource availability. Large amounts of dendroarchaeological data from pile dwellings at Lake Constance suggest cyclic utilization of local forest stands as early as the late Neolithic period (Billamboz, 2014b). After a first phase of clearing primary forests, several different forms of forest treatment can be postulated from dendrotypological studies on timber size, individual tree age and growth patterns during the Neolithic occupation (Billamboz and Köninger, 2008; Billamboz, 2014a). Coppice-like forest structures are documented for the 36th century $\mathrm{BCE}$ in phase IB at the Neolithic pile dwellings at Hornstaad-Hörnle (D), yet without evidence for systematic management (Billamboz and Unz, 2006). Alternating phases of over-exploitation of local forests through harvesting and grazing, subsequent degradation, change of utilized forest area, natural reforestation and clearing display the complex interaction of natural and anthropogenic factors. First evidence for successive use of the same forest stands by local communities is provided by the dendroarchaeological data from Sipplingen-Osthafen (D), where continuous building activities between 2915 and 2864 BCE confirm coppice-like forest management (Billamboz and Köninger, 2008). Similar forest management systems have been studied for Bronze Age and Iron age settlements (e.g., Reynolds, 1985; Andraschko, 1996; Billamboz and Schöbel, 1996). Other possible silvicultural systems, for example coppicewith-standards-like forest structures cannot be ruled out for pre-historic communities. However, such management practices, presupposing intensive large-scale forest clearing and the absence of alternative regional wood sources, require certain demographic conditions, which probably did not occur in most regions of Europe before the Roman period (Lo Cascio, 1994).

The first historical evidence for coppice-with-standard forest management in Europe appear at the beginning of the 13th century CE (Hausrath, 1982). As a result of population growth and urbanization, this silvicultural system was necessary to secure the constant supply of timber and fuelwood for medieval central Europe. Improved administrative structures, crucial for such long-term regulations that required planning by local authorities, led to a surplus of historical evidence, i.e., written sources, during late medieval and early modern periods (Hausrath, 1982). New dendroarchaeological studies, however, provide strong evidence for the existence of this more sophisticated silvicultural practice as early as the 6th century CE and therefore throughout a ca. 1400-year long period from early medieval to modern times (Muigg et al., 2020). Coppice and coppice-with-standards management has played an important role during medieval and early modern times until the use of fossil fuels provided alternatives to fuelwood and allowed the transformation of economic forests to modern high forests (Schmidt, 2002). Before that, countless historically recorded disputes and conflicts of interests illustrate an intensification of resource scarcity in many parts of Europe (Epperlein, 1993; Warde, 2006, 2018). Similar conflicts have to be assumed also for densely populated areas in earlier periods/pre-historic times but cannot be verified due to the lack of historical records. Nevertheless, dendroarchaeological parameters, i.e., changing annual growths, tree age classes and species might display long-term spatio-temporal changes in European forest management regimes (e.g., Haneca and Beeckman, 2005; Deforce and Haneca, 2015; Deforce et al., 2020).

\section{Environmental History (Climate, Anthropogenic Land Use, Deforestation)}

Interannual variability in growth increment is one of the fundamental features of dendroarchaeology. Inter- and intra-annual tree ring parameters such as variability in wood density, stable $\left(\delta^{13} \mathrm{C}\right.$ and $\left.\delta^{18} \mathrm{O}\right)$, and unstable $\left(\delta^{14} \mathrm{C}\right)$ 
isotopes are also highly suitable natural proxy data for environmental reconstructions, in particular climate, as they provide information with high temporal and spatial resolution. Today, they form the primary basis for palaeoclimatology of the last centuries to millennia (Stocker, 2014). In Europe, dendroclimatological studies have mainly focused on temperature reconstructions based on coniferous species of the high altitudes in the Alps (Büntgen et al., 2006b; Corona et al., 2010), the Pyrenees (Büntgen et al., 2008), the Carpathians (Popa and Kern, 2009; Kaczka et al., 2016), and the boreal forests in Scandinavia (Grudd, 2008; Helama et al., 2009; Esper et al., 2014). Annual tree growth at such treeline sites is primarily controlled by temperature during the short growing season (June-August) and thereby a distinct temperature signal in series of both tree-ring width and maximum latewood density is present (e.g., Esper et al., 2016). Aside from hydroclimatic reconstructions from extreme sites such as the eastern Mediterranean (Akkemik et al., 2008; Klippel et al., 2018) and North Africa (Esper et al., 2007), coniferous species from southern Scandinavia (Helama et al., 2005; Seftigen et al., 2013), Slovenia (Čufar et al., 2008a), Moravia (Brázdil et al., 2002; Büntgen et al., 2011a), and southern Germany (Wilson et al., 2005) provide precipitation reconstructions for central and northern Europe. For hydroclimate-sensitive broadleaf tree species at low elevations in Central Europe, however, only a few studies are available so far (Kelly et al., 2002; Cufar et al., 2008a; Büntgen et al., 2010, 2011c, 2021b; Scharnweber et al., 2019; Tegel et al., 2020).

Information relevant for forest ecology can be obtained from the distribution of species in archaeological material. Local to regional differences over time indicate changes in natural woodland societies. Long-term changes of forest ecosystems can be studied in conjunction with palynological records and yield important information on the migration history of species and establishment and consolidation of forest communities (Tinner and Lotter, 2006).

Other wood anatomical characteristics of archaeological wood provide further information to study past ecological conditions. Defoliation leads to growth reactions visible in the anatomical structure of trees, for example abnormal earlywood zones, irregularly shaped, small vessels or slightly thickened latewood tissue cells (Schweingruber, 1996). There are various possible reasons for defoliation events, for example anthropogenic (pollarding, management) or natural (floods, storms, insects) (Figure 11). Even though it is not always possible to attribute an anatomical feature to a specific event, the combination of wood anatomical observations and tree-ring patterns allow further interpretation. For example, a larger earlywood section combined with characteristic tree-ring patterns observable in archaeological wood samples has been attributed to insect calamities (Büntgen et al., 2009; Kolár et al., 2013; Figure 11A). Massive cockchafer outbreaks follow a 3-5-year cycle depending on the region. They occur during the early vegetation period and result in significant defoliation, which is accompanied by a reduced radial growth in combination with a higher amount of earlywood vessels (Kolár et al., 2013; Figure 11A). This leads to a distinct cyclic tree-ring pattern, occasionally found in subfossil trees and archaeological timber (Rohmer and Tegel, 1999; Herzig and Seim, 2011). Distinct growth reduction and vessel anomalies can also be associated with pollarding and flood events, causing partial defoliation (Figure 11B). However, a differentiation is only possible in combination with dendrochronological studies and strongly depends on an attributable tree-ring pattern. Several other wood anatomical features (e.g., frost rings, physical injuries and overgrowth, reaction wood, traumatic resin duct) can be found in archaeological and subfossil material, albeit their specific interpretation relies on the amount of data and the overall context.

\section{Dendroarchaeology and Radiocarbon Dating}

Another fundamental method for dating in archaeology is based on the partial decay of radioactive isotopes (radiocarbon, $\delta^{14} \mathrm{C}$ ) contained in organic finds. The atmospheric radiocarbon content varies because of changes in upper atmosphere production and global carbon cycling. Therefore, radiocarbon dating and dendrochronology are strongly interconnected, as tree rings provide an important source for calibrating the radiocarbon variability over time. The calibration curve, used as a worldwide standard for radiocarbon (14C) dating over the past ca. 50.000 years, is continuously improving toward a higher resolution and replication (Reimer et al., 2020). Tree rings from dendroarchaeological sources contain high-precision data throughout the Holocene. Recent studies have shown the significance of tree-ring-based calibration also for the Late Glacial Period (e.g., Reinig et al., 2020, 2021).

The interconnection of the two methods of dendrochronology and radiocarbon dating also allows the calibration of millennialong dendrochronological records. Improved inter-annual radiocarbon measurements enable to observe sudden and anomalous activity shifts, such as significantly increased atmospheric production rates of cosmogenic radionuclides on a global scale (Miyake et al., 2012; Usoskin et al., 2013; Jull et al., 2014; Büntgen et al., 2018). The detection of such events enables to independently validate tree-ring chronologies on both hemispheres and can furthermore contribute to connecting synchronous events with other long-term proxy records, for example isotopes from corals and ice cores (e.g., Liu et al., 2014; Mekhaldi et al., 2015).

Annually resolved chronologies are paramount to precisely date past volcanic eruptions not recorded in historical documents (Büntgen et al., 2017; Hakozaki et al., 2018). Starting from a distinct and well-known event, e.g., the 774/775 $\mathrm{CE}{ }^{14} \mathrm{C}$ spike (Miyake et al., 2012), the dating of an unknown event can be established by counting the number of rings to the waney edge. An other prominent example is the precise dating of Viking activity in Newfoundland in $1021 \mathrm{CE}$ by making use of the rapid ${ }^{14} \mathrm{C}$ excursion at $993 \mathrm{CE}$ (Kuitems et al., 2021). In this way, all wooden finds worldwide, which show such rapid ${ }^{14} \mathrm{C}$ excursions, can be accurately dated. This is all the more important for regions lacking dendrochronological reference chronologies.

However, it is paramount for multi-proxy synchronization that the independent dating results from tree rings and 

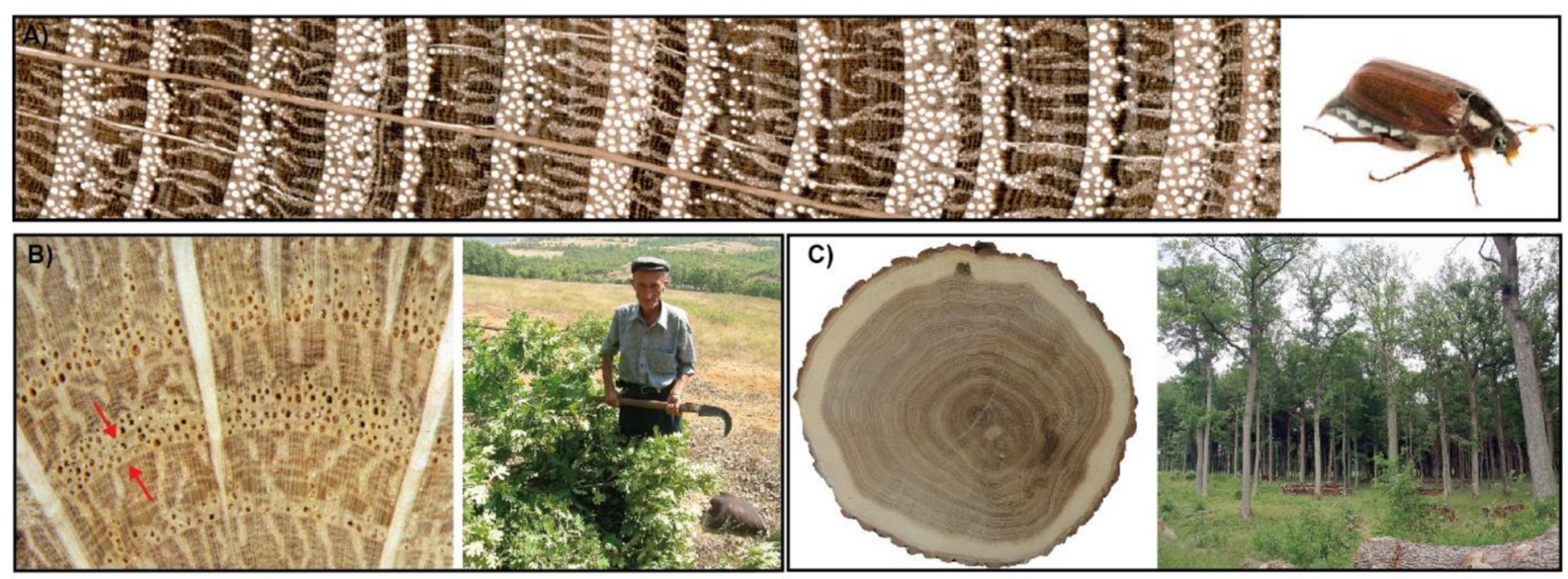

FIGURE 11 | Tree-ring anomalies. (A) Cockchafer outbreak pattern on a recent oak from Diesenhofen, Switzerland, with cyclic growth reductions every three years combined with higher early wood production. (B) Two years reduction in tree-ring width (red arrows) by pollarding of oak (Quercus cerris, Albania). (C) Stem disk from an oak standard (Welbhausen, Germany) with periodical growth release pattern induced by coppice-with-standard forest management practice.

\begin{tabular}{|c|c|c|c|c|}
\hline QUESTIONS & SOURCES & WOOD & ANALYSES & RESULTS \\
\hline $\begin{array}{c}\text { Chronology } \\
\text { Wood Technology } \\
\text { Wood Utilisation } \\
\text { Woodland Management } \\
\text { Climate }\end{array}$ & $\begin{array}{l}\text { Archaeological contexts } \\
\text { Historical buildings } \\
\text { Natural deposits } \\
\text { Forests and lumber yards } \\
\text { Museums collections }\end{array}$ & $\begin{array}{l}\text { Structural/working timbe } \\
\text { Fuelwood/charcoal } \\
\text { Subfossil wood } \\
\text { Modern trees } \\
\text { Art objects } \\
\text { Furnitures } \\
\text { Music instruments }\end{array}$ & $\begin{array}{l}\text { Tree rings } \\
\text { Wood identification } \\
\text { Wood anatomy } \\
\text { Woodworking }\end{array}$ & $\begin{array}{l}\text { Dendrochronological data } \\
\text { Enviromental reconstruction data } \\
\text { Technological records }\end{array}$ \\
\hline \multicolumn{3}{|c|}{ RESEARCH AND TEACHING } & \multicolumn{2}{|c|}{ APPLICATIONS } \\
\hline $\begin{array}{c}\text { History } \\
\text { History of Technolog } \\
\text { History of Art } \\
\text { Archaeology }\end{array}$ & $\begin{array}{c}\text { Forestry } \\
\text { Quaternary Geology } \\
\text { Geography } \\
\text { Palaeoecology }\end{array}$ & & \multicolumn{2}{|c|}{$\begin{array}{l}\text { Environmental Heritage } \\
\text { Cultural Heritage } \\
\text { Museum Display }\end{array}$} \\
\hline
\end{tabular}

radiocarbon are compared on the annual scale, as the common decadal or semi-decadal resolution of radiocarbon dates can lead to misinterpretations (Jull et al., 2021). So far, verified spikes in ${ }^{14} \mathrm{C}$ activity could be observed for 993/994 CE, 774/775 CE, 660 BCE, 813 BCE and 5480 BCE (Mekhaldi et al., 2015; Miyake et al., 2017; Park et al., 2017; Jull et al., 2018; O’hare et al., 2019). Given the great success of recent investigations in identifying and precisely addressing such events, it is to be expected that further intensified research might reveal additional atmospheric ${ }^{14} \mathrm{C}$ spike excursions.

\section{CONCLUSION}

Dendroarchaeology is a remarkably wide research field, which can offer essential contributions to a variety of disciplines and should not be restricted to delivering absolute dating (Figure 12). Wooden remains can be found from almost all epochs. Therefore, dendroarchaeologists should generally be open to interdisciplinary approaches and need to stay open-minded toward all areas of palaeosciences. A major prerequisite for dendroarchaeological studies is a comprehensive data base, well-replicated over time. The amount of high-quality tree-ring data varies greatly for different regions of Europe, especially south and south-east of the Alps. The development of millennia-long tree-ring chronologies for the main European tree species is an ongoing process and needs to be further developed constantly for more regions within the Old World (Nechita et al., 2018; Christopoulou et al., 2020a; Roibu et al., 2021). Therefore, all available sources of wood should be used: subfossil trees, archaeological finds, historical buildings, 
art objects and modern trees are essential to build and improve dendroarchaeological records.

The diversity of sources requires active cooperation between experts of dendroarchaeology as well as beyond disciplinary boundaries. So far, the most fruitful and close interdisciplinary cooperation have been implemented with archaeologists, historians, physicists, climatologists, geologists and palynologists, providing important contributions to dating, history of technology, radiocarbon calibration, palaeoclimate reconstructions, volcanic activities and vegetation history, just to name a few.

Considering the recent advances in studies of ancient plant DNA, the field of aDNA holds a great potential for combined studies on postglacial migration and climatic adoption of tree species as well as provenancing wooden objects (Wagner et al., 2018; Saleh et al., 2021). Different fields of dendro-sciences have developed various novel approaches, for example by studying density fluctuations, earlywood/latewood ratios and variances of vessel size, allowing to extract further information on the inter- to intra-annual regimes and to combine these different parameters (e.g., Wilson et al., 2017; Mann et al., 2018; Akhmetzyanov et al., 2019; Björklund et al., 2019).

\section{REFERENCES}

Akhmetzyanov, L., Buras, A., Sass-Klaassen, U., den Ouden, J., Mohren, F., Groenendijk, P., et al. (2019). Multi-variable approach pinpoints origin of oak wood with higher precision. J. Biogeogr. 46, 1163-1177.

Akkemik, Ü, D’Arrigo, R., Cherubini, P., Köse, N., and Jacoby, G. C. (2008). Treering reconstructions of precipitation and streamflow for north-western Turkey. Int. J. Climatol. 28, 173-183. doi: 10.1002/joc.1522

Allen, S. J. (2015). Wooden Coffins and Grave Furniture from 12-18 Swinegate, 14 Little Stonegate, and 18 Back Swinegate, York (YORYM 1989.28, 1990.28, 1990.1). York: York Archaeological Trust for Excavation and Research.

Andraschko, F. M. (1996). Überlegungen zum Holzbedarf ur-und frühgeschichtlicher Siedlungen. Alt-Thüringen 30, 81-100.

Anthony, D. W. (1995). Horse, wagon \& chariot: Indo-European languages and archaeology. Antiquity 69:554. doi: 10.1017/s0003598x00081941

Arnold, B. (1992). Batellerie gallo-romaine sur le lac de Neuchâtel. Archéol. Neuchâteloise 2:227.

Arnold, B., Gassmann, P., Lambert, G., and Lavier, C. (1995). Pirogues monoxyles d'Europe centrale, construction, typologie, évolution. Lausanne: Musée cantonal d'archéologie.

Atzbach, R. (2012). The concealed finds from the Mühlberg-Ensemble in Kempten (southern Germany): post-medieval archaeology on the second floor. PostMedieval Archaeol. 46, 252-280. doi: 10.1179/0079423612z.00000000012

Baillie, M. G. L. (1977). The Belfast oak chronology to AD 1001. Tree-Ring Bull. 37, $1-12$.

Baillie, M. G. L. (1982). Tree-ring dating and archaeology: Croom Helm Studies in Archaeology. Chicago: Croom Helm.

Baillie, M. G. L. (2009). The radiocarbon calibration from an Irish oak perspective. Radiocarbon 51, 361-371. doi: 10.1017/s0033822200033877

Baillie, M. G. L., and Pilcher, J. R. (1973). A simple crossdating program for tree-ring research. Tree-Ring Bull. 33, 7-14.

Baird, J. (2018). Dura-Europos. London: Bloomsbury Publishing.

Balzano, A., Novak, K., Humar, M., and Čufar, K. (2019). Application of confocal laser scanning microscopy in dendrochronology. Les/Wood 68, 5-17. doi: 10. 26614/les-wood.2019.v68n02a01

Bannister, B., and Robinson, W. J. (1975). Tree-ring dating in archaeology. World Archaeol. 7, 210-225. doi: 10.4324/9781315748689-23
However, these innovative approaches are only partially transferable to archaeological wood. Large differences in quality and type of wood preservation, combined with the inherent lack of stand and tree level information, pose limits to a generalized inclusion in dendroarchaeology. Therefore, total tree-ring width provides the most accurate, most widely used and consequently the most valuable parameter for dendroarchaeological treering studies.

\section{AUTHOR CONTRIBUTIONS}

WT, BM, and AS searched and reviewed the literature and wrote the manuscript with input from JV and GS. All authors provided critical discussion, helped writing the manuscript, and approved its submission.

\section{FUNDING}

AS was supported by the Swedish Research Council (Vetenskapsrådet, Grant No. 2018-01272).

Bartlett, R. (1994). The making of Europe: Conquest, colonization, and cultural change. Princeton: Princeton University Press, 950-1350.

Bauch, J. (1968). Die Problematik der geographischen Reichweite von Jahrringdatierung, dargestellt an Beispielen aus der norddeutschen Tiefebene. Dendrochronologische Untersuchungen an Objekten mittelalterlicher Kunst. Kunstchronik 21, 144-145.

Bauch, J. (1978). Dendrochronology applied to the dating of Dutch, Flemish and German paintings. BAR Int. Ser. 51, 307-314.

Bauch, J., and Eckstein, D. (1970). Dendrochronological Dating of Oak Panels of Dutch Seventeenth-Century Paintings. Stud. Conserv. 1, 45-50. doi: 10.2307/ 1505551

Bauch, J., and Eckstein, D. (1981). Woodbiological investigations on panels of Rembrandt paintings. Wood Sci. Technol. 15, 251-263. doi: 10.1007/bf00350943

Bauch, J., Eckstein, D., and Brauner, G. (1978). Dendrochronologische Untersuchungen an Eichenholztafeln von Rubens-Gemälden. Jahrbuch Berliner Museen 1978, 209-221. doi: 10.2307/4125747

Bauer, S. (2001). Vergängliches Gut auf dem Rhein. Mainzer Holzhandel in römischer Zeit. Schriftenreihe Rheinisches Landesmuseum Trier 2001, 31-42.

Bauer, S. (2009). Vom Großbetrieb zur kleinen Werkstatt-der Strukturwandel im römischen Küferhandwerk aus dendroarchäologischer Sicht. Mainzer Arch. Zeitschr. 8, 21-40.

Becker, B. (1982). Dendrochronologie und Paläoökologie subfossiler Baumstämme aus Flussablagerungen: ein Beitrag zur nacheiszeitlichen Auenentwicklung im südlichen Mitteleuropa. Mitt. Komm. Quartärforsch. Österr. Akad. Wiss. 5:120.

Becker, B. (1993). An 11.000-year German oak and pine dendrochronology for radiocarbon calibration. Radiocarbon 1993, 201-213. doi: 10.1017/ s0033822200013898

Becker, B., and Giertz-Siebenlist, V. (1970). Eine über 1100jaehrige mitteleuropäische Tannenchronologie. Flora 159, 310-346.

Becker, B., Billamboz, A., Egger, H., Gassmann, P., Orcel, A., Orcel, C., et al. (1985). Dendrochronologie in der Ur-und Frühgeschichte. Antiqua 11, 1-68. doi: 10.1515/9783111464589-002

Belasus, M. (2017). "Evidence for medieval shipping along the German Baltic Sea coast from the $12^{\text {th }}$ to the $15^{\text {th }}$ century. Baltic and beyond: Change and continuity in shipbuilding," in Proceedings of the Fourteenth International Symposium on Boat and Ship Archaeology Gdansk 2015, (Gdansk: Boat and Ship Archaeology). 
Belingard, C., Guibal, F., Labbas, V., Shindo, L., Saulnier, M., Serre-Bachet, F., et al. (2019). État des référentiels dendrochronologiques publics de la région ProvenceAlpes-Côte d’Azur Mélčze (Larix decidua Mill.). Aix-en-Provence: Direction régionale des Affaires Cuturelles de Provence-Alpes-Côte d'Azur.

Benguerel, S., Brem, H., Ebersbach, R., Kaiser, M. J., Köninger, J., Leuzinger, U., et al. (2020). Der Orkopf - eine Fundstelle auf der Landesgrenze. Frauenfeld: Portal Kanton Thurgau.

Benguerel, S., Brem, H., Ebneter, I., Ferrer, M., Hartmann, B., Leuzinger, U., et al. (2012). Tasgetium II: die römischen Holzfunde. Archäologie im Thurgau 18. Frauenfeld: Amt für Archäologie Thurgau.

Bernabei, M., Bontadi, J., and Rognoni, G. R. (2010). A dendrochronological investigation of stringed instruments from the collection of the Cherubini Conservatory in Florence, Italy. J. Arch. Sci. 37, 192-200. doi: 10.1016/j.jas.2009. 09.031

Bernabei, M., Bontadi, J., Čufar, K., and Baici, A. (2017). Dendrochronological investigation of the bowed string instruments at the Theatre Museum Carlo Schmidl in Trieste, Italy. J. Cult. Herit. 27, 55-62. doi: 10.1016/j.culher.2016.11. 010

Bernabei, M., Bontadi, J., Quarta, G., Calcagnile, L., and Diodato, M. (2016). The Baptistry of Saint John in Florence: the scientific dating of the timber structure of the dome. Int. J. Archit. Heritage 10, 704-713. doi: 10.1080/15583058.2015. 1109734

Bernabei, M., Bontadi, J., Rea, R., Büntgen, U., and Tegel, W. (2019). Dendrochronological evidence for long-distance timber trading in the Roman Empire. PLoS One 14:e0224077. doi: 10.1371/journal.pone. 0224077

Bernabei, M., Brunetti, M., Macchioni, N., Nocetti, M., and Micheloni, M. (2020). Surveying and Dating the Wooden Roof Structure of St Francis of Assisi Church in Valletta, Malta. Int. J. Archit. Heritage 2020, 1-9.

Bernard, V. (1998). L'homme, le bois et la forêt dans la France du Nord entre le Mésolithique et le Haut Moyen-Age, Vol. 733. Oxford: British Archaeological Reports Ltd.

Bernard, V., Favory, F., and Fiches, J.-L. (2014). Silva et Saltus en Gaule Romaine. Dynamique et gestion des forêts et des zones rurales marginales. Actes du VIIe colloque AGER, Rennes, 27-28 octobre 2004. Besançon: Presses universitaires de Franche-Comté.

Bernard, V., Renaudin, S., and Marguerie, D. (2006). Evidence of trimmed oaks (Quercus sp.) in north western France during the early Middle Ages $\left(9^{\text {th }}\right.$ $11^{\text {th }}$ centuries $\mathrm{AD}$ ). Charcoal analysis: new analytical tools and methods for archaeology. BAR Int. Ser. 1483, 103-108.

Berthold, J. (2009). Die hochmittelalterliche Wassermühle von Elfgen. Mitt. Dtsch. Ges. Archäol. Mittelalt. Neuz. 21, 199-204.

Beuting, D.-H. M., and Klein, P. (2003). The Technique of Dendrochronology as Applied to Stringed Instruments of the Orpheon Foundation. Stuttgart: University of Hamburg.

Beuting, M. (2009). Dendrochronologische Datierung von streichinstrumenten des 15. und 16. Jahrhunderts unter besonderer Berücksichtigung der Geigenbauer linarolo und ciciliano. Technol. Studien Konservierung Restaurierung Forschung Technol. 6, 177-213.

Biel, J. (1995). Der Keltenfürst von Hochdorf. Stuttgart: Theiss.

Billamboz, A. (1988). Jahresringe im Bauholz. Archäol. Württemberg 515:529.

Billamboz, A. (2003). Tree rings and wetland occupation in southwest Germany between 2000 and $500 \mathrm{BC}$ : dendroarchaeology beyond dating in tribute to $\mathrm{FH}$ Schweingruber. 2162-4585. Tree-Ring Res. 59, 37-49.

Billamboz, A. (2014a). Dendrotypology as a key approach of former woodland and settlement developments. Examples from the prehistoric pile dwellings on Lake Constance (Germany). Dendrosymposium 2013:5.

Billamboz, A. (2014b). Regional patterns of settlement and woodland developments: Dendroarchaeology in the Neolithic pile-dwellings on Lake Constance (Germany). Holocene 24, 1278-1287. doi: 10.1177/ 0959683614540956

Billamboz, A., and Köninger, J. (2008). Dendroarchäologische Untersuchungen zur Besiedlungs-und Landschaftsentwicklung im Neolithikum des westlichen Bodenseegebietes: Beobachtungen-Hypothesen-Experimente. Hamburg: K. Wachholtz.

Billamboz, A., and Schlichtherle, H. (1982). Das Holz der "Pfahlbausiedlungen". Archäodendrologie im Projekt Bodensee-Oberschwaben. Denkmalpflege Baden Württemberg Nachrichtenblatt der Landesdenkmalpflege 11, 68-73.
Billamboz, A., and Schöbel, G. (1996). Dendrochronologische Untersuchungen in den spätbronzezeitlichen Pfahlbausiedlungen am nördlichen Ufer des Bodensees. Forschungen Berichte zur Vor Frühgeschichte Baden Württemberg $47,203-221$.

Billamboz, A., and Unz, C. (2006). Dendroarchäologische Untersuchungen in den neolithischen Ufersiedlungen von Hornstaad-Hörnle. Brisbane: Theiss.

Björdal, C. G. (2012). Microbial degradation of waterlogged archaeological wood. J. Cult. Herit. 13, 118-122.

Björklund, J., Arx, G., von, Nievergelt, D., Wilson, R., van den Bulcke, J., et al. (2019). Scientific merits and analytical challenges of tree-ring densitometry. Rev. Geophys. 57, 1224-1264.

Blanchette, R. A., Nilsson, T., Daniel, G., and Abad, A. (1990). Biological degradation of wood. Washington, D.C.: ACS Publications.

Blau, J. (1917). Böhmerwälder hausindustrie und volkskunst. Stuttgart: JG Calve.

Bleicher, N. (2009). Altes Holz in neuem Licht: Berichte zu Ufer-und Moorsiedlungen Südwestdeutschlands. Stuttgart: Materialhefte zur Archäologie in BadenWürttemberg, 83.

Bleicher, N. (2014). Four levels of patterns in tree-rings: an archaeological approach to dendroecology. Veg. Hist. Archaeobot. 23, 615-627. doi: 10.1007/s00334-0130410-6

Bleicher, N., and Harb, C. (2017). Zürich-Parkhaus Opéra. Eine neolithische Feuchtbodenfundstelle. Band 3: Naturwissenschaftliche Analysen und Synthese. Dübendorf: Amt für Raumentwicklung.

Bleicher, N., and Harb, C. (2018). Settlement and social organisation in the late fourth millennium BC in Central Europe: the waterlogged site of ZurichParkhaus Opéra. Antiquity 92, 1210-1230. doi: 10.15184/aqy.2018.109

Blondel, F., Cabanis, M., Girardclos, O., and Grenouillet-Paradis, S. (2018). Impact of carbonization on growth rings: dating by dendrochronology experiments on oak charcoals collected from archaeological sites. Quat. Int. 463, 268-281.

Bockius, R. (2002). Die römerzeitlichen Schiffsfunde von Oberstimm in Bayern: Monographien/Römisch-Germanisches Zentralmuseum, Forschungsinstitut für Vor-und Frühgeschichte. Mainz: Verlag des Roömisch-Germanischen Zentralmuseums.

Bockius, R. (2006). Die spätrömischen Schiffswracks aus Mainz: schiffsarchäologischtechnikgeschichtliche Untersuchung spätantiker Schiffsfunde vom nördlichen Oberrhein. Mainz: Verlag des Roömisch-Germanischen Zentralmuseums.

Bonde, N. (1998). Found in Denmark, but where do they come from. Archaeol. Ireland 12, 24-29.

Bonde, N., Wazny, T., and Tyers, I. (1997). "Where Does the Timber Come From?: Dendrochronological Evidence of the Timber Trade in Northern Europe," in Archaeological Sciences 1995, eds A. Sinclair, E. Slater, and J. Gowlett (Oxford: Oxbow Books), 201-204.

Bräker, O. U., Bill, J., Mühlethaler, B., Schoch, W., Schweingruber, F. H., Haas, A., et al. (1979). Zum derzeitigen stand der nassholzkonservierung. Diskussion der grundlagen und resultate eines von fachlaboratorien 1976-1978 durchgefuehrten methodenvergleiches. Zeitschrift Schweizerische Archaeologie Kunstgeschichte 36, 97-145.

Brandstätter, M. B. (2016). Europäische Holzarten und ihre Verwendung im Musikinstrumentenbau. Vienna: University of Natural Resources and Life Sciences, 99.

Brázdil, R., Stepánková, P., Kyncl, T., and Kyncl, J. (2002). Fir tree-ring reconstruction of March-July precipitation in southern Moravia (Czech Republic), 1376-1996. Clim. Res. 20, 223-239.

Bridge, M. (2012). Locating the origins of wood resources: a review of dendroprovenancing. J. Arch. Sci. 39, 2828-2834.

Bridge, M. C., and Dobbs, C. (1996). Tree-ring studies on the Tudor warship Mary Rose. Tree Rings 1996, 491-496.

Briffa, K. R., Jones, P. D., Schweingruber, F. H., Karlén, W., and Shiyatov, S. G. (1996). Tree-ring variables as proxy-climate indicators: problems with lowfrequency signals, in: Climatic variations and forcing mechanisms of the last 2000 years. Berlin: Springer, 9-41.

Broda, M., and Hill, C. A. S. (2021). Conservation of Waterlogged WoodPast, Present and Future Perspectives. Forests 12:1193. doi: 10.3390/f120 91193

Brown, D. M., Munro, M. A. R., Baillie, M. G. L., and Pilcher, J. R. (1986). Dendrochronology - the absolute Irish standard. Radiocarbon 28, 279-283.

Bucur, V. (2016). "Dendrochronology and wood resources for authentic, historical period musical instruments," in Handbook of Materials for String Musical 
Instruments, ed. V. Bucur (Berlin: Springer), 639-698. doi: 10.1007/978-3-31932080-9_14

Buksnowitz, C., Teischinger, A., Müller, U., Pahler, A., and Evans, R. (2007). Resonance wood [Picea abies (L.) Karst.]-evaluation and prediction of violin makers' quality-grading. J. Acoust. Soc. Am. 121, 2384-2395. doi: 10.1121/1. 2434756

Büntgen, U., Allen, K., Anchukaitis, K. J., Arseneault, D., Boucher, É, Bräuning, A., et al. (2021a). The influence of decision-making in tree ring-based climate reconstructions. Nat. Commun. 12:6. doi: 10.1038/s41467-021-23627-6

Büntgen, U., Bellwald, I., Kalbermatten, H., Schmidhalter, M., Frank, D. C., Freund, H., et al. (2006a). 700 Years of Settlement and Building History in the Lötschental, Switzerland (700 Jahre Siedlungs-und Baugeschichte im Lötschental, Schweiz). Erdkunde 2006, 96-112. doi: 10.3112/erdkunde.2006. 02.02

Büntgen, U., Brázdil, R., Dobrovolný, P., Trnka, M., and Kyncl, T. (2011a). Five centuries of Southern Moravian drought variations revealed from living and historic tree rings. Theoret. Appl. Climatol. 105, 167-180.

Büntgen, U., Brázdil, R., Heussner, K.-U., Hofmann, J., Kontic, R., Kyncl, T., et al. (2011b). Combined dendro-documentary evidence of Central European hydroclimatic springtime extremes over the last millennium. Quat. Sci. Rev. 30, 3947-3959. doi: 10.1016/j.quascirev.2011.10.010

Büntgen, U., Eggertsson, Ó, Wacker, L., Sigl, M., Ljungqvist, F. C., Di Cosmo, N., et al. (2017). Multi-proxy dating of Iceland's major pre-settlement Katla eruption to 822-823 CE. Geology 45, 783-786. doi: 10.1130/g39269.1

Büntgen, U., Frank, D. C., Nievergelt, D., and Esper, J. (2006b). Summer temperature variations in the European Alps, AD 755-2004. J. Clim. 19, 5606-5623.

Büntgen, U., Frank, D., Grudd, H., and Esper, J. (2008). Long-term summer temperature variations in the Pyrenees. Clim. Dyn. 31, 615-631. doi: 10.1007/ s00382-008-0390-x

Büntgen, U., Frank, D., Liebhold, A., Johnson, D., Carrer, M., Urbinati, C., et al. (2009). Three centuries of insect outbreaks across the European Alps. New Phytol. 182, 929-941. doi: 10.1111/j.1469-8137.2009.02825.x

Büntgen, U., Kyncl, T., Ginzler, C., Jacks, D. S., Esper, J., Tegel, W., et al. (2013). Filling the Eastern European gap in millennium-long temperature reconstructions. Proc. Natl. Acad. Sci. U S A. 110, 1773-1778. doi: 10.1073/pnas. 1211485110

Büntgen, U., Tegel, W., Heussner, K.-U., Hofmann, J., Kontic, R., Kyncl, T., et al. (2012). Effects of sample size in dendroclimatology. Clim. Res. 53, 263-269.

Büntgen, U., Tegel, W., Kaplan, J. O., Schaub, M., Hagedorn, F., Bürgi, M., et al. (2014). Placing unprecedented recent fir growth in a European-wide and Holocene-long context. Front. Ecol. Environ. 12, 100-106. doi: 10.1890/130089

Büntgen, U., Tegel, W., Nicolussi, K., McCormick, M., Frank, D., Trouet, V., et al. (2011c). 2500 years of European climate variability and human susceptibility. Science 331, 578-582. doi: 10.1126/science.1197175

Büntgen, U., Trouet, V., Frank, D., Leuschner, H. H., Friedrichs, D., Luterbacher, J., et al. (2010). Tree-ring indicators of German summer drought over the last millennium. Quat. Sci. Rev. 29, 1005-1016.

Büntgen, U., Urban, O., Krusic, P. J., Rybníček, M., Koláŕ, T., Kyncl, T., et al. (2021b). Recent European drought extremes beyond Common Era background variability. Nat. Geosci. 14, 190-196.

Büntgen, U., Wacker, L., Galván, J. D., Arnold, S., Arseneault, D., Baillie, M., et al. (2018). Tree rings reveal globally coherent signature of cosmogenic radiocarbon events in 774 and 993 CE. Nat. Commun. 9, 1-7.

Buras, A., and Wilmking, M. (2015). Correcting the calculation of Gleichläufigkeit. Dendrochronologia 34, 29-30.

Capitani, A., de Deschler-Erb, S., Leuzinger, U., Marti-Grädel, E., and Schibler, J. (2002). Die jungsteinzeitliche Seeufersiedlung Arbon-Bleiche 3, Funde. Frauenfeld: Departement für Erziehung und Kultur des Kantons Thurgau.

Carozza, J.-M., Carozza, L., Valette, P., Llubes, M., Py, V., Galop, D., et al. (2014). The subfossil tree deposits from the Garonne Valley and their implications on Holocene alluvial plain dynamics. Comptes Rendus Geosci. 346, 20-27.

Chabal, L. (1997). Forêts et sociétés en Languedoc (Néolithique final, Antiquité tardive): l'anthracologie, méthode et paléoécologie. Paris: Maison des Sciences de l'Homme.

Christopoulou, A., Gmińska-Nowak, B., Özarslan, Y., and Ważny, T. (2020a). Aegean Trees and Timbers: Dendrochronological Survey of the Island of Symi. Forests 11:1266. doi: 10.3390/f11121266
Christopoulou, A., Ważny, T., Gmińska-Nowak, B., and Moody, J. (2020b). "Dendrochronological research in Greece: A study of Ottoman and Venetian buildings," in Wood in Architecture, 1st Edn, ed. A. Kurek (Cracow: Politechnika Krakowska), 35-44.

Cichocki, O. (2007). Analysis of charcoal samples from Early Bronze Age strata at Tell Arqa: Tell Arqa. Archaeol. Hist. Lebanon 2007, 99-109.

Cichocki, O., and Dworsky, C. (2006). Unterwasserarchäologie in Kärntner Seen. Archäol. Österreichs 17, 90-95.

Clerici, R. (1983). Römische Holzfässer aus Vitudurum. Helvetica Archaeol. 53, 14-24.

Conard, N. J., Serangeli, J., Bigga, G., and Rots, V. (2020). A 300,000-year-old throwing stick from Schöningen, northern Germany, documents the evolution of human hunting. Nat. Ecol. Evol. 4, 690-693. doi: 10.1038/s41559-020-1139-0

Conedera, M., Tinner, W., Neff, C., Meurer, M., Dickens, A. F., and Krebs, P. (2009). Reconstructing past fire regimes: methods, applications, and relevance to fire management and conservation. Quat. Sci. Rev. 28, 555-576.

Cook, E. R., and Kairiukstis, L. A. (2013). Methods of dendrochronology: applications in the environmental sciences. New York, NY: Springer Science \& Business Media.

Cook, E. R., Seager, R., Kushnir, Y., Briffa, K. R., Büntgen, U., Frank, D., et al. (2015). Old World megadroughts and pluvials during the Common Era. Sci. Adv. 1:e1500561. doi: 10.1126/sciadv.1500561

Corona, C., Guiot, J., Edouard, J. L., Chalié, F., Büntgen, U., Nola, P., et al. (2010). Millennium-long summer temperature variations in the European Alps as reconstructed from tree rings. Clim. Past 6, 379-400.

Crone, A., and Fawcett, R. (1998). Dendrochronology, Documents and the Timber Trade: New Evidence for the Building History of Stirling Castle, Scotland. Mediev. Archaeol. 42, 68-87. doi: 10.1080/00766097.1998.11735618

Croutsch, C., Goepfert, S., and Adam, A.-M. (eds) (2020). Les puits de la Protohistoire dans l'est de la France. Mémoires d'Archéol. Grand Est 6:256.

Croutsch, C., Tegel, W., and Lefranc, P. (2019). Dambach-la-Ville (Elsass, Frankreich): Ein Beitrag zur Siedlungsgeschichte eines Dorfes aus der zweiten Hälfte des 5. Jahrtausends V. Chr, 7th Edn. Kerpen-Loogh: Deutsche Gesellschaft für Ur- und Frühgeschichte, 91-104.

Crumlin-Pedersen, O., and Trakadas, A. (2003). Hjortspring: a pre-Roman Iron-Age warship in context. Norway: Viking Ship Museum.

Crumlin-Pedersen, O., Hirte, C., and Jensen, K. (1997). Viking-age ships and shipbuilding in Hedeby/Haithabu and Schleswig. Viking Ship Museum. Norway: Viking Ship Museum.

Čufar, K., Beuting, M., Demšar, B., and Merela, M. (2017). Dating of violins-the interpretation of dendrochronological reports. J. Cult. Herit. 27, 44-54.

Čufar, K., Gričar, J., Zupančič, M., Koch, G., and Schmitt, U. (2008c). Wood anatomy, cell-wall structure and topochemistry of waterlogged archaeological wood aged 5,200 and 4,500 years. IAWA J. 29, 55-68.

Čufar, K., Horvat, J., Tolar, T., Berden, T., and Merela, M. (2019). Research potential of wood of barrels from Roman water wells. Les/Wood 68, 47-60.

Čufar, K., Luis, M., de Eckstein, D., and Kajfež-Bogataj, L. (2008a). Reconstructing dry and wet summers in SE Slovenia from oak tree-ring series. Int. J. Biometeorol. 52, 607-615. doi: 10.1007/s00484-008-0153-8

Čufar, K., Luis, M., de Zupančič, M., and Eckstein, D. (2008b). A 548-year tree-ring chronology of oak (Quercus spp.) for southeast Slovenia and its significance as a dating tool and climate archive. Tree Ring Res. 64, 3-15.

Čufar, K., Merela, M., and Erič, M. (2014). A Roman barge in the Ljubljanica river (Slovenia): wood identification, dendrochronological dating and wood preservation research. J. Archaeol. Sci. 44, 128-135. doi: 10.1016/j.jas.2014.01. 024

Čufar, K., Tegel, W., Merela, M., Kromer, B., and Velušček, A. (2015). Eneolithic pile dwellings south of the Alps precisely dated with tree-ring chronologies from the north. Dendrochronologia 35, 91-98.

Daly, A. (2007). The Karschau ship, Schleswig-Holstein: Dendrochronological results and timber provenance. Int. J. Naut. Archaeol. 36, 155-166. doi: 10.1111/ j.1095-9270.2006.00103.x

Daly, A., and Nymoen, P. (2008). The Břle ship, Skien, Norway-Research history, dendrochronology and provenance. Int. J. Naut. Archaeol. 37, 153-170. doi: 10.1111/j.1095-9270.2007.00157.x

Daly, A., and Streeton, N. L. W. (2017). Non-invasive dendrochronology of latemedieval objects in Oslo: refinement of a technique and discoveries. Appl. Physics A 123, 1-12. 
Daly, A., Domínguez-Delmás, M., and van Duivenvoorde, W. (2021). Batavia shipwreck timbers reveal a key to Dutch success in 17th-century world trade. PLoS One 16:e0259391. doi: 10.1371/journal.pone.0259391

Deforce, K. (2017). Wood use in a growing medieval city. The overexploitation of woody resources in Ghent (Belgium) between the $10^{\text {th }}$ and $12^{\text {th }}$ century AD. Quat. Int. 458, 123-133. doi: 10.1016/j.quaint.2016.09.059

Deforce, K., and Haneca, K. (2015). Tree-ring analysis of archaeological charcoal as a tool to identify past woodland management: The case from a $14^{\text {th }}$ century site from Oudenaarde (Belgium). Quat. Int. 366, 70-80. doi: 10.1016/j.quaint.2014. 05.056

Deforce, K., Bastiaens, J., Crombé, P., Deschepper, E., Haneca, K., Laloo, P., et al. (2020). Dark Ages woodland recovery and the expansion of beech: a study of land use changes and related woodland dynamics during the Roman to Medieval transition period in northern Belgium. Netherlands J. Geosci. 2020:99.

Delfs, J. (1985). Die Flößerei in Deutschland und ihre Bedeutung für die Volks-und Forstwirtschaft. Flößerei in Deutschland, 34-54.

Domínguez-Delmás, M. (2020). Seeing the forest for the trees: New approaches and challenges for dendroarchaeology in the $21^{\text {st }}$ century. Dendrochronologia 62:125731. doi: 10.1016/j.dendro.2020.125731

Domínguez-Delmás, M., Bossema, F. G., Dorscheid, J., Coban, S. B., HallAquitania, M., Batenburg, K. J., et al. (2021a). X-ray computed tomography for non-invasive dendrochronology reveals a concealed double panelling on a painting from Rubens' studio. PLoS One 16:e255792. doi: 10.1371/journal. pone. 0255792

Domínguez-Delmás, M., Bridge, M., and Visser, A. S. Q. (2021b). Dendrochronological analysis of an english chest: Contributing to knowledge about wood supply and chest production in $16^{\text {th }}$ century England. Dendrochronologia 67:125828.

Domínguez-Delmás, M., Driessen, M., García-González, I., van Helmond, N., Visser, R., and Jansma, E. (2014). Long-distance oak supply in mid-2 $2^{\text {nd }}$ century AD revealed: the case of a Roman harbour (Voorburg-Arentsburg) in the Netherlands. J. Arch. Sci. 41, 642-654. doi: 10.1016/j.jas.2013. 09.009

Domínguez-Delmás, M., Nayling, N., Ważny, T., Loureiro, V., and Lavier, C. (2013). Dendrochronological dating and provenancing of timbers from the Arade 1 Shipwreck, Portugal. Int. J. Naut. Archaeol. 42, 118-136.

Domínguez-Delmás, M., Rich, S., Daly, A., Nayling, N., and Haneca, K. (2019). Selecting and Sampling Shipwreck Timbers for Dendrochronological Research: practical guidance. Int. J. Naut. Archaeol. 48, 231-244. doi: 10.1111/1095-9270. 12329

Domínguez-Delmás, M., Trapaga-Monchet, K., Nayling, N., and GarcíaGonzález, I. (2017). Natural hazards and building history: Roof structures of Segovia cathedral (Spain) reveal its history through treering research. Dendrochronologia 46, 1-13. doi: 10.1016/j.dendro.2017.09. 002

Domínguez-Delmás, M., van Daalen, S., Alejano-Monge, R., and Wazny, T. (2018). Timber resources, transport and woodworking techniques in post-medieval Andalusia (Spain): Insights from dendroarchaeological research on historic roof structures. J. Arch. Sci. 95, 64-75. doi: 10.1016/j.jas.2018.05.002

Donnart, K., Tegel, W., Muigg, B., Ferrier, A., Ravry, D., Pescher, B., et al. (2019). De grčs et de chêne: l'enceinte néolithique de La Villeneuve-au-Châtelot (Aube), «Les Communes-La Pičce des Quarante». Exploitation et mise en oeuvre des ressources. Soc. Préhistorique de France 3, 175-184.

Douglass, A. E. (1909). Weather cycles in the growth of big trees. Monthly Weather Rev. 37, 225-237. doi: 10.1175/1520-0493(1909)37[225d:wcitgo]2.0.co;2

Douglass, A. E. (1920). Evidence of climatic effects in the annual rings of trees. Ecology 1, 24-32. doi: 10.2307/1929253

Douglass, A. E. (1935). Dating Pueblo Bonito and other ruins of the Southwest. Washington, D.C: National Geographic Society.

Douglass, A. E. (1941). Crossdating in Dendrochronology. J. For. 39, 825-831. doi: 10.1093/jof/39.10.825

Dufraisse, A., Coubray, S., Girardclos, O., Nocus, N., Lemoine, M., Dupouey, J.-L., et al. (2018). Anthraco-typology as a key approach to past firewood exploitation and woodland management reconstructions. Dendrological reference dataset modelling with dendro-anthracological tools. Quat. Int. 463, 232-249. doi: 10.1016/j.quaint.2017.03.065

Dvorská, J., Heußner, K.-U., and Polácek, L. (1999). Zum Stand der Dendrochronologie in Mikulcice. Mähren: Akademie der Wissenschaften.
Eckstein, D. (1978). Dendrochronological dating of the medieval settlement of Haithabu (Hedeby). Dendrochronol. Eur. 51, 267-274.

Eckstein, D., and Bauch, J. (1969). Beitrag zur Rationalisierung eines dendrochronologischen Verfahrens und zur Analyse seiner Aussagesicherheit. Forstwissenschaftliches Centralblatt 88, 230-250.

Eckstein, D., and Pilcher, J. R. (1990). "Dendrochronology in western Europe," in Methods of Dendrochronology: Applications in the Environmental Sciences, eds L. A. Kairiukstis and E. R. Cook (Boston, MA: International Institute for Applied Systems Analysis, Kluwer Academic Publishers), 1113.

Eckstein, D., and Wrobel, S. (1983). Dendrochronologie in Europa. Dendrochronologia 1, 9-17.

Edvardsson, J., Corona, C., Mažeika, J., Pukienë, R., and Stoffel, M. (2016a). Recent advances in long-term climate and moisture reconstructions from the Baltic region: Exploring the potential for a new multi-millennial treering chronology. Quat. Sci. Rev. 131, 118-126. doi: 10.1016/j.quascirev.2015. 11.005

Edvardsson, J., Seim, A., Davies, J., and Vander Auwera, J. (2021). The rediscovery of an Adoration of the Shepherds by Jacques Jordaens: a multidisciplinary approach combining dendroarchaeology and art history. Herit. Sci. 9:39. doi: 10.1186/s40494-021-00512-5

Edvardsson, J., Stoffel, M., Corona, C., Bragazza, L., Leuschner, H. H., Charman, D. J., et al. (2016b). Subfossil peatland trees as proxies for Holocene palaeohydrology and palaeoclimate. Earth-Sci. Rev. 163, 118-140. doi: 10.1016/ j.earscirev.2016.10.005

Eißing, T. (2005). "Zur Anwendung der Dendrochronologie in der Bauforschung: Einige kritische Anmerkungen," in Bauforschung - eine kritische Revision, eds J. Cramer, P. Goralcyk, and D. Schumann (Berlin: Lukas), 297-328.

Eißing, T. (2015). Dendrochronologie und Bauforschung: Ein interdisziplinärer Dialog. Dresden: Koldewey-Gesellschaft, 93-104.

Eißing, T., and Dittmar, C. (2011). Timber transport and dendroprovenancing in Thuringia and Bavaria. Tree Rings Art Archaeol. 137-149.

Eißing, T., Furrer, B., King, S., Knapp, U., Krämer, A., Lohrum, B., et al. (2012). Vorindustrieller Holzbau in Südwestdeutschland und der deutschsprachigen Schweiz Terminologie und Systematik. Südwestdeutsche Beiträge zur historischen Bauforschung.

Elburg, R., Hein, W., Probst, A., and Walter, P. (2015). Field trials in Neolithic woodworking. (Re)Learning to use Early Neolithic stone adzes. Archaeol. Craft. Experiences Exp. Tradit. Skills Handicrafts Archaeol. Open Air Museums Eur. 5, $62-77$.

Ellenberg, H. (1996). Vegetation Mitteleuropas mit den Alpen in ökologischer, dynamischer und historischer Sicht. 5. Stuttgart: stark veränd. u. verb.

Ellmers, D. (1972). Frühmittelalterliche Handelsschiffahrt in Mittel-und Nordeuropa. Neumüster: Wachholtz.

Ellmers, D. (1985). Flößerei in Vorgeschichte, Römerzeit und Mittelalter. Stuttgart: Flösserei in Deutschland, 12-33.

Endlich, C., and Lässig, H.-C. (2007). Holzverbrauch in großen Mengen Moorwege der frühesten Bauform. Oldenburg 143-147.

Englert, A., and Crumlin-Pedersen, O. (2015). Large Cargo Ships in Danish Waters 1000-1250: Evidence of Specialised Merchant Seafaring Prior to the Hanseatic Period. Oslo: Viking Ship Museum.

Épaud, F. (2007). De la charpente romane à la charpente gothique en Normandie: évolution des techniques et des structures de charpenterie du XIIe au XIIIe sičcles. Publications du CRAHM.

Epperlein, S. (1993). "Waldnutzung, Waldstreitigkeiten und Waldschutz in Deutschland im hohen Mittelalter. 2. Hälfte 11. Jahrhundert bis ausgehendes 14," in Jahrhundert Vierteljahrschrift für Sozial-und Wirtschaftsgeschichte Beihefte 109. Stuttgart: Steiner.

Eronen, M., Zetterberg, P., Briffa, K. R., Lindholm, M., Meriläinen, J., and Timonen, M. (2002). The supra-long Scots pine tree-ring record for Finnish Lapland: Part 1, chronology construction and initial inferences. Holocene 12, 673-680. doi: 10.1191/0959683602hl580rp

Esper, J., Düthorn, E., Krusic, P. J., Timonen, M., and Büntgen, U. (2014). Northern European summer temperature variations over the Common Era from integrated tree-ring density records. J. Quat. Sci. 29, 487-494.

Esper, J., Frank, D. C., Wilson, R. J. S., and Briffa, K. R. (2005). Effect of scaling and regression on reconstructed temperature amplitude for the past millennium. Geophys. Res. Lett. 2005, 32. 
Esper, J., Frank, D., Büntgen, U., Verstege, A., Luterbacher, J., and Xoplaki, E. (2007). Long-term drought severity variations in Morocco. Geophys. Res. Lett. 34:844.

Esper, J., Konter, O., Klippel, L., Krusic, P. J., and Büntgen, U. (2021). Preinstrumental summer precipitation variability in northwestern Greece from a high-elevation Pinus heldreichii network. Int. J. Climatol. 2828-2839. doi: 10.1002/joc.6992

Esper, J., Krusic, P. J., Ljungqvist, F. C., Luterbacher, J., Carrer, M., Cook, E., et al. (2016). Ranking of tree-ring based temperature reconstructions of the past millennium. Quat. Sci. Rev. 145, 134-151. doi: 10.1016/j.quascirev.2016.05.009

Esper, J., Krusic, P. J., Peters, K., and Frank, D. (2009). Exploration of longterm growth changes using the tree-ring detrending program "Spotty". Dendrochronologia 27, 75-82. doi: 10.1016/j.dendro.2008.07.003

Falk, A. (2003). Warentransport im Mittelalter und in der Frühen Neuzeit. Transportwege-Transportmittel-Infrastruktur. Vorträge der Sitzung in Hamburg, 21. und 22. Mai 2002. Mitteilungen der Deutschen Gesellschaft für Archäologie des Mittelalters und der Neuzeit 14, 7-8.

Fansa, M. (1992). Moorarchäologie in Niedersachsen. Archäol. Mitt. Nordwestdtschl 5-21.

Fermé, L. C., Mineo, M., Ntinou, M., Remolins, G., Mazzucco, N., and Gibaja, J. F. (2021). Woodworking technology during the early Neolithic: First results at the site of La MARMOTTA (Italy). Quat. Int. 593, 399-406. doi: 10.1016/j.quaint. 2020.10.067

Finsterbusch, E., and Thiele, W. (1987). Vom Steinbeil zum Sägegatter: ein Streifzug durch die Geschichte der Holzbearbeitung. Leipzig: VEB Fachbuchverlag.

Fletcher, J. M. (1975). Relation of abnormal earlywood in oaks to dendrochronology and climatology. Nature 254, 506-507.

Fraiture, P. (2009). Contribution of dendrochronology to understanding of wood procurement sources for panel paintings in the former Southern Netherlands from $1450 \mathrm{AD}$ to $1650 \mathrm{AD}$. Dendrochronologia 27, 95-111. doi: 10.1016/j. dendro.2009.06.002

Fraiture, P., and Dubois, H. (2011). "Dendrochronological and technological examination of painting supports. The case of Rubens's studio practice," in Tree Rings, Art, Archaeology. Proceedings of a conference.

Freese, B. (2003). Coal: A human history. Perseus: Cambridge.

Frei-Stolba, R. (2017). Holzfässer: Studien zu den Holzfässern und ihren: Inschriften im römischen Reich mit Neufunden und Neulesungen der Fassinschriften aus Oberwinterthur. Baudirektion Kanton Zürich: Amt für Raumentwicklung, Kantonsarchäologie.

Friedrich, M., Kromer, B., Spurk, M., Hofmann, J., and Kaiser, K. F. (1999). Paleoenvironment and radiocarbon calibration as derived from Lateglacial/Early Holocene tree-ring chronologies. Quat. Int. 61, 27-39.

Friedrich, M., Remmele, S., Kromer, B., Hofmann, J., Spurk, M., Kaiser, K. F., et al. (2004). The 12,460-year Hohenheim oak and pine tree-ring chronology from central Europe-a unique annual record for radiocarbon calibration and paleoenvironment reconstructions. Radiocarbon 46, 1111-1122. doi: 10.1017/ s003382220003304x

Fritts, H. (1976). Tree rings and climate. London: Academic Press Inc.

Goldammer, G. (1998). Die Beeinflussung der norddeutschen Kulturlandschaft durch historische Binnenkanäle: dargestellt am Beispiel des Schaale-Kanals. Deutsches Schiffahrtsarchiv 21, 65-81.

Gomolka, J. (1992). Dendrochronologische Untersuchungen aus der Sicht der Denkmalpflege. Niedersächsische Denkmalpflege 96-107.

Goodman, W. L. (1963). The history of woodworking tools. G. Bell.

Grabner, M., Buchinger, G., and Jeitler, M. (2018). Stories about building history told by wooden elements-case studies from Eastern Austria. Int. J. Archit. Heritage 12, 178-194. doi: 10.1080/15583058.2017.1372824

Grabner, M., Wächter, E., Nicolussi, K., Bolka, M., Sormaz, T., Steier, P., et al. (2021). Prehistoric salt mining in Hallstatt, Austria. New chronologies out of small wooden fragments. Dendrochronologia 66:125814. doi: 10.1016/j.dendro. 2021.125814

Grabner, M., Wimmer, R., Gindl, W., and Nicolussi, K. (2001). “A 3474-year alpine tree-ring record from the Dachstein, Austria," in International Conference Tree Rings and People. Davos, 22-26 September 2001, Abstracts, eds M. Kaennel Dobbertin and O. U. Bräker (Birmensdorf: Swiss Federal Research Institute WSL).

Greber, J. M. (1987). Die Geschichte des Hobels: von der Steinzeit bis zur Entstehung der Holzwerkzeugfabriken im frühen 19. Schäfer: im Verlag Th.
Greig, J. (1981). The investigation of a medieval barrel-latrine from Worcester. J. Arch. Sci. 8, 265-282. doi: 10.1016/0305-4403(81)90003-0

Grosser, D. (1977). Die Hölzer Mitteleuropas. Berlin: Ein mikrophotographischer Lehratlas, 208.

Grudd, H. (2008). Torneträsk tree-ring width and density AD 500-2004: a test of climatic sensitivity and a new 1500 -year reconstruction of north Fennoscandian summers. Clim. Dyn. 31, 843-857.

Grudd, H., Briffa, K. R., Karlén, W., Bartholin, T. S., Jones, P. D., and Kromer, B. (2002). A 7400-year tree-ring chronology in northern Swedish Lapland: natural climatic variability expressed on annual to millennial timescales. Holocene 12 , 657-665. doi: 10.1191/0959683602hl578rp

Hafner, A., Dolbunova, E., Mazurkevich, A., Pranckenaite, E., and Hinz, M. (2020). Settling Waterscapes in Europe. The Archaeology of Neolithic \& Bronze Age Pile-Dwellings. Propylaeum: Heidelberg University Library.

Hafner, A., Reich, J., Ballmer, A., Bolliger, M., Antolín, F., Charles, M., et al. (2021). First absolute chronologies of neolithic and bronze age settlements at Lake Ohrid based on dendrochronology and radiocarbon dating. J. Arch. Sci. Rep. 38:103107. doi: 10.1016/j.jasrep.2021.103107

Hagendorn, A., and Bouchet, F. (2003). Zur Frühzeit von Vindonissa: Auswertung der Holzbauten der Grabung Windisch-Breite 1996-1998. Aargauische Kantonsarchäologie.

Hakelberg, D. (1996). A $14^{\text {th }}$-century vessel from Immenstaad (Lake Constance, southern Germany). Int. J. Naut. Archaeol. 25, 224-233. doi: 10.1111/j.10959270.1996.tb00772.x

Hakozaki, M., Miyake, F., Nakamura, T., Kimura, K., Masuda, K., and Okuno, M. (2018). Verification of the annual dating of the $10^{\text {th }}$ Century Baitoushan Volcano eruption based on an AD 774-775 radiocarbon spike. Radiocarbon 60, 261-268.

Haneca, K., and Beeckman, H. (2005). Growth trends reveal the forest structure during Roman and Medieval times in Western Europe: a comparison between archaeological and actual oak ring series (Quercus robur and Quercus petraea). Ann. For. Sci. 62, 797-805.

Haneca, K., and Deforce, K. (2020). Wood use in early medieval weapon production. Archaeol. Anthropol. Sci. 12, 1-16. doi: 10.17054/memes.2011. 19.1.1

Haneca, K., and van Daalen, S. (2017). The roof is on fire! A dendrochronological reconstruction of the restoration of the Basilica of Our Lady in Tongeren (Belgium). Dendrochronologia 44, 153-163. doi: 10.1016/j.dendro.2017. 05.001

Haneca, K., Čufar, K., and Beeckman, H. (2009). Oaks, tree-rings and wooden cultural heritage: a review of the main characteristics and applications of oak dendrochronology in Europe. J. Arch. Sci. 36, 1-11.

Haneca, K., Deforce, K., Boone, M. N., van Loo, D., Dierick, M., van Acker, J., et al. (2012). X-ray sub-micron tomography as a tool for the study of archaeological wood preserved through the corrosion of metal objects. Archaeometry 54, 893-905.

Haneca, K., Wazny, T., van Acker, J., and Beeckman, H. (2005). Provenancing Baltic timber from art historical objects: success and limitations. J. Arch. Sci. $32,261-271$.

Harzenetter, M., Haspel, J., Hesse, F. P., Karg, D., and Sandmeier, J. (2016). Leitbild Denkmalpflege: Zur Standortbestimmung der Denkmalpflege heute = Conservation in Germany; the principles of conservation in today's world, 2nd Edn. Wiesbaden: Imhof.

Hausrath, H. (1982). Geschichte des deutschen Waldbaus: von seinen Anfängen bis 1850. Frankfurt: Hochschulverlag.

Hayen, H. (1990). Moorarchäologie-Möglichkeiten und Folgerungen. Niedersächs. Akad. Geowiss. 5, 30-41.

Helama, S., Timonen, M., Holopainen, J., Ogurtsov, M. G., Mielikäinen, K., Eronen, M., et al. (2009). Summer temperature variations in Lapland during the Medieval Warm Period and the Little Ice Age relative to natural instability of thermohaline circulation on multi-decadal and multi-centennial scales. J. Quat. Sci. 24, 450-456. doi: 10.1002/jqs.1291

Helama, S., Timonen, M., Lindholm, M., Meriläinen, J., and Eronen, M. (2005). Extracting long-period climate fluctuations from tree-ring chronologies over timescales of centuries to millennia. Int. J. Climatol. 25, 1767-1779. doi: 10. 1002/joc. 1215

Henne, R. (2005). Flöße von der Oberweser: Und Immer Stromab an Kuhlbaum und Schnepper. Holzminden: Mitzkat, 144. 
Herzig, F. (2009). Dendroarchäologie: Mensch und Umwelt-eine Wechselwirkung, eingraviert in Holz (Dendroarchaeology: man and environment-an interaction engraved in wood). Bericht der bayerischen Bodendenkmalpflege 50, 225-236.

Herzig, F., and Berg-Hobohm, S. (2010). Römische Fass- und Kastenbrunnen im Vicus von Munningen - Ausgrabungen im Bereich der neunen Ortsumfahrung. Denkmalpflege Informationen 145, 11-13.

Herzig, F., and Seim, A. (2011). Dendrochronologische Untersuchungen an Holzkohlen der mittelbronzezeitlichen Wallanlage von Bernstorf. Bericht der bayerischen Bodendenkmalpflege 52:2012.

Herzig, F., Rauh, A., and Theurer, C. (2013). Eine Villa Rustica mit Brunnen in Burgweintig. Das Archäologische Jahr Bayern 2012, 89-91.

Heussner, K. U. (1985). Zwei bronzezeitliche Scheibenräder von Kühlungsborn, Kreis Bad Doberan. Bodendenkmalpflege Mecklenburg Vorpommern 33, 125131.

Heussner, K.-U. (2015). De houtvoorziening van Amsterdam uit Scandinavië en het Baltisch gebied: gezien vanuit dendrochronologisch perspectief (circa 1500-1700). Bull. KNOB 114, 132-143.

Hillam, J., and Tyers, I. (1995). Reliability and repeatability in dendrochronological analysis: tests using the fletcher archive of panel-painting data. Archaeoometry 2, 395-405. doi: 10.1111/j.1475-4754.1995.tb00752.x

Hoffmann, G., and Schnall, U. (2005). The Bremen Cog, A portrait of a ship's type. Maritime Life Tradit. 27, 12-25.

Hoffsummer, P. (2009). Roof Frames from the $11^{\text {th }}$ to the $19^{\text {th }}$ Century: Typology and development in Northern France and in Belgium: Analysis of CRMH Documentation. Belgium: Brepols Publishers.

Hollstein, E. (1965). Jahrringchronologische datierung von Eichenhölzern ohne Waldkante. Bonner Jahrbücher 165, 12-27.

Hollstein, E. (1967). Jahrringchronologien aus vor-romischer und romischer zeit. Germania 45, 70-83.

Hollstein, E. (1980). Mitteleuropäische Eichenchronologie. Mainz: Philipp Von Zabern.

Holzhauser, H., Magny, M., and Zumbuühl, H. J. (2005). Glacier and lake-level variations in west-central Europe over the last 3500 years. Holocene 15, 789-801.

Höneisen, M., Schiile, B. A., Studer, D., and Oechslin, C. (1989). Die jungsteinzeitlichen Räder der Schweiz: die ältesten Europas. Das Rad Schweiz vom 3, 13-22.

Hönes, E.-R. (2005). Das europäische Übereinkommen zum Schutz des archäologischen Erbes vom 16. 1. 1992. Natur Recht 27, 751-757. doi: 10.1007/ s10357-005-0801-2

Houbrechts, D. (2007). Le logis en pans de bois dans les villes du bassin de la Meuse moyenne (XVe-XVlIe sičcle): apport de l'archéologie du bâti. Bull. Monumental 165, 175-194. doi: 10.3406/bulmo.2007.1440

Huber, B. (1941). Aufbau einer mitteleuropäischen Jahrring-Chronologie: vorgetragen in der Sitzung am 6. September 1940. Meschede: Sauerländer.

Huber, B. (1963). Das Watterbacher Haus im Odenwald, ein wichtiges Brückenstück unserer tausendjährigen Eichenchronologie. FloristischSoziologische Arbeitsgemeinschaft: Mitteilungen der Floristisch-Soziologischen Arbeitsgemeinschaft 10, 256-260.

Huber, B., and Giertz-Siebenlist, V. (1969). Unsere tausendjährige EichenJahrringchronologie durchschnittlich. Springer 57, 10-150.

Huber, B., and Holdheide, W. (1942). Jahrringchronologische Untersuchungen an Hölzern der bronzezeitlichen Wasserburg Buchau am Federsee. Ber. Dtsch. bot. Ges. 60, 261-283.

Huber, B., and Jazewitsch, W. V. (1958). Jahrringuntersuchungen an Pfahlbauhölzern. Flora oder Allgemeine Botanische Zeitung 146, 445-471. doi: 10.1016/s0367-1615(17)32530-2

Huber, B., Merz, W., and Müller-Beck, H. (1963). Jahrringchronologische Synchronisierung der jungsteinzeitlichen Siedlungen. Germania: ThayngenWeier und Burgäschisee-Süd und-Südwest.

Irsigler, F. (1992). "Teutschlands hochschlagende Pulsader. Zur wirtschaftlichen Bedeutung des Rheins bis zum frühen 19. Jahrhundert," in Vom Zauber des Rheins ergriffen Zur Entdeckung der Rheinlandschaft, eds K. Honnef, K. Weschenfelder, and I. Haberland (München: Klinkhardt \& Biermann), 67-80.

Jansma, E. (1995). RemembeRINGs: the development and application of local and regional tree-ring chronologies of oak for the purposes of archaeological and historical research in the Netherlands. Ph. D. thesis. Amersfoort: Rijksdienst voor het Oudheidkundig Bodemonderzoek.
Jansma, E. (2020). Hydrological disasters in the NW-European Lowlands during the first millennium AD: a dendrochronological reconstruction. Netherlands J. Geosci. 99:10.

Jansma, E., Haneca, K., and Kosian, M. (2014). A dendrochronological reassessment of three Roman boats from Utrecht (the Netherlands): evidence of inland navigation between the lower-Scheldt region in Gallia Belgica and the limes of Germania inferior. J. Arch. Sci. 50, 484-496. doi: 10.1016/j.jas.2014.07. 019

Jeute, G. H. (2015). Zur Verbreitung der hochmittelalterlichen Mühle aus archäologischer Sicht. Wassermühlen und Wassernutzung im mittelalterlichen Ostmitteleuropa. Forschungen zur Geschichte und Kultur des östlichen Mitteleuropa 50, 269-277.

Jevšenak, J., Goršiæ, E., Stojanoviæ, D. B., Matoviæ, B., and Levanič, T. (2019). Sapwood characteristics of Quercus robur species from the south-western part of the Pannonian Basin. Dendrochronologia 54, 64-70. doi: 10.1016/j.dendro. 2019.02.006

Johansen, H. C. (1983). Shipping and trade between the Baltic Area and Western Europe 1784-95. Denmark: Univ. Pr. of Southern Denmark.

Jull, A. T., Panyushkina, I. P., Lange, T. E., Kukarskih, V. V., Myglan, V. S., Clark, K. J., et al. (2014). Excursions in the $14 \mathrm{C}$ record at AD 774-775 in tree rings from Russia and America. Geophys. Res. Lett. 41, 3004-3010.

Jull, A. T., Panyushkina, I. P., Molnár, M., Varga, T., Wacker, L., Brehm, N., et al. (2021). Rapid 14 C excursion at 3372-3371 BCE not observed at two different locations. Nat. Commun. 12, 1-3.

Jull, A. T., Panyushkina, I., Miyake, F., Masuda, K., Nakamura, T., Mitsutani, T., et al. (2018). More rapid 14C excursions in the tree-ring record: a record of different kind of solar activity at about 800 BC? Radiocarbon 60, 1237-1248. doi: $10.1017 /$ rdc.2018.53

Kaczka, R. J., Spyt, B., Janecka, K., Niedźwiedź, T., and Bednarz, Z. (2016). Climate reconstruction from tree-rings in the Tatra mountains, in: Flood Risk in the Upper Vistula Basin. Berlin: Springer, 209-229.

Kaplan, J. O., Krumhardt, K. M., and Zimmermann, N. (2009). The prehistoric and preindustrial deforestation of Europe. Quat. Sci. Rev. 28, 3016-3034. doi: 10.1016/j.scitotenv.2006.08.013

Kapteyn, J. C. (1914). Tree-growth and meteorological factors. Recueil des Travaux Botaniques Néerlandais 11, 70-93.

Kelly, P. M., Leuschner, H. H., Briffa, K. R., and Harris, I. C. (2002). The climatic interpretation of pan-European signature years in oak ring-width series. Holocene 12, 689-694. doi: 10.1191/0959683602hl582rp

Kipfer, B. A. (2000). Encyclopedic dictionary of archaeology. Berlin: Springer Science \& Business Media.

Kirby, D. (2014). Northern Europe in the early modern period: the Baltic world 1492-1772. London: Routledge.

Klein, A., Nemestothy, S., Kadnar, J., and Grabner, M. (2014). Dating furniture and coopered vessels without waney edge-Reconstructing historical wood-working in Austria with the help of dendrochronology. Dendrochronologia 32, 90-96. doi: 10.1016/j.dendro.2013.11.002

Klein, P. (1985). Dendrochronologische Untersuchungen an Gemäldetafeln und Musikinstrumenten. Dendrochronologia 3, 25-44.

Klein, P. (1986). Age determinations based on dendrochronology. Sci. Examinat. Easel Paintings 225-267.

Klein, P. (1996). Dendrochronology and violins. Dendrochronological and woodbiological investigations on string instruments. Newsletter Br. Violin Making Assoc. 4, 12-25. doi: 10.1177/000313136601600116

Klein, P. (1998). Dendrochronological analyses of art objects, in: Scientific Detection of Fakery in Art. Photonics West '98 Electronic Imaging. San Jose, CA: SPIE, 21-30.

Klein, P., and Wazny, T. (1991). Dendrochronological analyses of paintings of Gdansk painters of the $15^{\text {th }}$ to the $17^{\text {th }}$ century. Dendrochronologia $181-191$.

Klippel, L., Krusic, P. J., Brandes, R., Hartl, C., Belmecheri, S., Dienst, M., et al. (2018). A 1286-year hydro-climate reconstruction for the Balkan Peninsula. Boreas 47, 1218-1229. doi: 10.1111/bor.12320

Knibbe, B. (2008). PAST4-Personal Analysis System for Treering Research Version 4.5. SCIEM.

Koláŕ, T., Dobrovolný, P., Szabó, P., Mikita, T., Kyncl, T., Kyncl, et al. (2021). Wood species utilization for timber constructions in the Czech lands over 
the period 1400-1900. Dendrochronologia 2021:125900. doi: 10.1016/j.dendro. 2021.125900

Kolár, T., Kyncl, T., and Rybníček, M. (2012). Oak chronology development in the Czech Republic and its teleconnection on a European scale. Dendrochronologia 30, 243-248. doi: 10.1016/j.dendro.2012.02.002

Kolář, T., Rybníček, M., and Tegel, W. (2013). Dendrochronological evidence of cockchafer (Melolontha sp.) outbreaks in subfossil tree-trunks from Tovačov (CZ Moravia). Dendrochronologia 31, 29-33. doi: 10.1016/j.dendro.2012.04.004

Kolchin, B. A. (1962). Dendrochronology of Novgorod. (Dendrokhronologiya Novgoroda). Sov. Archeol. 1, 113-139.

Krąpiec, M. (2001). Holocene dendrochronological standards for subfossil oaks from the area of Southern Poland. Stud. Quat. 18, 47-53.

Kretschmer, S., Viol, P., Stäuble, H., Herbig, C., Muigg, B., Tegel, W., et al. (2016). Der Fundplatz Drossdorf im Tagebaufeld Peres (Lkr. Leipzig). Ein frü h-, mittelund spätneolithisches Siedlungsareal mit zahlreichen Brunnen. Ausgrabungen Sachsen 5, 30-57.

Kröger, L. (2014). Früh-und hochmittelalterliche Binnenschiffe in Mitteleuropa. Ein Überblick zum aktuellen Stand der Forschung (Raně a vrcholně středověké říční lodě ve střední Evropě. Přehled současného stavu výzkumu. Přehled výzkumů). Přehled Výzkumů 2, 91-123.

Kuitems, M., Wallace, B. L., Lindsay, C., et al. (2021). Evidence for European presence in the Americas in AD 1021. Nature [Preprint]. doi: 10.1038/s41586021-03972-8

Kuniholm, P. I. (1994). "Long Tree-Ring Chronologies for the Eastern Mediterranean Long tree-ring chronologies for the Eastern Mediterranean," in Archaeometry 94, eds S. Demirci, A. M. Ozer, and G. D. Summers (Ankara: TUBITAK), 401-409.

Kuniholm, P. I. (1996). "The Prehistoric Aegean: Dendrochronological Progress as of 1995," in Absolute Chronology: Archaeological Europe 2500-500 B.C. Acta Arch. 67, ed. K. Randsborg (Copenhagen: Munksgaard), 327-335.

Kuniholm, P. I., and Striker, C. L. (1987). Dendrochronological investigations in the Aegean and neighboring regions, 1983-1986. J. Field Archaeol. 14, 385-398. doi: $10.2307 / 530228$

Kuniholm, P. I., and Striker, C. L. (1990). Dendrochronology and the Architectural History of the Church of the Holy Apostles in Thessaloniki. Architectura Zeitschrift für Geschichte der Architektur 1-26.

Küster, H. (1996). Sieben Phasen der Nutzung mitteleuropäischer Wälder. AltThüringen 30, 55-69.

Kyncl, J. (2016). Letokruhy jako kalendár̆ $i$ záznamník: zajímavosti $z$ dendrochronologie. Prague: Grada Publishing.

Lambert, G., and Lavier, C. (1997). Datations dendrochronologiques de la station 3 de Chalain. Les sites littoraux Néolothiques de Clairvaux-les-Lacs et de Chalain (Jura) III: Chalain station 3, 3200-2900.

Lamschus, C. (1993). "Die Holzversorgung der Lüneburger Saline in Mittelalter und früher Neuzeit," in Recht und Alltag im Hanseraum, eds S. Urbanski, C. Lamschus, and J. Ellermeyer 321-333.

Lanting, J. N. (1997). Dates for origin and diffusion of the European logboat. Palaeohistoria 1997, 627-650.

Laurelut, C., Blancquaert, G., Blouet, V., Klag, T., Malrain, F., Marcigny, C., et al. (2014). Vingt-cinq ans de recherche préventive protohistorique en France du Nord: Évolution des pratiques et changements de perspectives, de l'accumulation à la synthčse des données, in: Méthodologie des recherches de terrain sur la Préhistoire récente en France. Nouveaux acquis, nouveaux outils, 1987-2012. Actes des Premičres Rencontres Nord/sud de Préhistoire Récente 2014, 419-457.

Laurent, O., Lemaire, F., and Tegel, W. (2002). Nouvelles observations sur le char hallstattien du tumulus du Champ Peupin à Ivory (Jura). Antiquités Nationales (Saint-Germain-en-Laye) 2002, 109-118.

Le Roy, M., Nicolussi, K., Deline, P., Astrade, L., Edouard, J.-L., Miramont, C., et al. (2015). Calendar-dated glacier variations in the western European Alps during the Neoglacial: the Mer de Glace record, Mont Blanc massif. Quat. Sci. Rev. 108, 1-22. doi: 10.1016/j.quascirev.2014.10.033

Lemée, C. P. P. (2006). The Renaissance Shipwrecks from Christianshavn: An archaeological and architectural study of large carvel vessels in Danish waters, 1580-1640. Oslo: Viking Ship Museum.

Leroux, G., Collas, R., Brenot, J., Desfonds, A., and Tegel, W. (2018). "Les ponts laténiens de Pont-sur-Seine (Aube) et de Visseiche (Ille-et-Vilaine): construction, datation, aspects socio-économiques," in Architectures de l'âge du
Fer - Actes du 40e colloque international de l'AFEAF, eds A. Villard-Le Tiec, Y. Menez, and P. Maguer (Rennes: Presse Universitaire).

Leuschner, H. H., and Delorme, A. (1988). Tree-ring work in Göttingen: absolute oak chronologies back to 6255 BC. Göttingen: Universität Göttingen.

Leuschner, H. H., and Sass-Klaassen, U. (2003). Subfossil oaks from bogs in NW Europe as a (dendro) archaeological archive. Peatlands-archaeological sites, archives of nature, nature conservation, wise use. Rhaden/Westf 2003, 210-216.

Leuschner, H. H., Sass-Klaassen, U., Jansma, E., Baillie, M. G. L., and Spurk, M. (2002). Subfossil European bog oaks: population dynamics and long-term growth depressions as indicators of changes in the Holocene hydro-regime and climate. Holocene 12, 695-706. doi: 10.1191/0959683602hl584rp

Levanič, T., Pignatelli, O., and Čufar, K. (2001). A regional larch chronology of trees and historical buildings from Slovenia and Northern Italy. Dendrochronologia 19, 221-229.

Liu, Y., Zhang, Z.-F., Peng, Z.-C., Ling, M.-X., Shen, C.-C., Liu, W.-G., et al. (2014). Mysterious abrupt carbon-14 increase in coral contributed by a comet. Sci. Rep. 4, 1-4. doi: 10.1038/srep03728

Ljungqvist, F. C., Tegel, W., Krusic, P. J., Seim, A., Gschwind, F. M., Haneca, K., et al. (2018). Linking European building activity with plague history. J. Arch. Sci. 98, 81-92. doi: 10.1016/j.jas.2018.08.006

Lo Cascio, E. (1994). The size of the Roman population: Beloch and the meaning of the Augustan census figures. J. Rom. Stud. 84, 23-40. doi: 10.2307/300868

Lohwasser, C. (2011). Die Holzfunde aus dem Mühlberg-Ensemble in Kempten (Allgäu).

López-Bultó, O., and Piqué Huerta, R. (2018). Wood procurement at the early Neolithic site of La Draga (Banyoles, Barcelona). J. Wetl. Archaeol. 18, 56-76.

Lozovski, V. M., Lozovskaya, O., Clemente-Conte, I., Maigrot, Y., Gyria, E. Y., Radu, V., et al. (2016). "Fishing in the late Mesolithic and early Neolithic of the Russian plain: The case of site Zamostje 2," in Lake settlement of the Mesolithic and Neolithic fisherman in Upper Volga region, eds V. Lozovski, O. Lozovskaya, and I. Zamostje 18-45.

Malzahn, E. (2011). Activity report of the Białowieża Department of the Forest research institute. From the Forest Experimental Station to the European Centre for natural Forests. Instytut Badawczy Leśnictwa Sêkocin Stary 132:83876479.

Mann, M., Kahle, H.-P., Beck, M., Bender, B. J., Spiecker, H., and Backofen, R. (2018). MICA: Multiple interval-based curve alignment. SoftwareX 7, 53-58.

Marličre, É (2002). L'outre et le tonneau dans l'Occident romain. Drémil-Lafage: Editions Mergoil.

Marshall, P., Miles, D., and Heath, D. (2004). Tree-Ring dating at Salisbury Cathedral: informing repairs. Conserv. Bull. 4, 4-5.

Martin, D. J., and Krautzberger, M. (2010). Handbuch Denkmalschutz und Denkmalpflege-einschließlich Archäologie. München: $\mathrm{CH}$ Beck.

Martinelli, N. (2014). Prehistoric pile-dwellings in northern Italy: an archaeological and dendrochronological overview. Aix-en-Provence: Direction régionale des Affaires Cuturelles de Provence-Alpes-Côte d'Azur, 69-78.

Mekhaldi, F., Muscheler, R., Adolphi, F., Aldahan, A., Beer, J., McConnell, J. R., et al. (2015). Multiradionuclide evidence for the solar origin of the cosmic-ray events of AD 774/5 and 993/4. Nat. Commun. 6, 1-8. doi: 10.1038/ncomms 9611

Menotti, F. (2015). Lakeside dwellings in the Circum Alpine region, in: The Oxford Handbook of Neolithic Europe. Oxford: OUP Oxford, 291.

Mille, P., and Rollet, P. (2020). Étude de trois grands tonneaux mis au jour à Reims/Durocortorum (Marne): le savoir-faire des tonneliers antiques. Gallia. Archéologie des Gaules 77, 123-155. doi: 10.4000/gallia.5242

Mitchell, P. (2013). Die Erweiterung von Wien unter Herzog Leopold VI. Materialhefte zur Archäol. Baden Württemberg 96, 383-394.

Miyake, F., Jull, A. T., Panyushkina, I. P., Wacker, L., Salzer, M., Baisan, C. H., et al. (2017). Large $14 \mathrm{C}$ excursion in $5480 \mathrm{BC}$ indicates an abnormal sun in the mid-Holocene. Proc. Natl. Acad. Sci. U S A. 114, 881-884. doi: 10.1073/pnas. 1613144114

Miyake, F., Nagaya, K., Masuda, K., and Nakamura, T. (2012). A signature of cosmic-ray increase in $\mathrm{AD} 774-775$ from tree rings in Japan. Nature 486, 240-242. doi: 10.1038/nature11123

Moser, D., Nelle, O., and Di Pasquale, G. (2018). Timber economy in the Roman Age: charcoal data from the key site of Herculaneum (Naples, Italy). Archaeol. Anthropol. Sci. 10, 905-921.

Muigg, B., Skiadaresis, G., Tegel, W., Herzig, F., Krusic, P. J., Schmidt, U. E., et al. (2020). Tree rings reveal signs of Europe's sustainable forest management long 
before the first historical evidence. Sci. Rep. 10, 1-11. doi: 10.1038/s41598-02078933-8

Muigg, B., Tegel, W., Rohmer, P., Schmidt, U. E., and Büntgen, U. (2018). Dendroarchaeological evidence of early medieval water mill technology. J. Arch. Sci. 93, 17-25. doi: 10.1016/j.jas.2018.02.009

Müller-Beck, H., and Boessneck, J. (1965). Seeberg, Burgäschisee-Süd. 5. Stämpfli: Holzgeräte und Holzbearbeitung.

Myhr, K., Thun, T., and Hytteborn, H. (2007). Dendrochronological dating of wooden artefacts using photography. Norwegian Archaeol. Rev. 40, 179-186.

Naumov, G. (2020). "Neolithic wetland and lakeside settlements in the Balkans," in Settling waterscapes in Europe. The archaeology of Neolithic and Bronze Age piledwellings, eds A. Hafner, E. Dolbunova, A. Mazurkevic, E. Pranckenaite, and M. Hinz (Heidelberg: Propyläum), 111-134.

Nayling, N., and Susperregi, J. (2014). Iberian Dendrochronology and the Newport Medieval Ship. Int. J. Naut. Archaeol. 43, 279-291.

Nechita, C., Eggertsson, O., Badea, O. N., and Popa, I. (2018). A 781-year oak tree-ring chronology for the Middle Ages archaeological dating in Maramureş (Eastern Europe). Dendrochronologia 52, 105-112. doi: 10.1016/j.dendro.2018. 10.006

Nelle, O., Dreibrodt, S., and Dannath, Y. (2010). Combining pollen and charcoal: evaluating Holocene vegetation composition and dynamics. J. Arch. Sci. 37, 2126-2135. doi: 10.1890/14-0209.1

Neweklowsky, E. (1952). Die Schiffahrt und Flößerei im Raume der oberen Donau. Oberösterreichischer: Landesverlag.

Neweklowsky, E. (1959). Die Flößerei auf den alpinen Nebenflüssen der oberen Donau, in: Jahrbuch des. Innsbruck: Österreichischen Alpenvereins, 131-138.

Neyses-Eiden, M. (1998). Erste römerzeitliche Tannenchronologie für die Nordwest-Provinzen. Trierer Zeitschrift-Archäologie und Kunst des Trierer Landes und seiner Nachbargebiete 61, 137-154.

Nicolussi, K. (1998a). "Dendrochronological datings of the building history of a Roman alpine road near Lermoos (Austria)," in Dendrochronology and Environmental Trends. Proceedings of the International Conference Eurodendro '98, eds V. Stravinskiene and R. Juknys (Kaunas: Eurodendro), 56-66.

Nicolussi, K. (1998b). "Die Bauhölzer der Via Claudia Augusta bei Lermoos (Tirol)," in Via Claudia - Neue Forschungen, ed. E. Walde (Innsbruck: Instituts für Hochgebirgsforschung), 113-145.

Nicolussi, K. (2009). “Alpine Dendrochronologie-Untersuchungen zur Kenntnis der holozänen Umwelt-und Klimaentwicklung," in Klimawandel in Österreich. Alpine Space - man \& environment 6, eds R. Schmidt, C. Matulla, and R. Psenner (Innsbruck: University Press), 41-54.

Nicolussi, K., and Patzelt, G. (2000). Abhandlungen-Untersuchungen zur holozänen Gletscherentwicklung von Pasterze und Gepatschferner (Ostalpen). Gletsch.kd. Glazialgeol. 36, 1-87.

Nicolussi, K., Kaufmann, M., Melvin, T. M., van der Plicht, J., Schießling, P., and Thurner, A. (2009). A 9111 year long conifer tree-ring chronology for the European Alps: a base for environmental and climatic investigations. Holocene 19, 909-920. doi: 10.1177/0959683609336565

Nicolussi, K., Kaufmann, M., Patzelt, G., and Thurner, A. (2005). Holocene treeline variability in the Kauner Valley. Veg. Hist. Archaeobot. 14, 221-234.

Nicolussi, K., Matuschik, I., and Tegel, W. (2013). Klimavariabilität und Siedlungsdynamik am Beispiel der Feuchtbodensiedlungen im Raum Oberschwaben, Bodensee und Nordostschweiz 4400-3400 BC. DendroChronologie-Typologie-Ökologie. Festschrift für André Billamboz zum 65 . Geburtstag 65, 69-86.

Nicolussi, K., Spötl, C., Thurner, A., and Reimer, P. J. (2015). Precise radiocarbon dating of the giant Köfels landslide (Eastern Alps, Austria). Geomorphology 243, 87-91. doi: 10.1016/j.geomorph.2015.05.001

O'hare, P., Mekhaldi, F., Adolphi, F., Raisbeck, G., Aldahan, A., Anderberg, E., et al. (2019). Multiradionuclide evidence for an extreme solar proton event around 2,610 BP ( 660 BC). Proc. Natl. Acad. Sci. U S A. 116, 59615966. doi: $10.1073 /$ pnas. 1815725116

Oberhänsli, M., Seifert, M., Bleicher, N., Schoch, W. H., Reitmaier-Naef, L., Turck, R., et al. (2019). "Dendrochronological dating of charcoal from high-altitude prehistoric copper mining and smelting sites in the Oberhalbstein Valley (Grisons, Switzerland)," in New Results and Perspectives on Prehistoric Copper Production, (Rahden-Westfalen: Verlag Marie Leidorf), 245-260.
Panayotov, M., Bebi, P., Trouet, V., and Yurukov, S. (2010). Climate signal in tree-ring chronologies of Pinus peuce and Pinus heldreichii from the Pirin Mountains in Bulgaria. Trees 24, 479-490.

Park, J., Southon, J., Fahrni, S., Creasman, P. P., and Mewaldt, R. (2017). Relationship between solar activity and $\Delta 14 \mathrm{C}$ peaks in AD 775. Radiocarbon 59, 1147-1156. doi: 10.1017/rdc.2017.59

Parzinger, H. (2006). Die frühen Völker Eurasiens: vom Neolithikum bis zum Mittelalter. CH Beck: Munich.

Pearson, K. (1895). Note on regression and inheritance in the case of two parents. Proc. R. Soc. Lond. 58, 240-242. doi: 10.1098/rspl.1895.0041

Pedersen, N. B., Matthiesen, H., Blanchette, R. A., Alfredsen, G., Held, B. W., Westergaard-Nielsen, A., et al. (2020). Fungal attack on archaeological wooden artefacts in the Arctic-implications in a changing climate. Sci. Rep. 10:14577. doi: 10.1038/s41598-020-71518-5

Pickvance, C. (2012). Medieval domed chests in Kent: a contribution to a national and international study. Reg. Furnit. 26, 105-147.

Pickvance, C. (2015). The slow arrival of renaissance influence on English furniture: a study of the 1519 Silkstede. Reg. Furnit. 29, 101-130.

Pilcher, J. R. (1976). A statistical oak chronology from the North of Ireland. Belfast: Queen's University Belfast, 0041-2198.

Pilcher, J. R., Baillie, M. G. L., Schmidt, B., and Becker, B. (1984). A 7,272-year tree-ring chronology for western Europe. Nature 312, 150-152.

Pilcher, J. R., Hillam, J., Baillie, M. G. L., and Pearson, G. W. (1977). A long sub-fossil oak tree-ring chronology from the north of Ireland. New Phytol. 713-729.

Polosmak, N. V., and Seifert, M. (1996). Menschen aus dem Eis Sibiriens. Neuentdeckte Hügelgräber (Kurgane) im Permafrost des Altai. Antike Welt 27, 87-108.

Pomey, P. (1996). Navigation and ships in the age of Greek colonization. Greek: The Western Greeks, 133-140.

Popa, I., and Kern, Z. (2009). Long-term summer temperature reconstruction inferred from tree-ring records from the Eastern Carpathians. Clim. Dyn. 32, 1107-1117.

Pranckënaitë, E., Dolbunova, E., and Mazurkevich, A. (2021). Pile Dwellings in the Circum-Baltic Area. Doc. Praehist. 48, 102-116. doi: 10.4312/dp.48.14

Prokop, O., Kolář, T., Büntgen, U., Kyncl, J., Kyncl, T., Bošel’a, M., et al. (2016). On the palaeoclimatic potential of a millennium-long oak ring width chronology from Slovakia. Dendrochronologia 40, 93-101.

Pukiene, R. (2003). Sub-fossil oak timbers from the Mid Holocene as an evidence for Lithuanian forest history. Balt. For. 9, 71-75.

Reimer, P. J., Austin, W. E. N., Bard, E., Bayliss, A., Blackwell, P. G., Ramsey, C. B., et al. (2020). The IntCal20 Northern Hemisphere radiocarbon age calibration curve (0-55 cal kBP). Radiocarbon 62, 725-757. doi: 10.1017/rdc. 2020.41

Reinig, F., Nievergelt, D., Esper, J., Friedrich, M., Helle, G., Hellmann, L., et al. (2018). New tree-ring evidence for the Late Glacial period from the northern pre-Alps in eastern Switzerland. Quat. Sci. Rev. 186, 215-224.

Reinig, F., Sookdeo, A., Esper, J., Friedrich, M., Guidobaldi, G., Helle, G., et al. (2020). Illuminating IntCal during the Younger Dryas. Radiocarbon 62, 883889. doi: $10.1017 /$ rdc. 2020.15

Reinig, F., Wacker, L., Jöris, O., Oppenheimer, C., Guidobaldi, G., Nievergelt, D., et al. (2021). Precise date for the Laacher See eruption synchronizes the Younger Dryas. Nature 595, 66-69. doi: 10.1038/s41586-021-03608-x

Reschreiter, H., and Kowarik, K. (2019). Bronze Age Mining in Hallstatt. A New Picture of Everyday Life in the Salt Mines and Beyond. Archaeol. Austriaca 103, 99-136.

Reynolds, P. (1985). Iron-Age-Farm. Zur Rekonstruktion der Häuser von Biskupin. 9-19.

Rinn, F. (2003). TSAP-Win. Time series analysis and presentation for dendrochronology and 409 related applications. User reference.

Ritchie, H., and Roser, M. (2017). Fossil fuels. Our world in data. https:// ourworldindata.org/fossil-fuels.

Robben, F. (2009). Mittelalterliche Fässer aus der Hansestadt Greifswald: Ein Beitrag zur Alltags-und'Wirts chaftsgeschichte. Bodendenkmalpflege Mecklenburg Vorpommern 56, 157-189.

Rohmer, P., and Tegel, W. (1999). Aménagements en bois dans un ancien lit de la Seille (Metz, Boulevard Paixhans). Etude d'un ouvrage en milieu fluvial et aspects dendroécologiques du bois d'śuvre 6, 21-25. 
Roibu, C.-C., Ważny, T., Crivellaro, A., Mursa, A., Chiriloaei, F., ştirbu, M.-I., et al. (2021). The Suceava oak chronology: A new 804 years long tree-ring chronology bridging the gap between central and south Europe. Dendrochronologia 2021:125856. doi: 10.1016/j.dendro.2021.125856

Rump, H. H. (2011). Bruno Huber (1899-1969)-Botaniker und Dendrochronologe. Ulmer.

Rybníček, M., Chlup, T., Kalábek, M., Kalábková, P., Kočár, P., Kyncl, T., et al. (2018). New dendroarchaeological evidence of water well constructions reveals advanced Early Neolithic craftsman skills. Dendrochronologia 50, 98-104. doi: 10.1016/j.dendro.2018.06.003

Rybníček, M., Kočár, P., Muigg, B., Peška, J., Sedláček, R., Tegel, W., et al. (2020). World's oldest dendrochronologically dated archaeological wood construction. J. Arch. Sci. 115:105082. doi: 10.1016/j.jas.2020.105082

Rybníček, M., Vavrčík, H., and Hubený, R. (2006). Determination of the number of sapwood annual rings in oak in the region of southern Moravia. J. For. Sci. 52, 141-146. doi: 10.17221/4496-jfs

Rynne, C. (2015). The technical development of the horizontal water-wheel in the first millennium AD: some recent archaeological insights from Ireland. Int. J. Hist. Eng. 85, 70-93. doi: 10.1179/1758120614z.00000 000055

Rzepecki, A., Neyses-Eiden, M., Frank, T., Diethelm, B., Herzig, F., and Tegel, W. (2019). Missing link in Late Antiquity? A critical examination of Hollstein's Central European Oak Chronology. Dendrochronologia 54, 20-28.

Saleh, D., Chen, J., Leple, J.-C., Leroy, T., Truffaut, L., Dencausse, B., et al. (2021). Genome-wide evolutionary response of European oaks since the Little Ice Age. bioRxiv.

Sangüesa-Barreda, G., Camarero, J. J., Esper, J., Galván, J. D., and Büntgen, U. (2018). A millennium-long perspective on high-elevation pine recruitment in the Spanish central Pyrenees. Can. J. For. Res. 48, 1108-1113. doi: 10.1139/cjfr2018-0025

San-Miguel-Ayanz, J., Rigo, D., de, Caudullo, G., Durrant, T. H., and Mauri, A. (2016). European atlas of forest tree species. Publications Office of the European Union.

Schadwinkel, H.-T., Heine, G., and Gerner, M. (1986). Das Werkzeug des Zimmermanns: Mit einer Einführung "Das Zimmerhandwerk". Schäfer.

Scharnweber, T., Heußner, K.-U., Smiljanic, M., Heinrich, I., van der MaatenTheunissen, M., van der Maaten, E., et al. (2019). Removing the no-analogue bias in modern accelerated tree growth leads to stronger medieval drought. Sci. Rep. 9, 1-10. doi: 10.1038/s41598-019-39040-5

Schlichtherle, H. (2010). als die ersten räder rollten... räder der jungsteinzeit aus dem Olzreuter Ried bei Bad Schussenried. Denkmalpflege Baden Württemberg Nachrichtenblatt der Landesdenkmalpflege 39, 140-144.

Schmidt, B., Köhren-Jansen, H., and Freckmann, K. (1990). Kleine Hausgeschichte der Mosellandschaft. Rheinland-Verlag.

Schmidt, B., Köhren-Jansen, H., Freckmann, K., and Gechter, M. (2001). Auf den Spuren alter Häuser: Jahrringdatierung und Bauweise; Lohmar im Bergischen Land. Siebengebirge: Jonas-Verlag.

Schmidt, U. E. (2002). Der Wald in Deutschland im 18. und 19. Jahrhundert: das Problem der Ressourcenknappheit dargestellt am Beispiel der Waldressourcenknappheit in Deutschland im 18. und 19. Jahrhundert: eine historisch-politische Analyse. Saarbrücken: Conte.

Schoch, W., Heller, I., Schweingruber, F. H., and Kienast, F. (2004). Wood anatomy of central European Species. Available online at: www.woodanatomy.ch

Schweingruber, F. H. (1976). Prähistorisches Holz: die Bedeutung von Holzfunden aus Mitteleuropa für die Lösung archäologischer und vegetationskundlicher Probleme. Bern: Haupt.

Schweingruber, F. H. (1978). Microscopic Wood Anatomy: Structural variability of stems and twigs in recent and subfossil woods from Central Europe. Zürich: Swiss Federal Institute of Forestry Research.

Schweingruber, F. H. (1983). Der Jahrring: Standort, Methodik, Zeit und Klima in der Dendrochronologie. Bern: P. Haupt.

Schweingruber, F. H. (1990). Anatomie europäischer Hölzer/Anatomy of European woods: Ein Atlas zur Bestimmung europäischer Baum-, Strauch-und Zwergstrauchhölzer. Bern: Verlag Paul Haupt.

Schweingruber, F. H. (1996). Tree rings and environment: dendroecology. Bern: Paul Haupt AG Bern.

Schweingruber, F. H. (2007). Wood structure and environment. Berlin: Springer Science \& Business Media.
Schweingruber, F. H. (2011). Anatomie europäischer Hölzer - Anatomy of European Woods: ein Atlas zur Bestimmung europäischer Baum-, Strauch- und Zwergstrauchhölzer - An Atlas for the identification of european trees. Remagen: Verlag Kessel.

Seftigen, K., Linderholm, H. W., Drobyshev, I., and Niklasson, M. (2013). Reconstructed drought variability in southeastern Sweden since the 1650s. Int. J. Climatol. 33, 2449-2458. doi: 10.1002/joc.3592

Seifert, M. (2018). Zur Chronologie und Typologie der Wohnbauten Graubündens im Zeitraum von 1350 bis 1850 In: Die Schweiz von 1350 bis 1850 im Spiegel archäologischer Quellen. Basel: Verlag Archäologie Schweiz, $115-128$.

Seiller, M., Lohrum, B., Tegel, W., and Werlé, M. (2014). Des châssis de fenêtre en bois du XIe sičcle et de nouvelles observations sur les parties orientales de l'ancienne église collégiale de Surbourg. Cahiers alsaciens d'archeologie d'art et d'histoire 57-74.

Seim, A., Büntgen, U., Fonti, P., Haska, H., Herzig, F., Tegel, W., et al. (2012). Climate sensitivity of a millennium-long pine chronology from Albania. Clim. Res. 51, 217-228.

Seim, A., Linscott, K., Heussner, K.-U., Bonde, N., Baittinger, C., Stornes, J. M., et al. (2015). Diverse construction types and local timber sources characterize early medieval church roofs in southwestern Sweden. Dendrochronologia 35, 39-50. doi: 10.1016/j.dendro.2015.06.001

Shindo, L., and Claude, S. (2019). Buildings and wood trade in Aix-en-Provence (South of France) during the Modern period. Dendrochronologia 54, 29-36. doi: 10.1016/j.dendro.2019.02.003

Shindo, L., and Giraud, E. (2021). Well-designed mountain houses feature the only dated Pinus sylvestris type timbers in the southern French Alps. Dendrochronologia 67:125833. doi: 10.1016/j.dendro.2021.125833

Shindo, L., Belingard, C., Edouard, J.-L., and Saulnier, M. (2017). A long-term tree-ring chronology over 796 years for silver fir (Abies alba Mill.) in southern France. Ann. For. Sci. 74, 1-5.

Skiadaresis, G., Muigg, B., and Tegel, W. (2021). Historical Forest Management Practices Influence Tree-Ring Based Climate Reconstructions. Front. Ecol. Evol. 9:727651. doi: 10.3389/fevo.2021.727651

Sochová, I., Koláŕ, T., and Rybníček, M. (2021). A Review of Oak Dendrochronology in Eastern Europe. Tree Ring Res. 77, 10-19.

Sohar, K., Vitas, A., and Läänelaid, A. (2012). Sapwood estimates of pedunculate oak (Quercus robur L.) in eastern Baltic. Dendrochronologia 30, 49-56. doi: 10.1016/j.dendro.2011.08.001

Solomina, O. N., Bradley, R. S., Jomelli, V., Geirsdottir, A., Kaufman, D. S., Koch, J., et al. (2016). Glacier fluctuations during the past 2000 years. Quat. Sci. Rev. 149, 61-90.

Solomina, O., and Matskovsky, V. (2021). Dendrochronology in European Russia in the early 21st century: state-of-the-art. Front. Ecol. Evolut. 2021:661. doi: $10.3389 /$ fevo.2021.738199

Spain, R. (2008). Mechanical Analysis of vertical-wheeled watr-mills. BAR Int. Ser. 2008:1786.

Speer, J. H. (2010). Fundamentals of tree-ring research. Arizona: University of Arizona Press.

Spurk, M., Friedrich, M., Hofmann, J., Remmele, S., Frenzel, B., Leuschner, H. H., et al. (1998). Revisions and extension of the Hohenheim oak and pine chronologies: new evidence about the timing of the Younger Dryas/Preboreal transition. Radiocarbon 40, 1107-1116. doi: 10.1017/s0033822200019159

Stallings, W. S., and Schulman, E. (1937). Some early papers on tree-rings. 41-2198. Stelzner, J., and Million, S. (2015). X-ray computed tomography for the anatomical and dendrochronological analysis of archaeological wood. J. Arch. Sci. 55, 188-196. doi: 10.1016/j.jas.2014.12.015

Stocker, T. (2014). Climate change 2013: the physical science basis: Working Group I contribution to the Fifth assessment report of the Intergovernmental Panel on Climate Change. Cambridge: Cambridge university press.

Stoeckhardt, J. A. (1871). Untersuchungen uber die schadliche Einwirkung des Hutten-und Steinkohlenrauches auf das Wachsthum der Pflanzen, insbesondere der Fichte und Tanne. Tharandter forstliches Jahrbuch 21, 218254.

Susperregi, J., Telleria, I., Urteaga, M., and Jansma, E. (2017). The Basque farmhouses of Zelaa and Maiz Goena: New dendrochronology-based findings about the evolution of the built heritage in the northern Iberian Peninsula. J. Arch. Sci. Rep. 11, 695-708. doi: 10.1016/j.jasrep.2016.12.035 
Szymczak, S., Hetzer, T., Bräuning, A., Joachimski, M. M., Leuschner, H.-H., and Kuhlemann, J. (2014). Combining wood anatomy and stable isotope variations in a 600-year multi-parameter climate reconstruction from Corsican black pine. Quat. Sci. Rev. 101, 146-158. doi: 10.1016/j.quascirev.2014.07.010

Tamerl, I. (2010). Das Holzfass in der römischen Antike. Bozen: StudienVerlag.

Tarrús, J. (2018). La Draga (Banyoles, Catalonia), an Early Neolithic Lakeside Village in Mediterranean Europe. Catalan Hist. Rev. 1, 17-33. doi: 10.2436/20. 1000.01 .2

Tegel, W., and Brun, O. (2008). "Premiers résultats des analyses dendrochronologiques relatives aux boulins de construction. Nouveaux regards sur la cathédrale de Reims. Sous la direction de Bruno Decrock et Patrick Demouy," in Actes du colloque international des 1er et 2 octobre 2004, ed. D. Guéniot (Langres: Dominique Gueěniot), 29-40.

Tegel, W., and Croutsch, C. (2016). Wood anatomy and construction technique of Late Bronze Age rural cartwheels. J. Arch. Sci. Rep. 7, 123-128. doi: 10.1016/j. jasrep.2016.04.001

Tegel, W., and Muigg, B. (2015). Dendrochronologische Datierung der Holzklammern aus der "Heidenmauer" auf dem Odilienberg (Ottrott, Elsass). Zeitschrift für Archäologie des Mittelalters 29-37.

Tegel, W., Elburg, R., Hakelberg, D., Stäuble, H., and Büntgen, U. (2012). Early Neolithic water wells reveal the world's oldest wood architecture. PLoS One 7:e51374. doi: 10.1371/journal.pone.0051374

Tegel, W., Muigg, B., and Büntgen, U. (2016a). The wood of Merovingian weaponry. J. Arch. Sci. 65, 148-153.

Tegel, W., Seim, A., Hakelberg, D., Hoffmann, S., Panev, M., Westphal, T., et al. (2014). A recent growth increase of European beech (Fagus sylvatica L.) at its Mediterranean distribution limit contradicts drought stress. Eur. J. For. Res. 133, 61-71. doi: 10.1007/s10342-013-0737-7

Tegel, W., Seim, A., Skiadaresis, G., Ljungqvist, F. C., Kahle, H.-P., Land, A., et al. (2020). Higher groundwater levels in western Europe characterize warm periods in the Common Era. Sci. Rep. 10, 1-8. doi: 10.1038/s41598-020-73 383-8

Tegel, W., Vanmoerkerke, J., and Büntgen, U. (2010). Updating historical treering records for climate reconstruction. Quat. Sci. Rev. 29, 1957-1959. doi: 10.1016/j.quascirev.2010.05.018

Tegel, W., Vanmoerkerke, J., Hakelberg, D., and Büntgen, U. (2016b). "Des cernes de bois à l'histoire de la conjoncture de la construction et à l'évolution de la pluviomé trie en Gaule du Nord entre 500 BC et 500 AD," in Évolution des societes gauloises du Second âge du Fer, entre mutations internes et influences externes, eds G. Blancquaert and F. Malrain (Amiens: Actes du 38 e colloque de l'AFEAF. Revue Archéologique de Picardie $n^{\circ}$ spécial 30), 639-653.

Tegtmeier, U. (2016). Holzobjekte und Holzhandwerk im römischen Köln: Archäologie Nord-Süd Stadtbahn Köln. Köln: Römisch Germanisches Museum.

Teigelake, U. (1998). Untersuchungen zum "keltischen" Schiffbau. Kritische Betrachtungen der Definition einer Schiffbautradition 6-19.

Thieme, H. (1997). Lower Palaeolithic hunting spears from Germany. Nature 385, 807-810. doi: 10.1038/385807a0

Thomsen, C. J. (1836). Ledetraad til nordisk oldkyndighed. Copenhagen (English editon 1848, A Guide to Northern Antiquities). Copenhagen: Northern Antiquities.

Thun, T., and Svarva, H. L. (2017). Tree-ring growth shows that the significant population decline in Norway began before the Black Death. Amsterdam: Dendrochronologia.

Tinner, W., and Lotter, A. F. (2006). Holocene expansions of Fagus silvatica and Abies alba in Central Europe: where are we after eight decades of debate? Quat. Sci. Rev. 25, 526-549.

Tinner, W., Conedera, M., Ammann, B., and Lotter, A. F. (2005). Fire ecology north and south of the Alps since the last ice age. Holocene 15, 1214-1226. doi: 10.1191/0959683605hl892rp

Topham, J. (2003). A dendrochronological study of violins made by Antonio Stradivari. J. Am. Music. Instrum. Soc. 29:72. doi: 10.1111/j.1469-8137.2008. 02524.x

Topham, J., and McCormick, D. (1998). A dendrochronological investigation of British stringed instruments of the violin family. J. Arch. Sci. 25, 11491157.

Ulbert, G. (1959). Römische Holzfässer aus Regensburg. Munich: Beck.
Usoskin, I. G., Kromer, B., Ludlow, F., Beer, J., Friedrich, M., Kovaltsov, G. A., et al. (2013). The AD775 cosmic event revisited: the Sun is to blame. Astron. Astrophys. 552:L3.

van den Bulcke, J., Wernersson, E. L. G., Dierick, M., van Loo, D., Masschaele, B., Brabant, L., et al. (2014). 3D tree-ring analysis using helical X-ray tomography. Dendrochronologia 32, 39-46.

van Es, W. A. (1972). Dendrochronologische Untersuchungen von Daubenbrunnen aus der frühmittelalterlichen Siedlung Dorestad, Holland. Kunde (die). Mitteilungen des Niedersächsischen Landesverein für Urgeschichte 23, 221-226.

van Es, W. A., and Verwers, W. J. H. (1980). Excavations at Dorestad 1. Harbour Hoogstraat I. Nederlandse Oudheden 9, 262-285.

van Lanen, R. J., Jansma, E., van Doesburg, J., and Groenewoudt, B. J. (2016). Roman and early-medieval long-distance transport routes in northwestern Europe: modelling frequent-travel zones using a dendroarchaeological approach. J. Arch. Sci. 73, 120-137.

Velušček, A., and Čufar, K. (2009). Prehistoric wooden wheel with an axle from pile-dwelling Stare gmajne at the Ljubljansko barje. Založba ZRC: Inštitut za arheologijo ZRC SAZU.

Vitas, A. (2017). The First Evidence of Subfossil Oak Wood from Riverine Sediments in Lithuania: A Dendrochronological Investigation. Balt. For. 23, 471-476.

Vitas, A. (2020). Medieval oak chronology from Klaipëda, Lithuania. Dendrochronologia 64:125760. doi: 10.1016/j.dendro.2020.125760

Wagenführ, R. (1966). “Anatomie des Holzes: Unter besonderer Berücksichtigung der Holztechnik,” in Mit 160 Bildern, 66 Tabellen und einem Bildanhang (313 Mikrofotos), (Leipzig: Fachbuchverlag).

Wagner, S., Lagane, F., Seguin-Orlando, A., Schubert, M., Leroy, T., Guichoux, E., et al. (2018). High-Throughput DNA sequencing of ancient wood. Mol. Ecol. 27, 1138-1154. doi: $10.1111 / \mathrm{mec} .14514$

Warde, P. (2006). Ecology, economy and state formation in early modern Germany. Cambridge, MA: Cambridge university press.

Warde, P. (2018). The Invention of sustainability: Nature and destiny, c. 1500-1870. Cambridge, MA: Cambridge university press.

Wazny, T. (1992). "Historical timber trade and its implications on dendrochronological dating," in Tree-Rings and Environment Lundqua Report 34.

Wazny, T. (2002). Baltic timber in Western Europe-an exciting dendrochronological question. Dendrochronologia 20, 313-320. doi: 10.1078/1125-7865-00024

Wazny, T., and Eckstein, D. (1991). The dendrochronological signal of oak (Quercus spp.) in Poland. Dendrochronologia 9, 35-49.

Werlé, M. (2017). Trois maisons de Strasbourg construites sur les cendres de l'incendie de Strasbourg de 1397. Cahiers alsaciens d'archeologie, d'art et d'histoire, 5 .

Westphal, T. (2002). Frühe Stadtentwicklung zwischen mittlerer Elbe und unterer Oder zwischen ca. 1150-1300 aufgrund der dendrochronologischen Daten: mit einem Beitrag zur dendrochronologischen Untersuchung frühmittelalterlicher Burgwälle der Niederlausitz; Ergebnisse und Materialien zum DFG-Projekt" Germanen-Slawen-Deutsche“. Habelt.

Wikander, Ö (1984). Exploitation of water-power or technological stagnation?: a reappraisal of the productive forces in the Roman empire. Gleerup.

Willerding, U. (1996). Zur Waldnutzung vom Neolithikum bis in die Neuzeit. Alt-Thüringen 30, 13-53.

Wilson, R. J. S., Luckman, B. H., and Esper, J. (2005). A 500 year dendroclimatic reconstruction of spring-summer precipitation from the lower Bavarian Forest region, Germany. Int. J. Climatol. 25, 611-630.

Wilson, R., Wilson, D., Rydval, M., Crone, A., Büntgen, U., Clark, S., et al. (2017). Facilitating tree-ring dating of historic conifer timbers using Blue Intensity. J. Arch. Sci. 78, 99-111.

Wimmer, R. (2001). Arthur Freiherr von Seckendorff-Gudent and the early history of tree-ring crossdating. Dendrochronologia 19, 153-158.

Wimmer, R. (2002). Wood anatomical features in tree-rings as indicators of environmental change. Dendrochronologia 20, 21-36. doi: 10.1093/treephys/ tpy061

Withalm, B. (2018). Holz - das vergessene Dokument. Zur Bedeutung des Baustoffs Holz im historischen Baugeschehen am Beispiel der mittelalterlichen Wohnstube. Stuttgart: Fraunhofer IRB. 
Wrobel, S., Holst, J. C., and Eckstein, D. (1993). Holz im HausbauDendrochronologisch-bauhistorische Reihenuntersuchungen

zum Hausbau des 13.-17. Jahrhunderts in Lübeck. Wege zur Erforschung stadtischer Häuser und Höfe. Neumünster: K. Wachholtz Verlag, 183-249.

Zunde, M. (2011). "New dendrochronological and historical evidence of longdistance floating of timbers to Riga," in Tree-Rings, Art and Archaeology (Scientia Artis ed., Vol. 7), ed. P. Fraiture (Brussels: Royal Institute for Cultural Heritage / Koninklijk Instituut voor het Kunstpatrimonium).

Conflict of Interest: The authors declare that the research was conducted in the absence of any commercial or financial relationships that could be construed as a potential conflict of interest.
Publisher's Note: All claims expressed in this article are solely those of the authors and do not necessarily represent those of their affiliated organizations, or those of the publisher, the editors and the reviewers. Any product that may be evaluated in this article, or claim that may be made by its manufacturer, is not guaranteed or endorsed by the publisher.

Copyright (๑ 2022 Tegel, Muigg, Skiadaresis, Vanmoerkerke and Seim. This is an open-access article distributed under the terms of the Creative Commons Attribution License (CC BY). The use, distribution or reproduction in other forums is permitted, provided the original author(s) and the copyright owner(s) are credited and that the original publication in this journal is cited, in accordance with accepted academic practice. No use, distribution or reproduction is permitted which does not comply with these terms. 